\title{
LA APROBACIÓN CIVIL DEL COLEGIO DE MISIONEROS DEL PADRE CLARET: 1859 Y 1867, CONFORME AL ARTÍCULO 29 DEL CONCORDATO DE 1851
}

\author{
POR \\ Eutimio SASTRE SANTOS \\ Universidad Urbaniana, Roma
}

\section{Resumen}

El artículo 29 del Concordato entre España y la Santa Sede del 1851 fue uno de los más controvertidos. Durante los años de vigencia del Concordato, que pueden extenderse hasta el 1953, no se fijó su clara interpretación y aplicación. El presente trabajo muestra la interpretación que de él hizo el gobierno liberal de Isabel II. En conformidad con el dicho artículo 29, la unión liberal de ODonnell aprobó en 1859 los Estatutos del Colegio de Misioneros del Padre Claret, y el gobiemo de Narváez en 1867 concedió a sus miembros la exención de quintas; de ambos actos necesitaba el Colegio de Misioneros para afïrmarse. La investigación realizada estriba sobre los papeles del archivo del Ministerio de Justicia. Se añade un apéndice bibliográfico sobre el Concordato del 1851 y su artículo 29.

\begin{abstract}
The article 29 of the Concordat between Spain and the Holy See, signed in the year 1851, during the time of its application did not find clear interpretation. The author in the present paper shows how the liberal goverment used it to approve the Missionary Congregation of Mons. Claret in 1859 and the exemption of its members from military service in 1867. The paper is based in the archival holdings of the Ministry of Justice. A collection of special bibliography has been added to the Concordat of 1851 and its article 29 .
\end{abstract}




\section{INTRODUCCION}

I. Origen de este trabajo y explicación del título

El habitual pretexto del aniversario ampara estas páginas. El 16 de julio de 1849, fiesta del Carmen y de la Santa Cruz, el padre Claret fundó en Vic (Barcelona) la Congregación de Misioneros Hijos del Inmaculado Corazón de María; el presente año de 1999 festeja su ciento cincuenta aniversario. Cierto, que la investigación histórica no debería citarse con los aniversarios. No obstante, la ocasion festiva tolera el estudio de temas particulares, y aún fuerza el balance del estado de la cuestión de los generales. Y en la ausencia de auténticos proyectos de investigación bienvenidos sean los aniversarios.

Dos actos del gobierno liberal legalizaron la Congregación de Misioneros del padre Claret, confesor de la reina Isabel II: primero en 1859, la Unión Liberal de O'Donnell aprob6 sus Estatutos, y después en 1867, de Narváez obtuvo la exención de quintas. Grávido de sentido espiritual está su título completo: Hijos del Inmaculado Corazón de María. Título, que el gobiemo abreviaba en: Colegio de misioneros fundado por Mons. Claret. Y sus enemigos también ${ }^{1}$. Y aún el obispo de Huesca lo equivocó por Oblatos ${ }^{2}$.

La Congregación de Mons. Claret lo es masculina secular, es decir, que no es regular ${ }^{3}$; una gran ventaja, pues la mentalidad liberal aborrece los regulares masculinos; los tolera, si confinados en Ultramar. Más tolerante se muestra con los seculares, y siempre en los términos del Concordato del 1851. Mentalidad y leyes liberales, impotentes frente a la resistencia numantina de los institutos femeninos: regulares y seculares ${ }^{4}$. Congregación secular y de sacerdotes misioneros en ayuda de obispos y párrocos, y abierta a Ultramar; circunstancia, que justificó su aprobación en conformidad con el art. 29 del Concordato de 1851.

El avisado lector, interesado en la política religiosa isabelina, y en la posterior liberal, habrá advertido la importancia del tema abordado. No se confunde con la anécdota particular. Engrosa la historia general. Su estudio encausa la posición teórica y práctica de los liberales ante el ambiguo art. 29 del Concordato. Crecido interés histórico, que supera también la ocasión de un aniversario.

1 A. DE FUNES, - E. DE LuSTANo, Los neos en calzoncillos, Madrid 1868, 129-130, «El P. Claret fundó tres colegios de misioneros, uno en Segovia, otto en Sevilla y otro en'Vich con las sumas que sacaba de Palacio»; los redactores de La Iberia descuidaron su información sobre el Padre Claret; el colegio sevillano es pura fantasía.

2 Apendice documental, n. 25.

3 Infra II. La cuestión juridica.. 1. Los supuestos jurídicos..

4 COMISION DE ESTADISTICA GENERAL DEL ReINO, Anuario estadistico de Espafia correspondiente a 1859 y 1860 .., Madrid 1860, 77, religiosas exclaustradas en 1859, que perciben del tesoro, son 412; en Badajoz 103, en Segovia 1, en Burgos 0.

Hispania, del Mediterráneo al Atlántico Hispania Sacra 51 (1999) 


\section{Objeto y límites}

El título del trabajo encubre y sugiere el variado entomo de este acto de la política isabelina. Variedad de temas, que no desdibujan el objeto: documentar y razonar el porqué y el cómo de la existencia legal, que los gobiernos isabelinos otorgaron al Colegio de Misioneros de Mons. Claret. Material es el primer tropiezo y límite; el Apéndice documental, imprescindible, ya se ha llevado un buen número de páginas; y mermadas quedan las probanzas de la exención de quintas. Los límites materiales de una revista se aceptan, no se discuten.

¿Cuántas de las circunstancias, que califican la legalización isabelina de este Colegio de Misioneros, sería necesario puntualizar para mejor razonarla y entenderla? Si la exención de quintas ha sufrido la merma de su documentación, se excusa su estudio minucioso; basta su presencia. De capital importancia el Concordato del 1851, base legal de la aprobación, sin que sirva de ocasión para disertar sobre él. Y, aunque muy discutida fue la inteligencia teórica de la «tercera orden» en su art. 29 , no será necesario historiar las opiniones enfrentadas desde el 1851 hasta el 1904. Entre otras razones porque el Gobierno dió la suya en mayo del 1859 , y sobre ella estribó la aprobación del Colegio de Misioneros de Mons. Claret. Obligada la referencia a la mentalidad, que estrecha o ensancha la interpretación de la «tercera orden». Empero, ¿qué se entiende por la «acción moralizadora» de una casa-misión, de un qolegio de misioneros? Tema superlativo, cuyas vertientes, civil y eclesiástica, no es posible ignorar; y también sólo se adviertens. Y fuera de nuestro interés quedan cuantos misioneros apostólicos han sido, padre Claret incluido.

Amplio se describe el entorno jurídico, político, de mentalidad, que enmarcó esta decisión política isabelina. Notado, nos reducimos a razonar la situación legal de una congregación secular, «no concordada»: el Colegio de Misioneros de Mons. Claret. Un caso práctico de cómo se resolvió la duda de la «tercera orden». Excúsanse otras aprobaciones de congregaciones seculares y restauraciones de regulares. Mínimas serán las referencias, si necesarias ${ }^{6}$.

\section{Estado de la cuestión}

Que el gobierno liberal isabelino autorizara una congregación secular, «no concordada», es decir, ignorada por el art. 29 del Concordato de 1851, plantea una doble cuestion: general y particular.

\footnotetext{
5 Infra II. La cuestión jurídica.. 3. La cláusula.

6 Infra II. La cuestión jurídica.. 2. Los institutos seculares.
}

Hispanja, del Mediterráneo al Atlántico Hispania Sacra 51 (1999) 
Cuestión general, ¿qué dicen los autores sobre la interpretación, que se hizo del art. 29 del Concordato de 1851, y en relación a los institutos seculares? Es probable, que, salvo más puntual investigación, los autores no parecen haber sido muy locuaces. Tema es monográfico, empero su estudio, aún en las monografías concordatarias, descuida la distinción jurídica entre regulares y seculares; abandono bisado también por las monografías sobre el derecho de asociación en España? ${ }^{7}$ Si nuestro tema se reduce a un detalle, relegado por las monografías, imaginemos cuánto hallaremos en las obras generales. Aquí el derecho está ausente, y el estudio de la mentalidad liberal en relación a los institutos religiosos: regulares y seculares, también. En estas circunstancias, la investigación poco habrá añadido a cuanto se dijo, se redijo, y se discutí sobre el tema desde el 1851 hasta el 19048. En resolución, esta particular cuestión del art. 29 del Concordato, ni aún estado parece tener; pudiera estar vagando por uno de los llamados desiertos bibliográficos de la historia de la Iglesia en España.

Cuestión particular, ¿qué dicen los autores sobre la situación legal del Colegio de misioneros, fundado por Mons. Claret? Si las monografías concordatarias se muestran avaras con el art. 29 y sus congregaciones seculares, bien puede presumirse su escasa generosidad con un singular Colegio. Pareceres son, que han de buscarse en las particulares historias de esas congregaciones seculares. Aún Máximo fue parco de noticias sobre ellas; e ignoró, al parecer, el caso del Colegio de misioneros de Mons. Claret'.

El estado de la cuestión se adelgaza, ¿qué se dice en la Congregación claretiana sobre su existencia legal, sancionada por el gobiemo isabelino? La vida dió la primera respuesta, y en $1861^{10}$. Evidente, el diligente titular de toda institución gran cuidado pone en tener los papeles en regla. Los titulares de la Congregación claretiana también ${ }^{11}$. Y los obispos, devotos de los Misioneros ${ }^{12}$.

\footnotetext{
7 Un ejemplo, J. DE SALAZAR ABRISQUETA (ed.), Storia del Concordato di Spagna conchiuso il 16 marzo 1851 e della convenzione addizionale al medesimo Concordato, stipolata il 25 agosto 1859, di Vincenzo Nussi.., Anthologica Annua, 20(1973)823-1116, presentación, 823-831, intenta superar el calificativo económico del Concordato.

8 Vide Apéndice bibliográfico.

9 A. SALCEDO RUIZ, El anticlericalismo y las ordenes religiosas en Espanta.., Madrid 1908, 242-254, cita la petición de Ana O'Reylly, 21 enero 1857, y del obispo de Pamplona en 1867; información común, J. POSTIUS Y SALA, El código canónico aplicado a Espafia.., Madrid 1926, p. 311, n. 392; infra II. La cuestión juńdica.. 3. La cláusula..

10 Noticia de algunos documentos pertenecientes a la Congregación de Misioneros del Inmaculado Corazón de María, Vich 1861, p. 3. doc. $1^{\circ}$. Aprobación de la Congregación por el Gobiemo de S. M.

11 Certificado de existencia legal del instituto, Anales de la Congregación de los Misioneros Hijos del Inmaculado Corazón de María, 8(1901-1902)450-452; para que surtiera los efectos consiguientes se recogieron en un impreso oficial: DIRECCION GENERAL, Madrid, Buen Suceso, 18, Certi-
} 
Afirmada la vida legal de la institución por su gobernante, al historiador compete razonarla. ¿Cómo los misioneros del padre Claret han razonando su existencia legal? Tal vez, cortos de razones hayan sido. Razones, que aún pudieran equivocarse con noticias, y reducir la historia a una crónica, y general.

El 13 de enero de 1893, en el vapor inglés «Mendoza» entre Panamá y Guayaquil, el padre Xifré, «segundo» del Instituto claretiano, firmó su Crónica de la Congregación. El había vivido en primera persona las impaciencias de los años de 1858 a 1859 persiguiendo la aprobación de los Estatutos; importunó en la secretaría del obispado de Vic, en gobernación de Barcelona.. y de tanta fatiga alivió su Crónica; otros intereses tenía, que acercan su Crónica a la historia "maestra de la vida» ${ }^{3}$. Falto este testigo excepcional, el resto de las narraciones pudieran confundirse con una crónica de sucesos ${ }^{14}$; la excepción es un manual de derecho ${ }^{15}$. En la debilidad de una revista popular se aventuró una de las razones de este acto de «alta política» isabelina: la Unión Liberal aprobó los estatutos del Colegio de misioneros de Mons. Claret a causa del efecto moralizador de sus misiones: abortaban las asonadas revolucionarias en Madrid ${ }^{16}$.

En resolución, salvo más puntual información, el tema de las congregaciones seculares del art. 29 , pudiera estar todavía intonso. Las «razones» de una tal situación se afrontan querellosas. El investigador del Concordato del 1851 inculpa al investigador particular de estas congregaciones: no le sirve material. Presto el reprendido se descarga: las monografías del Concordato descuidan el

ficación del Secretario General para ser presentada, 5 de noviembre de 1924, en, Arch. Gen. Claretiano, Sec. B. ser. II, cap. 6. n. 9bis.

12 Boletín Eclesiástico de la Díocesis de Segovia, 11(1866)71-78, de oficio comunica el secretario, D. Ildefonso Infante, 4 de abril de 1866, la aprobación civil del 9 de julio de 1859, y la aprobación pontificia ad decennium del 22 de diciembre de 1865 , «es pues, por consiguiente, un instituto legal y canónico», y adjunta la Romani Pontífices del 25 de enero de 1848.

13 J. XIFRE, Crónica de la congregación de los Misioneros Hijos del Inmaculado Corazón de Maria, Anales de la Congregación.., 15(1915) 225-226, 304-305, la conclusión, 352-353, Precauciones de alta importancia; Crónica publicada sin anotación alguna; advierte inexactinudes en ella y dramatización de situaciones, C. FERNANDEZ, La Congregación de los Misioneros Hijos del Inmaculado Corazón de María. Noticia e historia general documentada.. (1849-1912), Madrid 1967, 625.

14 M. AGULLAR, Vida admirable del siervo de Dios. P. Antonio Marfa Claret.., Madrid 1894, II, 132; A. LARRAONA, Un aniversario de gloria I., Anales de la Congregación.., 15(1915) 359-362; C. Fernandez, La Congregación de los Misioneros Hijos del Inmaculado Corazón de Maria., Madrid 1967, 503-507, aprobación civil con un traslado de documentos; ibid. 246-247, la exención de quintas, noticia y traslado de dos cartas; J. ALVAREZ GOMEZ, Misioneros claretianos. 1 . Retomo a los orige. nes, Madrid 1993, 330.

15 J. POSTIUS Y SALA, El código canónico aplicado a España.., Madrid 1926, pp. 703-704, n. 679, Ordenes dotadas..

${ }^{16}$ La finción reaccionaria del clero. Las Misiones; XV, Iris de Paz, enero-febrero 1982, n. 2.607, pp. 15-17. 
planteamiento general del tema. Pues tentaré de satisfacer ambos querellantes en cuanto alcance, y animar así esta parte del desierto bibliográfico hispano.

\section{Fuentes y bibliografía}

De fuentes y bibliografía se han formado dos apéndices: documental y bibliográfico. Intentan ofrecer una información orgánica. No recogen toda la documentación archivísica, ni toda la bibliografía, usadas. Por ejemplo, se ha excusado la bibliografía de los diarios.

El Apéndice documental presenta en orden cronológico los documentos del proceso de aprobación de los Estatutos de los Misioneros claretianos; entreverado se halla el epistolario del padre Claret, testigo expectante del resultado. Muy breve la documentación de la exención de quintas. Las fuentes se han buscado en su lugar: Archivo del Ministerio de Justicia (AMJ), Archivo General Claretiano (Arch. Gen. Claretiano). La documentación recogida se puede considerar substancialmente completa ${ }^{17}$; amén de inédita la interna del Ministerio de Justicia. De uso habitual el Archivo Apostólico Vaticano (ASV); presentes también, entre otros, el Archivo de Propaganda Fide, y el Histórico Nacional.

Ingente la documentación legal impresa sobre el Concordato de 1851: aplicación y discusión en el Congreso y Senado. Los resúmenes no son de fiar; parecen emponzoñados por la mentalidad liberal ${ }^{18}$. El puntual historiador ha de papelear el Diario de Sesiones. La correspondencia del padre Claret remite a la edición más abundosa ${ }^{19}$.

El Apéndice bibliográfico agavilla una serie de entradas, vivas, sobre el Concordato del 1851. Se han recogido: autores, colecciones de documentos, estadísticas.. un muestreo de cuanto se estima necesario para el estudio particular del art. 29 en el contexto general del Concordato.

\section{Método}

El estado de la cuestión, general y particular, del tema pide guardar la proporción debida entre la investigación y divulgación; se ha intentado. Habrá advertido el lector, que no se retruecan opiniones contrarias; basta una alusión

\footnotetext{
17 Un censo de doce archivos he podido registrar en, Archivo de la Postulación General, CMF, Roma, Indice II. Indice de los Archivos.

18 A. SALCEDO RUIZ, El anticlericalismo y las órdenes religiosas en Espafia.., Madrid 1908, 247-248, referencia a los extractos del diario de Sesiones; no fue el único en declarar omisiones y tergiversaciones.

19 Epistolario Claretiano (ed. J. M. Gil), Madrid 1969-1970.
}

Hispania, del Mediterráneo al Atlántico Hispania Sacra 51 (1999) 
general. Más útil es ocupar el espacio exponiendo las propias. Espacio menguado, que fuerza una expresión literaria taquigrafica.

La mejor inteligencia de este acto de «alta política isabelina» pide una referencia a la mentalidad liberal, y, por supuesto, al art. 29 del concordato. Y ya tiene el lector razonadas las tres partes de este artículo. Precede la introducción; las conclusiones, y la añadidura de un epílogo, lo cierran

El Apéndice documental transcribe por entero las piezas integrantes del proceso de aprobación de los Estatutos, y reduce a su regesto el epistolario claretiano entreverado. Se ha modernizado la ortografía. Los archivos se identifican por su siglas propias, que en el Apéndice se desarrollan para una más sosegada lectura. No siempre se indica la foliación de los documentos, por faltar en el tiempo de su consulta.

El Apéndice bibliográfico cataloga en forma sumaria cada una de las entradas. De forma abreviada, y creemos inteligible, a él se hacen las remisiones en el interior del artículo.

\section{LA CUESTION DE MENTALIDAD: EL PUESTO DE LOS INSTITUTOS RELIGIOSOS EN LA SOCIEDAD LIBERAL}

«Mientras no se ahuyente de una vez la impiedad y el ateísmo, no sería el proyecto sino una nueva dificultad más para el Gobierno ${ }^{20}$. Parecer del Consejo Real consultado sobre: El establecimiento en la Península de casas o institutos de misioneros. Y parecer dado en 1850 , a un año escaso de la firma del Concordato, que sí establecí casas y colegios de misioneros. La mentalidad jacobina hostilizaba el cotidiano gobierno de la nación. Mentalidad, cuyo poder bien valor6 Mons. Claret, muy fatigado ya por la aprobación de su Colegio de misioneros ${ }^{21}$. El Consejo Real reconoce en el proyecto de casas de misioneros las «elevadas miras» del Gobierno, y avisa los inconvenientes de una favorable decision ${ }^{22}$.

El general ciclo de la revolución liberal (1830-1914) también se hubo en España con la particular cesura del 1868. Liberales continuaron los posteriores gobiernos de la Restauración, pero de otra manera. Aunque una parte de la opinión pública fue contraria a los institutos religiosos con el Concordato de

\footnotetext{
20 AMJ, leg. 4.121, Expediente sobre la creación de casas 6 institutos de misiones, Madrid 3 de julio 1850 .

21 Apéndice documental, n. 15, temen ser silvados por sus colegas.

22 M. TORRES CAMPOS, Bibliografia espafiola contemporanea del derecho y de la política.., Se. villa 1883, 97-98, Derecho político administrativo, Tratados particulares. k. Consejo de Estado, los títulos suelen intercambiar Consejo Real y Consejo de Estado.
} 
1851 primero, y con la ley de Asociaciones de 1887 después. Mentalidad, tropiezo advertido para el gobierno, y que no impidió legalizar el Colegio de misioneros claretianos.

\section{Los institutos religiosos ante la opinión pública de la sociedad liberal}

La opinión pública, «ese tremendo, monstruoso, animal primitivo», es común especie en la fauna de toda sociedad ${ }^{23}$. De la sociedad liberal hispana también. Opinión pública jacobina, que se cref́a única en España. «iPor ventura no hay más opinión que la de los que gritan, la de los que apedrean, la de los que procuran incendiar conventos?.. ¿No os parece opinión la de esa multitud de gentes que de tal modo acuden a sustentar las Ordenes religiosas, que producen ese florecimiento, que es el que tanto os alarma y os espanta?». Y un reto cerró la oración del Sr. Maura, Presidente del Consejo de Ministros: levantad vosotros, anticlericales, instituciones semejantes ${ }^{24}$. Sesión del 5 de noviembre de 1904.

El triste tópico de las dos Españas afrontadas se repite en la cuestión de los frailes: «o detrás de ellos con la tea, o junto a ellos con el cirio». Pugnaces se embisten razones viscerales, y otras que buscan su apoyo en la historia. Las razones vitales, pedidas por el Sr. Maura, los anticlericales nunca las dieron.

a. La opinión pública en la sociedad liberal contraria a los institutos religiosos

En la grey liberal descubrió Fernando VII «mucho simple, y también algunos bribones, y créanme vuestras mercedes, muy bribones». Y tan bribones fueron algunos de ellos, que levantaron su edificio liberal con los materiales de la sociedad precedente, con los bienes de los frailes y la frailada ${ }^{25}$.

La mentalidad de los tales «bribones» se mantiene intacta desde 1834 hasta el 1904, y después también ${ }^{26}$. Una repugnancia visceral siente una parte de la

23 J. ORTEGA Y GASSET, Mocedades (Austral, 201), Madrid 1959, 155; F. MuRILlo FERROL, Estudios de sociologia polf́tica, Madrid 1963, 91-134, la opinión pública; C. Cossio, La opinión pública.. $4^{a}$ edición corregida y aumentada, Buenos Aires 1973; J. L. DADER, El marco interdisciplinar y especifico de la investigación sobre la opinión pública.., Revista de estudios políticos, $\mathrm{n}$. 39(1984)209-227.

24 Diario de las Sesiones de Cortes. Senado. Legislatura de 1904 a 1905, Madrid 1905, I, 285, 5 de noviembre de 1904.

25 J. RICO Y AMAT, Diccionario de los poltíticos, o verdadero sentido de las voces y frases mas usuales entre los mismos.., Madrid 1855, 206, frailada, la tuatanza de los frailes; F. MUNS Y CASTELLET, Los martires del siglo XIX.. Cronologfa de las órdenes religiosas. con un prólogo por Felix Sarda y Salvany, Barcelona 1888, 13-150, indica los asesinados.

26 J. POSTIUS Y SALA, El código canónico aplicado a España.., Madrid 1926, pp. 318-325, n. 399, Antecedentes sobre la reforma del Concordato, Negociaciones de 1901 a 1908; SECRETARIADO

Hispania, del Mediterráneo al Atlántico Hispania Sacra 51 (1999) 
grey liberal hacia los frailes. ¿Por qué existen todavía los frailes y las monjas, promulgado el Estatuto?, se preguntaba incrédulo un liberal en $1835^{27}$. Maravilla, que sorprendió aún más a otro liberal en 1904. No podían ser contemporáneos: la libertad de imprenta, la ley de asociaciones, el sufragio universal, y los frailes y las monjas ${ }^{28}$. Situación insostenible, que el gobernante tenía remediar. Y el llamado a ello en España habría de ser un émulo de WaldeckRousseau y de su principio de gobierno: «el gobernante ha de ser virtuoso, honrado, inteligente, y anticlerical» ${ }^{29}$. Anticlericalismo emocional, que expulsaba frailes y monjas, y les negaba el común amparo de la ley de asociaciones, o transformaba ésta en un instrumento de opresivo control.

Aversión ideológica, que buscó la firmeza de unos racionales fundamentos en la polémica protestante e ilustrada contra los institutos religiosos con el particular añadido de la revolución liberal. Argumentos, que propuesta la cuestión de los institutos religiosos, se esgrimían con mayor o menor habilidad y virulencia.

Histórico es el común denominador de la andanada de acusaciones contra los institutos religiosos. Cada una de ellas justifica su legal disolución y el abominio de verlos de nuevo. Protestante el primer ataque: los institutos religiosos son excrecencias históricas en la Iglesia, y antievangélicos los votos profesados. Hubo un tiempo en que no existieron, por tanto, bien pueden ahora no existir. Incluso muy justa y necesaria ha sido su supresión. Y como prueba, se encadenan las razones ilustradas: el estado no puede tolerar en su seno un cuerpo político, dependiente del exterior, de la corte de Roma; en sus orígenes fueron los institutos un semillero de virtudes, pero ahora estaban relajados a causa de las enormes riquezas acumuladas en perjuicio del estado y de los particulares ${ }^{30}$; instituciones además cargadas de privilegios, inútiles para la sociedad, salvo tres institutos, dedicados al alivio de la «humanidad doliente»; institutos perjudiciales para sus mismos miembros, pues los votos solemnes contrarían la naturaleza humana. De la lucha liberal la última razón: miembros de los institutos religiosos han tomado las armas y pasado a la «facción» en

DE INSTITUTOS RELIGIOSOS DE ESPAÑA, Ley de confesiones y congregaciones religiosas. Texto, fuentes y critica en llustración del Clero. Primera edición, Madrid 1933.

27 M. DEL CAMPO, Coleccion de opúsculos sobre materias interesantes en las circunstancias del dia, Madrid 1835.

28 L. MOROTE, Los frailes en España, Madrid 1904, 45-46.

29 L. MOROTE, Los frailes en España, Madrid 1904, 5-6.

${ }^{30}$ M. MARTINEZ AlCuBilla, Diccionario de la administración española. Cuarta edición, Madrid 1886, 334, religioso con remisión a monasterios. 
contra de la libertad y de la civilización ${ }^{31}$. ¿Qué más podía alegarse, para justificar la necesaria supresión de los institutos religiosos?

Pues sí, entre los viejos y nuevos delitos: religiosos, políticos, económicos, filosóficos, históricos, «cometidos» por los institutos, uno faltó a la cita: el delito demográfico. Célibes eran sus miembros, circunstancia que empobrecía el país: substraían brazos al campo y al ejército. La estadística sorprendió a Madoz, un progresista, fervoroso admirador suyo; titubé, supuso, y balbució ante los datos ${ }^{32}$. Que el celibato fuera una causa de la despoblación de los estados es un claro error sostenido por algunos economistas, sentenció Golmayo, auditor del Supremo Tribunal de la Rota; y se atrincheró tras la autoridad de Say y de Montesquieu ${ }^{33}$.

Tanto había embebido esta mentalidad la opinión pública, el «espíritu público», que se representó en el teatro: espejo de la vida. En 1834, si una monja salía en una comedia, por fuerza ésta tenía que ser mala; juicio que suspendió a Larra, liberal. Y toda una obra teatral, Electra, prestó su nombre a un ministerio liberal en la bisagra del siglo XIX y XX ${ }^{34}$. A despecho de razones, firme se mantuvo la creencia: «los institutos religiosos no convienen al siglo en que vivimos, pues contradicen la revolución, nos vuelven a los nebulosos días de los siglos XIII y XIV». Y aún en contra de la experiencia de otros países ${ }^{35}$.

En resolución, ¿qué se puede esperar de los institutos religiosos?, desafiaba La Iberia en $1857^{36}$. Ningún bien, respondía in continenti. No hay porque pensar en su restablecimiento. El Concordato en 1851 había previsto casas y colegios de misioneros. En ese mismo año de 1857, el arzobispo Claret volvi6 de

${ }^{31}$ M. DEL CAMPO, Colección de opúsculos. Cuademo tercero. Galerfa de institulos religiosos, Madrid 1835, una peculiar historia de la vida religiosa sobre el tema de la relajacion, riquezas e inutilidad; J. del CASTILLO Y MAYONE, Los exterminadores o planes combinados por los enemigos de la libertad para dominar la especie humana bajo el pretexto de defensores del altar y del trono, Barce. lona 1835; IDEM, Frailomania o grande historia de los frailes, Barcelona 1836; IDEM, El fraile o la reliquia entre las ruinas, Barcelona 1837; P. DE URQUINAONA Y PARDO, España bajo el poder arbitrario de la congregación apostolica. Tercera edición. Por.. Benemérito de la Patria declarado por las Cortes, y en la actualidad cesante, Madrid 1835.

32 P. MADOZ, «Población de España», en COMISION DE EsTAdistica GENERAL DEL REINO, Anuario estadistico., Madrid 1860. XXV-XXXVIII, bo firma en Zarauz, 6 de agosto de 1860, casados en el censo del 1768: un 37\%, y en 1857: un 36\%; solteros en 1768: $56 \%$, y en 1857: $57 \%$.

33 P. B. GolmaYo, Instituciones del derecho canónico. Segunda edicion, Madrid 1866, I, 413$415, \$ 402$, Consideraciones generales sobre el celibato.

34 A. SALCEDo RUIZ, El anticlericalismo y las órdenes religiosas.., Madrid 1908, 329-362, el ministerio Electra y la persecución de los religiosos, 1900-1901.

${ }^{35}$ Las 6rdenes religiosas en los estados modemos, Madrid 1911, expone la situación legal fuera de España, los institutos gozan de libertad para instalarse y desarrollarse. dia 8.

${ }^{36} \mathrm{C}$. RuBIO, [Sobre el art. 29 del Concordato], La Iberia 16 diciembre de 1857, continua hasta el 
Cuba, y en Madrid, confesor de Isabel II, solicitó la aprobación de los Estatutos de su Colegio de misioneros.

b. La opinión pública en la sociedad liberal favorable a los institutos religiosos

Ser liberal o reconocer el gobierno liberal no aparejaba la tea para incendiar un convento de frailes. El padre Claret nunca se paso a la facción, y tachado de absolutista, ibérica fue su fidelidad a Isabel II. Primero como ecónomo en Sallent, después como misionero, que evitó la Berga carlista, y en Cuba como arzobispo de Santiago. Confesor real escribió su Autobiografía, una encubierta apología de la Reina y la justificación de permanecer a su lado. El padre Claret confortó a la Reina partorienta de su hijo, Alfonso XII, y tuvo la feliz invención del tal nombre ${ }^{37}$. En resolución, ser liberal, o vivir en la sociedad liberal, no equivalía a profesar la fe jacobina.

Los partidarios de los institutos religiosos en la sociedad isabelina rebatieron los argumentos contrarios, para «evitar que el espíritu público se extraviaras. $Y$ aún avanzaron las razones de su restablecimiento ${ }^{38}$. Sin faltar quien alzara la misma bandera liberal: la libertad, para acoger bajo su amparo al fraile, a su sayal y a su rincón. Negárselo era una tiranía. La libertad individual y el derecho de asociación eran suficientes para legalizar la «vuelta de los frailes» ${ }^{39}$. Y, ¿por qué no podían poseer bienes, sujetos a las leyes como quier ciudadano y sus asociaciones? ${ }^{40}$. No comprendían la razón de un trato tan discriminatorio y antiliberal; aunque para un «democrata» un instituto religioso fuera una asociación de ciudadanos, y para un católico una parte integrante de la Iglesia ${ }^{41}$.

Algunos de los partidarios de los frailes también manifestaban sus razones de forma visceral: las laudes se entonaban y seguían sin estridor alguno ${ }^{42}$. La persecución sufrida, ¿no podía interpretarse como una suerte de merecida purificacion? ${ }^{43}$. No era difícil parar los ataques contra los institutos religiosos.

${ }^{37}$ Det nacimiento y bateo de Alfonso XI, Madrid 1857, Jris de Paz, n. 2.642/4(1988)10-11; n. $2.642 / 5(1988) 16-17 ;$ n. $2.642 / 6(1988) 9-10$

$38 \mathrm{AMJ}$, leg. 4221, Contestaciones de los obispos para la ejecución del Concordato.

39 D. R. M. DEL C, Observaciones critico jurídico canonicas.., Salamanca 1858, 25-27 se proclama la libertad individual y otros derechos imprescriptibles, y se niega al hombre un burdo sayal y un rincón; P. B. GoLMAYo, Instituciones del derecho canónico.,, Madrid 1866, I, 329, \$322, Consideraciones sobre la supresión de las órdenes monásticas.

40 M. F. PERALDI, Sugli istituti ecclesiastici e loro possedimenti.., Roma 1850, 7.

41 A. SALCEDO RUIZ, El anticlericalismo y las órdenes religiosas en España.., Madrid 1908, 491.

42 J. M. ANTEQUERA, Las órdenes religiosas, Madrid 1880.

${ }^{43}$ Reforme, Analecta Juris Pontificii, 26(1886-1887)1127-1147, plan propuesto a Pío VII, en 1814, por Antonio Sala, secretario de la Congregación de la Reforma; los institutos, afirma Sala, se 
Estos pertenecían al mismo ser de la Iglesia: Cristo era su fundador, históricas sus formas ${ }^{44}$. Y, si estaban relajados, la supresión no remediaba el tal estado. Los vicarios españoles habían atajado el inconveniente de un extranjero, superior general de los frailes del Reino $0^{45}$ Que los institutos fueron contrarios a la civilización, se rechazaba con desdeño, ¿quiénes estaban en Ultramar? iquiénes moralizaban la sociedad? ${ }^{46}$ ¿Eran inútiles? Si inútil se reputaba la oración, lo serían los contemplativos, pero no los de vida activa ${ }^{47}$. Y en cuanto a las riquezas, cierto que tenían, $y$, ¿qué había hecho de ellas, arte y bienes, la revolución liberal? ${ }^{48}$. Que los institutos religiosos fueran justamente suprimidos por «facciosos», obtuvo primero un mentís en los años cuarenta ${ }^{49}$, y después en los cincuenta el calificativo de mala $\mathrm{fe}^{50}$.

habran hecho indignos de sus padres fundadores, habían abandonado el noviciado, recibido vocaciones abundantes y sin probar, descuidado el estudio, la vida común material, introducida la perpetuidad en los cargos, y concedidas muchas exenciones a los particulares; que los regulares necesitaban reforma era, por desgracia, una realidad: Conventus Episcoponum, Loreto, 24 febrero -11 marzo 1850, en Collectio Lacensis, VI, 773-810, la reforma de los regulares, 806-807, el $\mathrm{n}^{\circ} 12$, los obispos italianos estiman, que suprimir algunos conventos sería un escándalo, y ruegan a S. S. Pio IX su reforma para que sean epiù utili alle rispettive diocesi, e più edificanti pel popolo»,

${ }^{44}$ La teología, la historia, la poesía.. todos son optimos medios para expresar la pertenencia de la vida religiosa al ser eclesial; A. C. FERNANDEZ, Desaparición de los instifutos religiosos en España, Madrid 1850, 14, el estado religioso no es otra cosa que una consagración voluntaria y estable al divino servicio y propia santificación por la práctica de los preceptos y consejos evangélicos.. la hermosura de la Iglesia no sería completa si faltase este adorno, el Evangelio no se profesaría llenamente, si sus consejos estuvieran desterrados de ella; J. BALMES, Cartas a un escéptico en materia de religión, [ed. Obras completas, Barcelona 1925, X, 335-356, las cartas 23 y 24) los religiosos son esenciales a la Iglesia, pertenecen a su ser, sin ellos al catolicismo falta el calor de la vida; en el, Porvenir de las comunidades religiosas (ed. cit., IV, 305-343) las describe como un producto espontáneo en la Iglesia, su esencia es idéntica, (seguir a Cristo: pobre, casto, obediente), varía su forma.

45 Infra II. La cuestion jurídica.. 1. Supuestos jurídicos.. b. La dependencia directa. .

46 Origen de las revoluciones. Articulo religioso-social, La Cruz, 6 de abril 1842, se prolonga hasta el día 11, la Iglesia católica pone coto a las demasías del poder.. pone freno al crimen... y concluye pidiendo paz.

47 J. POSTIUS Y SALA, El código canónico aplicado a España.., Madrid 1926, p. 248, n. 369, IV, posibilidad para las monjas de clausura de abrir escuelas, la S. C. de Obispos y Regulares el 15 de abril de $\mathbf{1 8 1 6}$ comisionó al Patriarca de las Indias para que pudiera delegar a los diocesanos, y lo hizo el 5 de julio del 1816.

48 J. RICO Y AMAT, Diccionario de los polfticos o verdadero sentido de las voces y frases mas usuales entre los mismos.., Madrid 1855, 145, desamortización eclesiástica: «resurrección del tesoro publico, lázaro moderno más leproso que el de las Escrituras», y continua con un remedo: «Si buscas milagros mira/ contentos los irritados/ muchos desnudos vestidos/ y muchos hambrientos hartos/, Ruega a Madoz por nosotros/ Antonio, glorioso y santo/s.

${ }^{49}$ El clero español en los úttimos ocho años, La Cnuz, 12 de marzo 1842, se prolonga hasta el día 24, «el clero no ha profesado más milicia que la de Cristo, la que pelea contra los vicios y libra las almas del pecado... Y, zun Merino y un Echevarria? Mil veces se ha contestado a esta objeción, ni cuatro, ni cuarenta, ni cien sacerdotes representan las opiniones de todo el clero... Infortunado cuanto paciente y virtuoso clero, consuélate con el testimonio que te dá tu propia conciencia de cumplir tus

Hispania, del Mediterráneo al Atlántico Hispania Sacra 51 (1999) 
Afrontadas las dos mentalidades y enrocadas en sus razones, impotentes resultaban para resolver la cuestión legal: ¿pueden existir institutos religiosos, asociaciones, en la sociedad liberal? Y, ¿cuándo podrán volver los institutos religiosos a España? Balmes dio la respuesta, y sin posibilidad de contradicción, «Cuando haya libertad». Real suposición, y lacerante, para quienes se apellidaban paladines de la libertad contra la opresión.

2. Las posibilidades de existencia legal de los institutos religiosos en el estado liberal

Existencia legal de unas instituciones regulada por las leyes. Estado liberal es el gobierno isabelino, que la concede, aún hostigado por la «pública opinión». Los gobiernos liberales han de gobernar una sociedad, cuya base sociológica es católica. Imposible eludir el dilema: ordenar los asuntos de la Iglesia de acuerdo con la Santa Sede, o ignorarla ${ }^{51}$. El concordato posibilita un arreglo, y la persecución ocupa su ausencia. Curiosa situación en una sociedad, defensora de la libertad.

Por tanto, la existencia legal de los institutos religiosos en la sociedad liberal depende de los artículos de un concordato, materia del derecho eclesiástico del estado. Político es lo convenido entre ambas altas partes contratantes. Y en el gobierno de los pueblos la política es el arte de lo posible.

a. Posición liberal jacobina: negación del Concordato, y del derecho eclesiástico del estado

Firmar el concordato con la Santa Sede para el arreglo de los asuntos eclesiásticos resulta intolerable a la mentalidad jacobina: es una humillación del estado, merma de su autoridad. Primero, la Iglesia pertenece al pasado, una reliquia de la superstición, de la opresión; después, el estado liberal no reconoce superior a ninguna autoridad. Se considera igual a los demás estados; domi-

evangelicos deberes"; FCo J. TORRES, Repertorio de parrocos, Madrid 1850-1857, 7 vols, I, 11, dedica su obra a Arrazola, la Introducción es todo un programa, 6-7, la Iglesia protege la libertad, no esa libertad anárquica, sombría.. sino la libertad que ternpla y reforma las pasiones de los príncipes, que prescribe sus deberes, que aboga por la causa de los oprimidos, y apura, en fin, todos los recursos de una caridad admirable; vide también la censura, Madrid 22 de jumio de 1849, exculpa a la Iglesia de la «necia imputacion de favorecer el despotismo».

So D. R. M. DEL C, Observaciones crftico juridico canonicas.., Salamanca 1858, 25-27.

51 La vita religiosa nella storia della Chiesa e della società, Milano 1997, 774-818; P. B. GOLMAYO, Instituciones del derecho canonico.., Madrid 1866, I, 21-23, Relaciones entre la Iglesia y el estado: \$17. de resistencia, \$18. de tolerancia, \$19. de libertad, \$20. de protección; J. GIRON Y ARCAS, La situación juridica de la Iglesia catótica en los diversos estados de Europa y America. Notos para su estudio, Madrid 1905. 
na como autoridad única y absoluta sobre su territorio nacional; su voluntad es la ley positiva sin las falacias de la ley divina o natural. Todas las instituciones de la sociedad liberal, que no sean estatales, son privadas, y sujetas a la pública ley del estado. Se excusa humillarse ante una potencia extranjera para ordenar los propios asuntos internos.

¿A qué viene el Sr. Brunelli? Preguntaba irritado el marqués de Albaida en $1847^{52}$. Y en torno a la misma firma del Concordato se enzarz6 una constante polémica hasta el no-nato del $1904^{53}$. Y después también ${ }^{54}$.

La mentalidad jacobina rechaza el concordato. $Y$ vencedora suprime institutos, simples cofradías, y repite la frailada ${ }^{55}$. Estos son los impíos y ateos, que en opinión del Consejo Real en 1850, estorbaban aún el proponer la posibilidad del establecimiento de casas y colegios de misiones. «¿Cuáles son los errores liberales?», se respondía: «propugnar la abolición de los institutos religiosos, especialmente de hombres, considerándolos inútiles, y hasta perniciosos» ${ }^{56}$.

b. Posición liberal conciliatoria: aceptación del Concordato y del derecho eclesiástico del estado

Vistos los resultados de los excesos jacobinos, el mismo sentido común pidió un arreglo de los asuntos eclesiásticos de acuerdo con la Iglesia. El concordato napoleónico, en 1801, abrió la serie de ellos entre la Iglesia y el estado liberal $^{57}$. Y surgí el derecho eclesiástico del estado, y la regulación de los institutos religiosos.

Admitida la posibilidad y la conveniencia del concordato, la grey liberal matiza forma y contenido. Variedades, que en la sociedad isabelina pudieran reducirse a tres posiciones: progresistas, moderados, y neo-católicos.

52 J. M. ORENSE y MiLA DE ARAGon, El Concordato. Por el autor del Folleto, ¿A qué viene el Sr. Bnunelli?, Madrid 1847.

53 El Consultor de los parrocos, en el mes de agosto de 1872, naturaleza del concordato, el Concordato francés del 1801; J. PostiUS Y SALA, El código canónico aplicado a España.., Madrid 1926, pp. 318-325, n. 399, Antecedentes sobre la reforma del Concordato, Negociaciones de 1901 a 1908.

54 M. CARAZON Y DE LA ROSA, - M. GRANADOS AGUIRRE, - A. SEgovia, Legislación española. Leyes religiosas según los textos oficiales. , Madrid 1935; el cambio, L. PEREZ MIER, La Iglesia y estado nuevo. Los concordatos ante el modemo derecho público, Madrid 1940.

55 C. FERNANDEZ, La Congregación de los Misioneros Hijos del Inmaculado Corazón de Maria. Noticia e historia general documentada. (1849-1912), Madrid 1967, 665-688, en La Selva (Tarragona) murio mártir el misionero Francisco Crusats, 30 septiembre 1868.

56 Breves apuntes y materias predicables para uso de los Misioneros Hijos del Inmaculado Corazón de María Parte tercera [El Espíritu de la Congregación], Barcelona 1885, 30-35, Conferencia IV. Sobre el liberalismo, el espiritismo y el masonismo.

57 La vita religiosa nella storia della Chiesa e della società, Milano 1997, 781-783; la novedad de los concordatos liberales, P. B. GolmaYo, Instituciones del derecho canónico.., Madrid 1866, 1 , $99-100, \$ 112$. Concordatos.

Hispaniá, del Mediterráneo al Atlántico

Hispania Sacra 51 (1999) 
Los progresistas aceptan el concordato, pero, sin dejar el vellón del estado prendido en las zarzas romanas; exasperación de la soberanía del estado liberal, heredera del jurisdiccionalismo ilustrado. Defienden aplicar el pase regio a las encíclicas papales. El concordato es una exigencia política, y «no ha de ceder a la opinión pública hasta el punto de llegar a la ruptura con la Santa Sede» ${ }^{58}$. La fe progresista se mantiene equidistante del absolutismo y del socialismo, y rechaza la acusación de impíos y ateos. Veneran la religión en su moralidads9.

El progresista arreglo de los asuntos eclesiásticos no alcanza a los frailes. Al contrario, son combatidos en nombre de la religión, del estado, y de la economía. Basta el clero secular para cumplir los fines religiosos ${ }^{60}$.

Los moderados, en 1851, firmaron el Concordato con la Santa Sede ${ }^{61}$. Buscaron para mejor gobernar la «concordia entre el sacerdocio y el imperio». El Concordato se levantó sobre los trabajos de una Junta Mixta. Ambas partes cedieron, y dejaron que el tiempo desarrollara sus artículos, y en forma confidencial sin exasperar la opinión pública. Los moderados no renuncian al jurisdiccionalismo, aunque conceden el carácter de públicos a los boletines diocesanos ${ }^{62}$.

La Iglesia ha de alcanzar «sus grandes y civilizadores destinos» sostienen los moderados $^{63}$; y gran parte en ellos tienen los institutos religiosos. Materia de su derecho eclesiástico son casas y colegios de misioneros, sujetos a ciertas condiciones.

58 Las Novedades, 22 de agosto de 1855, estamos en el Bienio, y «Preciso es por consiguiente, adoptar y seguir una conducta que de paso satisfaga las más justas de las exigencias de la opinion, y evitar en cuanto sea posible un conflicto entre la iglesia y el estado, un rompimiento formal entre el gobierno de S. M. y la Santa Sede»; M. F. NUÑEZ MUÑOZ, - F. DIAZ DE CERIO, El Bienio progresista (1854 - 1856) y la ruptura de relaciones de Roma con Espafta según los documentos vaticanos, La Laguna 1993.

59 Las Novedades, 21 de julio 1857, en la revista de prensa La lberia contesta a El Parlamento: el partido progresista no es ateo, y considera tan barbaro y absurdo el absolutismo como el socialismo.

60 C. RUB1O, [Sobre los frailes] Sección doctrinal, La Iberia, sábado 23 enero 1858, los liberales combaten a los frailes por interés de la religión, como los combatieron Erasmo y san Buenaventura, y por razones políticas, no pueden tolerar en el estado un cuerpo extranjero, y por razón económica; defiende el pase regio de la bula de la Inmaculada; P. B. GoLMAYo, Instituciones del derecho canonico.., Madrid 1866, I, 41-42, \$52 Leyes vigentes sobre la materia [Pase o regium exequatur]

61 ASV, Arch. Nunz. Madrid, 311, tit. VI. busta 3, Madrid, 3 mayo 1848, Sotomayor-Amao, el «gobiemo moderado puede considerarse como una restauración.. el gobiemo hizo mucho, abrió el camino de las paces, el tribunal de la Rota, suspendio la venta de bienes.. realizo la reconciliación con la iglesia.., hoy en 1848 la Europa esta despierta, hay que acomodar la marcha a las exigencias de la época y al giro de las opiniones».

62 La circular del Ministerio de Gracia y Justicia, Madrid, 12 julio 1862, firmada por S. Fernández Negrete, AMJ, Eclesiásticos, leg. 4038, n. 21542

63 Madrid, 8 de enero de 1852 , para la ejecución del Concordato, texto L. CUCALON Y EsCOLANO, Exposición del Concordato de 1851, Madrid 1853. 217-218, 
Y en tercer lugar los neocatólicos. Neos, pues mantienen en la sociedad liberal una posición de los tiempos de la Cristiandad: la superioridad del poder espiritual sobre el temporal. Se les achaca de «serviles» ante la autoridad papal. El concordato sería para ellos la sumisión a lo querido por la Corte de Roma ${ }^{64}$.

La mentalidad neocatólica propugna el establecimiento de los frailes. No parecen inquietarlos las reservas de los moderados frente a los regulares, la dependencia directa de Roma. Su opinión pública ensalzó y pidió la vuelta de los regulares.

La vida práctica, el estado de la Iglesia en España, pedía una solución. Y el gobierno isabelino moderado establecio casas y colegios de misioneros para España y Ultramar.

\section{Los institutos religiosos èn la preparación del Concordato de 1851}

Por real decreto del 8 de marzo de 1836 y ley de Cortes del 29 de julio de 1837 fueron suprimidas las órdenes religiosas en la Península e Islas adyacentes; excepción hecha de los misioneros para Ultramar, escolapios, hospitalarios, hermanas de la Caridad y beatas, rebajadas a instituciones civiles de beneficencia.

Los trabajos concordatarios comenzaron en 1845 y concluyeron en 1851; excúsase aún su desnudo elenco ${ }^{65}$. Baste advertir que la Comisión Mixta creyó oportuno establecer casas y colegios de misioneros ${ }^{66}$. El 8 de mayo del 1849 las Cortes autorizaron al gobierno ajustar el Concordato. La base $3^{a} \mathrm{del}$ art. $1^{\circ}$ de la ley de autorización incluía casas e institutos de misiones ${ }^{67}$. El 29 de sep-

64 Supongo que hubieran firmado gustosos con García Moreno el Concordato: Ecuador-Santa Sede, del 26 septiembre de 1862, y su art. 20 sobre los religiosos, y suplicado al Papa los medios de reforma de regulares, en, F. HERNAEZ, Colección de bulas.. América y Filipinas.., Bruselas 1879, II, 637-638.

55 F. SuAREZ, Génesis del Concordato de 1851, lus canonicum, 3(1963)65-249, incluye el texto en latfn y castellano, reducido a la documentación del Ministerio de Asuntos Exteriores; J. PEREZ ALHAMA, La Iglesia y el Estado espafiol. Estudio historico-juridico a través del Concordato de 1851, Madrid 1967, con documentación de archivos pontificios, y publicación del Proyecto y de la Memoria justificativa; la ya citada obra de Vincenzo NUSsI, Storia del Concordato di Spagna conchiuso il I6 marzo 1851; J. POSTIUS Y SALA, El codigo canonico aplicado a España.., Madrid 1926, Pp. 264-284, nin. 380-383, incluye textos.

66 J. Perhz Alhama, La Iglesia y el Estado español., Madrid 1967, 480-481, el proyecto, 576578, la menoria justificativa; la memoria secreta de los Srs. Seijas Lozano, y González Romero, infra; otro tema de vida religiosa: La Junta Mixta de 1848 y la desamortización de los bienes de las Ordenes Militares, Hidalguía, 34(1986)49-80, 235-270.

67 A. M. CLARET, «Concordato celebrado en el año de 1851», en Miscelánea interesante.., Barcelona $1865,202, \ll 4^{\circ}$. Establecer convenientemente la ensef́anza e instrucción del clero, y la organi-

Hispania, del Mediterráneo al Atlántico Hispania Sacra 51 (1999) 
tiembre de 1849, de Real orden, el Ministerio de Gracia y Justicia, pidió su parecer al Consejo Real ${ }^{68}$.

Ya en la Junta Mixta los pareceres sobre los regulares no fueron muy firmes. A su informe del 27 noviembre 1848, los Sts. Seijas Lozano, y González Romero adjuntaron una memoria secreta el 20 diciembre de $1848^{69}$. También en el Consejo Real hubo división de opiniones: la mayoría entregó su informe, y uno contrario la minoría, en la que formaba Donoso Cortés; y cuya refutación la mayoría creyó necesaria.

a. El establecimientos de los religiosos, cuestión particular en el arreglo general del clero

El establecimiento de los frailes: ¿es necesario? ¿posible? ¿cómo? Medida legal en choque con las luces y dineros, y dentro del general arreglo de los asuntos eclesiásticos. La Junta Mixta primero, y el Consejo Real después, reconocieron la necesidad de la Iglesia para la reconstrucción moral del país por medio de misiones, de predicaciones. La forma de congregación, de colegios, era la más conveniente. La Santa Sede exigía el restablecimiento de los institutos religiosos ${ }^{70}$.

Primera cuestion, ¿basta el clero secular para moralizar el país, combatir la relajación de los vínculos sociales, resolver las necesidades misioneras de UItramar, formar los sacerdotes? La respuesta era un no sin paliativos. Que los cabildos o las comunidades de beneficiados pudieran substituir a los antiguos regulares era un sueño, como lo eran las casas de venerables, convertidas en colegios de misioneros ${ }^{71}$. Los congregados en Cuba sí ayudaron al arzobispo de Santiago, Mons. Claret ${ }^{72}$.

zación de seminarios, casas e institutos de misiones, de ejercicios y corrección de eclesiásticos, y dotar de un clero ilustrado y de condiciones especiales a las posesiones de Ultramar y demás establecimientos que sostiene la Nación fuera de Españan.

$68 \mathrm{AMJ}$, leg, 4121, Expediente sobre la creación de casa 6 institutos de misiones, Madrid 29 de septiembre 1849: «se ha dignado mandar S. M. que el Consejo Real proponga lo que estime conveniente sobre el establecimiento en la Península de casas e institutos de misiones como de ejercicios y corrección de eclesiásticos, y sobre la organización que se deba darles»; el comento a la 3 base por los obispos, en ASV, Arch Nunz Madrid, 320

${ }^{69}$ L. Euo GaraY, Apéndices al escrito.. s/a s/d, n. I. C) Memoria secreta de los Srs. Seijas Lozano, y González Romero.

70 La nota reservada del 1 de enero de 1847, ASV, Arch Nunz, Madrid, 305, 3; J. PostIUS Y SALA, El código canónico aplicado a España.., Madrid 1926, pp. 710-713, n. 685.

71 Las comunidades de beneficiados en Cataluña impugnadoras de los principios desamortizadores y sucesoras de las extinguidas brdenes religiosas en el s. XIX, Hispania Sacra, 44(1992)161-200.

72 L. FRIAS, Historia de la Compañia de Jesús. Tomo segundo volumen primero (I835-1868), Madrid 1944, 229; el padre Claret se encontro en Cuba con estos Congregados, Epistolario Claretiano, n. 171, pp. $488-494$, comunicación al Capitán General de Cuba, s/d.

Hispania, del Mediterráneo al Atlántico Hispania Sacra 51 (1999) 
Segunda cuestión, ¿era posible el establecimiento de los institutos? El Consejo Real dudaba, impíos y ateos lo estorbaban, sería un tropiezo para el gobierno. «Las pasiones se han encandescido extraordinariamente», advertían los Sres. Seijas Lozano, y González Romero.

Tercera cuestión ¿cómo se podrían establecer los necesarios institutos sin alborotar la opinión pública? Y, si restablecidos, ¿quiénes y en qué condiciones? Arduas cuestiones todas ellas, pues había que seleccionar los institutos, y proveer después a su mantenimiento y acomodo, y sin tocar los bienes desamortizados.

El Consejo Real en su parecer de ochenta largos infolios se debatió entre la necesidad de los institutos y las dificultades, que entorpecían su establecimiento. Se declaró un difícil particular capítulo del arreglo general del clero. Resolverlo era cuestión de «alta política». líticas"

b. El establecimiento legal de los institutos religiosos, cuestión de «alta po-

«Los oficios y grandes cargos no son otra cosa sino un golfo profundo de confusiones», advertía Don Quijote, caballero andante, a Sancho, gobernador ${ }^{73}$. Junta Mixta y Consejo Real reconocían la necesidad de los institutos. Empero, su restablecimiento era cuestión de «alta política», de profundas confusiones. Excesivas pasiones y dineros enturbiaban las inteligencias.

Un gobierno liberal, defensor de la libertad, ¿«podía prohibir que unos hombres.. se reúnan y vivan en común inofensivamente bajo las reglas de un instituto religioso, sometiéndose a todas las medidas que la autoridad puede inventar para asegurarse de sus fines, de su conducta y hasta de sus intenciones»? Los Srs. Seijas Lozano, y González Romero juzgaron de tiranía inaudita el prohibirlo ${ }^{74}$. Lógica conclusión liberal: concédase libertad de asociación a los institutos suprimidos. No era posible, una razón económica lo vetaba. Restablecidos cundiría la alarma entre los compradores de sus bienes. La economía de los particulares y del estado, bienes no vendidos, imponía su inaudita tíranía a los institutos religiosos. Y también lo impedía una segunda razón, fortísima, la mentalidad adversa. «Todo, hasta los actos más inocentes se convierten en arma de partido, y una medida de esta naturaleza indudablemente se pintaría como hija de un plan encaminado a sofocar la libertad y enderezado a una reacción espantosa».

${ }^{73}$ Don Quijote, parte II, cap. 42.

${ }^{74}$ L. EUJO GARAY, Apéndices al escrito.. s/a s/d, p. 8, C) Memoria secreta de los Srs. Seijas Lozano, y González Romero, «Si la cuestión se examina en la region de los principios.. [negar a los religiosos el derecho de asociación].. sería el colmo de la tiranía, y sólo el pensarlo subleva la conciencia del hombre».

Hispania, del Mediterráneo al Atlántico Hispania Sacra 51 (1999) 
¿Cómo salir airosos del lance? Pues de la única forma posible: con medias palabras para no alborotar la opinión pública, y con la promesa del futuro desarrollo del Concordato «tan pronto las circunstancias lo permitan» ${ }^{75}$. También se admite el primer paso de una congregación secular. La Corporación de eclesiásticos establecida en el monasterio de El Escorial, «no es más que un pretexto»; el fin era un instituto religioso ${ }^{76}$.

Muy susceptible era la opinión pública. La noticia de que el Consejo Real entendía en el establecimiento de los institutos alborotó los perí́dicos progresistas en 1850: venía la amenaza de los frailes. El Heraldo calmó los ánimos: no se hablaba de frailes, sino de casas e institutos misioneros. Y señalaba dónde estaban las verdaderas amenazas ${ }^{77}$.

\section{LA CUESTION JURIDICA: LOS INSTITUTOS RELIGIOSOS EN EL ARTICULO 29 DEL CONCORDATO DE 1851}

Balmes en los años cuarenta declaraba falsa la proposicion: «he visto pasear un fraile por la rambla de Barcelona». No era posible. Después del 1851 fue posible ver frailes en España, en camino de Ultramar, y casas y colegios de misioneros en ayuda de párrocos y obispos ${ }^{78}$. Existen los institutos religiosos, pero de otra manera ${ }^{79}$. Medida concordataria, pedida por la necesidad, y templada por la prudencia para no alarmar la opinión pública exagerada.

En el Concordato del 1851, las «altas partes contratantes» convinieron sobre los religiosos en el art. 29, y sus paralelos. Redacción clara una parte y

75 J. Perez Alhama, La Iglesia y el Estado español., Madrid 1967, 353, las negociaciones sobre los art. 29 y 30 fueron calificadas por Mons. Brunelli: «dei più imbarazzanti, e molesti».

76 Epistolario claretiano, n. 733, Claret-Don Dionisio, La Granja, 7 agosto 1859 ; n.736, ClaretCurríus, Segovia, 16 agosto 1859 , «pues se va a poner un noviciado para que se viva la vida primitiva con toda perfección, esa es la voluntad de S. M. aunque se le da nombre de Corporación de eclesiásticos, esto no es más que un pretexto». Se pretendía restablecer los jerónimos; A. M. CLARET, «Monasterio del Escorial», en Miscelanea interesante.., Barcelona 1865, 101-179.

77 El Heraldo, 9 de marzo 1850, Parte política, «son los intereses materiales los que preocupan los ánimos, la amenaza está en la avidez de gozar, la falta de creencias y el olvido de las leyes etemas del orden moral»; el 10 de marzo dice tratarse de una affagaza para alarmar a los liberales, y a quien ha comprado los bienes nacionales.

78 La Regeneración, 17 de agosto de 1860, una coplilla: No vestirse de frailes: Orden de Ultramar, 24 septiembre 1866, en Revista Catolica, 32 (1866) 314.

79 J. AGUIRRE, Curso de disciplina eclesidstica general y particular de España. Segunda edición, Madrid 1858, II, 340-365, ordenes religiosas, III, 503-504, fundación de monasterios. 
deliberadamente confusa la otra. Lo mismo sucedió en Italia con su Concordato y su también artículo $29 \mathrm{~b}^{80}$.

Claro o confuso que fuera el art. 29 ofreció base legal al Colegio de misioneros de Mons. Claret; la aprobación de sus Estatutos lo suponen; la exención de quintas lo declaran ${ }^{81}$. Texto del artículo inteligible en su mentalidad y entorno jurídico-económico; después en fiel correspondencia con su letra la práctica fue clara y confusa, $y$, por ende, discutida.

\section{Los supuestos jurídico-económicos subyacentes en el artículo 29}

Herencia del jurisdiccionalismo ilustrado son los supuestos jurídicos: distinción entre los institutos religiosos y su jurisdicción. El económico tiene la añadidura liberal de la desamortización.

a. La distinción entre los institutos religiosos: regulares y seculares

Distinción elemental para entender la vida religiosa, su historia y su protección jurídica. Se abrevian tiempos y razones. Tres son los esquemas de vida religiosa y sus correspondientes distinciones: el esquema, que estriba sobre el Corpus Iuris Canonici, legislación tridentina, y posterior, hasta el código del 1917 ${ }^{82}$; el esquema del código del $1917^{83}$, y el esquema del código del $1983^{84}$. No está permitido barajar indistintamente los códigos y sus esquemas, los tiempos, y el lenguaje.

Distinción entre regulares y seculares, que no escapó a Alcubilla, ni a Salcedo Ruiz ${ }^{85}$. Y, no obstante, una publicación oficial parece retener propio de

80 J. SOTO de Gangort, La Santa Sede y la Iglesia Católica en Espafia, Madrid 1942, 34, texto; V. DEL GiUdICE, Codice delle leggi ecclesiastiche, Milano 1952, 203, 1055.

81 Infra. III. La cuestión de gobiemo..

82 Estamos antes del código del 1917, por tanto, religioso tiene dos significados: en sentido estricto es el regular, de votos solemnes, y en sentido amplio, es el secular de votos simples o sin ninguin género de votos, pero que vive more regularium; vide, La vita religiosa nella storia della Chiesa $e$ della Società, Milano 1997, 822-892; El ordenamiento de los institutos de votos simples según las Normae de la Santa Sede (1854-1958) (Sudia Urbaniana, 42), Roma-Madrid 1993.

${ }^{83}$ La vita religiosa nella storia della Chiesa e della Società, Milano 1997, 893-937; Sobre la evolución jurfdica de los «nuevos institutos» de votos simples (1830-1947), Archivio Comboniano, 32/2(1995)263-318; Los institutos seculares en el ordenamiento de los knuevos institutos de votos simples (1830-1947). Apostilla al n. 10 de la exhortacion Vita consecrata, Commentarium pro religiosis, 78(1997)241-295.

84 Las variaciones del tetulo y del sistema: De religiosis, durante la reformatio Codicis, 19661983, Claretianum, 36-37(1996-1997)285-424.

85 M. MARTINEZ AlCUBILlA, Diccionario de la administración española. Cuarta edición, Madrid 1886, 334, religioso, votos solemnes, regla, aprobación papa; A. SALCEDO RUZ, El anticlericalismo y las 6rdenes religiosas en España.., Madrid 1908, 10-11, ordenes, religiosos, comunidades de

Hispania, del Mediterráneo al Atlántico Hispania Sacra 51 (1999) 
Alemania lo que era común de la Iglesia entera ${ }^{86}$. Distinción de capital importancia también en el estudio de la vida religiosa femenina ${ }^{87}$. Providencia elemental, entonces, y ahora cuando se recupera su vida: no barajar institutos religiosos: seculares o regulares, y ambos con las comunes cofradías.

Los regulares emiten votos solemnes, exentos están de la jurisdicción episcopal, y sus institutos lo son supradiocesanos e internacionales ${ }^{88}$. Añádase, que el subconsciente liberal les atribuyó riquezas sin cuento en el pasado, y en el futuro una capacidad ilimitada para adquirirlas; nuevos Cresos capaces de convertir en oro cuanto tocaban ${ }^{89}$. Y, amén de inútiles, salvo en las misiones de Ultramar y beneficencia, resultaban muy perjudiciales para la sociedad. Circunstancias todas que alteran el sosiego liberal, aún el de los moderados.

Los seculares constituían el reverso de la medalla. No emitían votos, o si los emitían eran votos simples, no perdían su personalidad jurídica. Quedaban bajo la jurisdicción episcopal, y por tanto diocesanos, no eran exentos. Resultaban muy útiles a la sociedad por dedicarse a obras de beneficencia, a moralizar al pueblo, y a sostener los trabajos de obispos y párrocos ${ }^{90}$.

En resolución, el gobierno liberal no restablecerá un instituto regular, sino es para confinarlo en Ultramar al servicio útil de la Iglesia y del Estado. En cambio, los institutos seculares gozarán de todos sus favores, pues era evidente su útil servicio a la Iglesia y al Estado. Distinción entre los institutos religiosos, que constituye la base fundamental del texto del art. 29.

Visto lo que precede, se retiene «indispensable y urgente reorganizar sin demora la congregación de san Vicente de Paúl» ${ }^{91}$. y, después, la congregación

votos simples, que en España solemos llamar congregaciones, se remite a Morales Alonso, Buitrago, García Ocaña; en honor de la verdad en sus dos volumenes de Instituciones de derecho canonico, Madrid 1895, Morales y Alonso no parece decir una sola palabra de los frailes.

86 CONGRESO DE LOS DIPUTADOS, Apuntes para el estudio del proyecto de ley.., Madrid 1906, II, en el Apéndice, XIII-XIV, referencia a la situación alemana, se distinguen: órdenes, congregaciones, y cofradras, el papa autoriza votos simples y solemnes, los obispos las cofradias [y también las congregaciones de votos simples], órdenes y congregaciones se establecen de acuerdo con el jefe de estado.

${ }^{87}$ La condición juridica de beatas y beaterios. Introducción y textos. 1140-1917, Anthologica Annua, 43(1996)287-586.

88 Obvio, que se entiende en los masculinos.

89 Y no sin razón; basta imaginar las riquezas que puede acumular una sociedad productiva cuyos miembros, no tienen vacaciones, no hacen huelga, el trabajo es considerado un acto de virtud, y su forma de vida es muy morigerada y simple, y sin pagar transmisión de bienes por herencia; con la administración de un buen padre de familias el crecimiento económico está asegurado. La cuestión se plantea en cómo gastar el dinero.

90 BergIER-MONescillo, Diccionario de Teologia.., Madrid 1847, I, 448-449, Comunidad eclesiástica; 482, Congregación; 485, Congregaciones seculares.

91 Real decreto, San Idefonso, 23 de julio de 1852, Historia contemporánea del clero español correspondiente a I85I y I852, Madrid 1853, 135-136. 
de clérigos seculares de san Felipe Neri ${ }^{92}$. Varias Reales cédulas «mejoran los colegios de Misiones para Ultramar», pues, «han prestado importantes servicios.. en la propagación de la Santa Fe Católica, reduciendo y convirtiendo a ella a las tribus.. y también en la sumisión de las mismas a mi Real corona..n93.

b. La dependencia directa de los institutos religiosos de autoridades españolas

Exigencia del gobierno liberal moderado, que es herencia jurisdiccionalista. Los regulares estaban exentos de la jurisdicción episcopal del reino. Y como no se toleraba extranjeros en el gobierno de los institutos hispanos, los jurisdiccionalistas habían arrancado de la Santa Sede los vicarios españoles para su gobierno ${ }^{94}$. Siendo los institutos seculares diocesanos, pues dependían de los obispos, no era necesaria tal providencia, salvo el caso del privilegio ${ }^{95}$.

Que los institutos establecidos dependieran de los diocesanos, era la última línea del art. 29 en el Proyecto de Concordato de 44 artículos, que el marqués de Pidal entregó a Brunelli el 2 de agosto de $1850^{96}$. La Santa Sede no aceptó la «coletilla»; conculcaba el universal derecho canónico. Empero se comprometió, firmado el Concordato, a publicar un breve, y satisfacer las exigencias de los liberales moderados. El nuncio, Brunelli, dio su palabra y la cumpli6 $6^{97}$. Pío IX emanó el breve Regularium personarum, 12 abril 185198, fue ejecutado mediante Real orden el 22 de octubre de $1851^{99}$. Y Miraflores reclamó su pronta

92 Real decreto, Palacio, 3 diciembre de 1852, Historia contemporánea del clero español correspondiente a 1851 y 1852, Madrid 1853, 169-170.

93 Reales cédulas, Palacio 19 octubre 1852, Historia contemporánea del clero español correspondiente a 1851 y 1852 , Madrid 1853, 171-177.

94 J. PostiUS Y SALA, El código canónico aplicado a España.., Madrid 1926, pp. 247-248, n. 369; el asunto de la dotación, pp. 700-701, n. 675; PIO VII, breve, Inter graviores, 15 mayo 1804; GREGORIO XVI, breve, In suprema, 3 marzo 1832.

95 L. Euo GaRAY, Apéndices al escrito.. s/a s/d, p. 8, C) Mernoria secreta de los Srs. Seijas Lozano, y Gonzalez Romero.

96 . PEREZ ALHAMA, La Iglesia y el Estado espafiol.., Madrid 1967, 312, texto, 322.

97 AMJ, Aclaraciones al Concordato, leg. 4.121, 16 de marzo de 1851.

98 J. PostiUS y SALA, El código canónico aplicado a España.., Madrid 1926, p. 285, п. 386. Motuproprio Regularium, se prevéa un decenio; pp. 698-700, nn. 671-674, Jurisdicción, el decreto Peculiaribus inspectis, 10 diciembre 1858, sujetó exclaustrados y monjas a los diocesanos, situación que se renovaba de trienio en trienio; y asf continuó para las monjas, el 26 de octubre de 1927 el nuncio en España, Mons. Tedeschini ejecutó el indulto de S. C. DE RELIGrosos, del 12 julio 1927, X. OCHOA, Leges Ecclesiae, n. 786; y un indulto ejecutó de nuevo el nuncio, Mons. Cicognani el 16 mayo del 1940, OCHOA, n. 538; siempre en relación al Peculiaribus inspectis.

99 Publicado en, La Gaceta, del 23 de octubre de 1851; Colección legislativa de España, 44(1851), n. 957, pp. 365.66

Hispania, del Mediterráneo al Atlántico

Hispania Sacra 51 (1999) 
aplicación el 29 de noviembre del $1851^{100}$. Durante el Bienio progresista (18541856) no se toleraron distingos; todos los religiosos bajo los diocesanos ${ }^{101}$.

Y el escrúpulo jurisdiccionalista y liberal se quitó. La Congregación secular de san Vicente de Paúl se restablece. El art. 2. del Real decreto reorganiza su gobierno «Sin perjuicio de que conforme al breve apostólico, estén sujetas al ordinario.. el visitador general.. deberá tener en la corte su residencia... ${ }^{102}$. Y la Congregación secular de san Felipe Neri, «con arreglo al breve apostólico de 12 de abril de 1851, [Regularium personarum] quedará sujeta a los ordinarios» ${ }^{103}$. Y la tercera cédula para el incremento de los Regulares, misioneros en Ultramar, en la más pura tradición jurisdiccionalista pide para su gobierno un vicario, natural de estos reinos; vicario del general del instituto con sede en Roma ${ }^{104}$.

c. La base económica de los institutos establecidos por el artículo 29

El restablecimiento de los institutos religiosos había alarmado a los compradores de bienes de regulares. Y al estado, que los restablecía, también. ¿Dónde se iban a levantar los seminarios de misiones y las casas-misión? ¿Cómo sustentar sus miembros?

A todo proveyó y satisfizo el Concordato. Los institutos fueron restablecidos a tenor del art. 29; artículos paralelos aquietaron la conciencia de los compradores de «bienes nacionales», y sosegaron al estado, propietario de los no vendidos ${ }^{105}$.

«El Santo Padre, a instancia de S. M. Católica y para proveer a la tranquilidad pública», decreta, que los comprađores de bienes eclesiásticos no serán molestados, art. 42. El Estado reconoce a la Iglesia su derecho de adquirir, art. 41. Estado, compradores e Iglesia disfrutan de su pacífico derecho de propiedad. Alojar y mantener a los institutos restablecidos era un capítulo del arreglo general del clero ${ }^{106}$. En conformidad con el art. 35 del Concordato, el Gobierno de S. M. se compromete a proveer por los medios más conducentes a la sub-

\footnotetext{
${ }^{100}$ ASV, Arch. Nunz, Madrid, 336, Cotnunicaciones de diversos polf́icos, Miraflores-Brunelli. 1855.

501 ASV, Arch. Nunz. Madrid, 336, Esecuzione del Concordato, ordini religiosi, 15 de marzo

102 Real decreto, San Ildefonso, 23 de julio de 1852, Historia contemporánea del clero español correspondiente a 1851 y 1852 , Madrid 1853, 135 .

103 Real decreto, Palacio, 3 diciembre de 1852, Historia contemporánea del clero español correspondiente a 1851 y 1852 , Madrid 1853,170, art. 11.

104 Reales cédulas, Palacio 19 octubre 1852, Historia contemporánea del clero español correspondiente a 1851 y 1852 , Madrid 1853, 173-175.

105 J. Postrus y SALA, El código canónico aplicado a España.., Madrid 1926, pp. 904-907, n. 911, la propiedad y la desamortización eclesiástica.

106 AMJ, Aclaraciones al Concordato, leg. 4.121, Aranjuez, 11 de junio 1852, el marqués de Miraflores.
} 
sistencia de las casas y congregaciones del art. 29. Y «atendidas las circunstancias» el producto de la venta de los bienes, que subsistan, se invierte en deuda del Estado al 3 por ciento ${ }^{107}$.

La ejecución del Concordato tradujo en cada caso los «medios más conducentes» de alojamiento y subsistencia de los institutos establecidos y de sus miembros. Dar incremento a los regulares en misiones y establecerlos no significaba entregarles sus antiguas temporalidades. Las cédulas todo lo previenen, cargan sobre el Estado: «proveer en cuanto fuera necesario a su decorosa subsistencias ${ }^{108}$. Los Reales decretos, que establecen las congregaciones seculares, se resumen en providencias económicas: número de miembros de cada casa y calidad: no menos de 6 sacerdotes y 3 coadjutores, sin superar el número de 18 de la primera clase y 8 de la segunda. La renta anual de cada individuo de la congregación de san Vicente de Paúl no podía exceder de 2.500 reales ${ }^{109}$. Los miembros de las congregaciones, casas, de san Felipe Neri han de tener la congrua exigida por las constituciones ${ }^{10}$ Un buen empleo ministerial era de 6.000 reales; y 6.000 duros el «lecho de espinas» de un ministro ${ }^{111}$. En dos o tres reales diarios se resumía la pensión de un exclaustrado, si la cobraba, igual que un bracero. Y en cuanto a los edificios vieja era la providencia del $1849^{112}$.

El Estado había de sustentar los necesarios institutos religiosos; sin descuidar la ayuda de los particulares, «excitados por el bien que reciben de ellos». La estadística con sus tablas de bienes y de personas venía en socorro del Estado. Ahora es Negrete, de la Unión liberal, quien se muestra muy satisfecho de los estadísticos servicios ${ }^{113}$.

${ }^{107}$ Art. 35, 38.

108 Reales cédulas, Palacio, 19 octubre 1852, Historia contemporánea del clero espantol correspondiente a 1851 y 1852 , Madrid 1853, 173-174.

${ }^{109}$ San Ildefonso, 23 de julio đe 1852, Historia contemporánea del clero español correspondiente a 1851 y 1852 , Madrid 1853, 135-136.

110 Real decreto, Palacio, 3 diciembre de 1852, Historia contemporánea del clero español correspondiente a 1851 y 1852, Madrid 1853,169, art. 5

III J. RICO Y AMAT, Diccionario de los politicos o verdadero sentido de las voces y frases mas usuales.., Madrid 1855, 237,

132 AMJ, Eclesiásticos, leg. 3.760, n. 12.720, Expedientes referentes a la circular del 12 de diciembre 1849, y 28 febrero 1850 , sobre edificios de conventos suprimidos que pueden destinarse a casas e institutos de misioneros, ejercicios y corrección de eclesiásticos; la Real orden del 28 de febrero, en Colección Legislativa de España, 49(1850)464-465, n. 190.

113 S. FERNANDEZ NEGRETE, [10 febrero 1860, suplica el Real decreto de estadística], en MINISTERIO DE GRACIA Y JUSTICIA, Guía del estado eclesiástico de España para el año de 1860 , Madrid 1860, 855-861.

Hispania, del Mediterráneo al Atlántico Hispania Sacra 51 (1999) 


\section{Los institutos seculares establecidos por el artículo 29}

Nos reducimos a los institutos seculares. Límite necesario: el Colegio de misioneros de Mons. Claret es secular. Se abstrae de los Colegios de misioneros regulares para las misiones de Ultramar: jesuitas, dominicos, franciscos, agustinos: calzados y recoletos... hospitalarios ${ }^{114}$. Excúsase aún aludir a los intentos de restauración de otros regulares ${ }^{115}$. Las circunstancias del 1900 entablaron la discusión en torno a las órdenes concordadas y no concordadas ${ }^{116}$. Otras son las circunstancias del período isabelino. Lo de órdenes úsase en un sentido vulgar.

El art. 29 señala los fines que piden y legitiman el restablecimiento de los institutos seculares; fines servidos por las dos órdenes concordadas. Todo en armonía con la mentalidad liberal moderada: congregaciones seculares, útiles, diocesanas o un vicario, que vive en la corte; se establecen «oyendo previamente a los prelados diocesanos», y en un «número suficiente», expresión que ataja un crecimiento desmesurado.

a. La justificación de los institutos seculares concordados: auxiliares de prelados y de parrocos

El texto del art. 29 quiere un «número suficiente de ministros y operarios evangélicos, de quien puedan valerse los Prelados para hacer misiones en los pueblos.. auxiliar a los párrocos, asistir a los enfermos, y para otras obras de caridad y utilidad pública». Todos estos fines se alcanzaban en la Península e Islas Adyacentes mediante dos instituciones: la casa-misión y el Seminarium clericorum $^{117}$.

El Consejo de Estado en su informe sobre la Ley de bases había discutido la institución de la casa-misión, que lo era habitación de misioneros y con el añadido de servir de casa de corrección de eclesiásticos y de reposo de ancianos ${ }^{118}$, Fines que el Consejo de Estado en 1850 consideró incompatibles entre sí. La letra del Concordato obvió la dificultad con una expresión literaria: las define como «lugares de retiro para los eclesiásticos, para hacer ejercicios espirituales y para

114 MENISTERIO DE GRACIA Y JUSTICIA, Restumen de la Estadística General Eclesiástica.., Madrid 1860,44 , cuadro comparativo, agustinos, calzados y recoletos, dominicos, franciscos, una casa cada uno con destino misiones de Filipinas; jesuitas 3 casas con misiones a Cuba; escolapios 29 casas, enseñanza; los textos de la autorización real en, Concordato celebrado en el año de 1851.., Boletín Eclesiástico de la diócesis de Segovia, 1859-1860, 142-154.

115 ASV, Arch. Nunz. Madrid, 444, desde el 1862 al 1868; infra nota 153.

116 A. LOPEZ PELAEZ, El derecho y la Iglesia... Tercera edicion, aumentada, Madrid 1911, 479480, La ley del candado, del 27 diciembre de 1910.

${ }^{117}$ Supra, I. Cuestión de mentalidad: 3. Los instizutos religiosos.. a. El establecimiento..

118 Los hermanos coadjutores en las Constituciones del P. Claret y una consueta de la casamisión de Vich, Claretianum, 24(1984)79-196. 
otros usos piadosos». La vida demostró, que una casa-misión con tales fines era inviable. Amarga experiencia del padre Xifré, «segundo» del padre Claret, con la fundación de la casa-misión de Gracia. Que no se repitió en Astorga ${ }^{119}$.

El Seminarium clericorum era la versión formativa de la casa-mision; suplía de alguna manera la ausencia del seminario conciliar ${ }^{120}$. En él ofrecían los misioneros, congregados, a los candidatos al sacerdocio un ambiente apropiado para el estudio, la oración, y formación sacerdotal.

El episcopado entero pedía misiones en 1850, misioneros, y casas-misión ${ }^{121}$. Y los seglares también ${ }^{122}$. Y el padre Claret; en su Episcoporum stimulus, obra escrita durante su viaje de retorno de Cuba en 1857, ponáa un colegio de misioneros en cada dícesis ${ }^{123}$. Eclesiásticos, que se honraban con el título pontificio de misionero apostólico ad honorem ${ }^{124}$. Congregaciones, colegios de misioneros, favorecidos también por la traducción de unas reglas italianas ${ }^{125}$.

La opinión pública progresista vivía en continua alarma ante las misiones: enemigas de la libertad y de la civilización. El padre Claret, misionero en Cataluña (1840-1849), encubría la realidad de una misión bajo el título de novena. Y nunca logro dar una misión en Reus, prototipo de ciudad liberal. En la confusión habida después de la revolución de 1868, pueblos de toda España, presentaban sus dudas al ayuntamiento de Reus, y pedían la solución. ¿Se debía tomar la bula? El ayuntamiento de Reus respondi6, «que ellos no se preocupaban de esas cosas, y aquí nadie la toma».

\section{b. Los institutos seculares concordados: Paúles y Filipenses}

Los Misioneros seculares del Salvador del Mundo, y los Píos Operarios de Francisco Ferrer habían sido las dos congregaciones seculares hispanas autóc-

119 ASV. Arch. Nunz Madrid, 442, Xifre-Barili, 11 de agosto 1866, no se fundó a pesar de no existir en la djócesis un «centro de moralidad»; Epistolario Claretiano, n. 1248.

120 Apunte sobre el seminario eclesiástico precedente de los institutos clericales de misioneros, Claretianum, 26(1986)315-339.

121 ASV. Arch. Nunz, Madrid, 352.

122 R. TAVares y Lozano, Manifestación hecha a las Cortes sobre la necesidad y conveniencia de las misiones en España, Madrid 16 mayo 1857, AMJ. Eclesiásticos, religiosos, leg. 3.760, con registro de entrada el 13 de junio de 1857.

I23 A. CLARET, Episcoporum stimulus, Madrid 1865, nn. 12, 13, p. 51; colegios de misioneros para Cuba los pidió en 1851, Epistolario Claretiano, n. 180, Exposición a S. M. la Reina.

124 Quaedam de Missionarii Apostolici titulo aad honorem noviter concesso, Commentarium pro religiosis, 63(1981)372-386; 64(1982)170-185.

125 ASV, Arch Nunz Madrid, 305, Carte di niuna importanza, con las Regole e costituzioni della congregazione de' Missionary di Maria Ssma del Buon Consiglio, Roma 1847, 23, traducidas se presentaron al Nuncio entre 1851-54. Se pide establecer casas o colegios misioneros, formados con arreglo al adjunto cuademo.. a lo menos en las capitales del Reino; obtuvo la agregación a Propaganda el 12 julio 1847 .

Hispania, del Mediterráneo al Atlántico

Hispania Sacra 51 (1999) 
tonas; se les añadieron dos más foráneas ${ }^{126}$. En 1851 el gobierno liberal encontró sólo las dos foráneas: los clérigos de san Vicente de Paúl, los Paúles, y los clérigos de san Felipe Neri, los Filipenses; olvidó los Misioneros del Salvador, madrileños, y aprobados también por la Santa Sede ${ }^{127}$. Es muy probable, que en 1845, comienzo de los trabajos del Concordato, los Misioneros madrileños ya se hubieran extinguido ${ }^{128}$.

Paúles y Filipenses poseían todos los requisitos exigidos a un instituto religioso por los liberales moderados: seculares, aprobados por la Santa Sede, sus iglesias y casas-misión «desde siempre» habían servido «de lugares de retiro para los eclesiásticos, para hacer ejercicios espirituales y para otros usos piadosos». Cucalón y Escolano los defendió, y aún invocó para ellos el común derecho de asociación ${ }^{129}$. El 23 de julio de 1852 fueron restablecidos los Paúles ${ }^{130}$, los Filipenses el 3 de diciembre del mismo año de $1852^{131}$.

En 1859 , siete años más tarde, imperceptible se registraba su crecimiento. Tres casas tenían los clérigos del Oratorio de san Felipe Neri, y dos casas los clérigos de la Misión de San Vicente de Paúl ${ }^{132}$. ¿Por qué? ${ }^{133}$. Razón tuvo, el obispo de Pamplona, Severo, cuando advirtió, que «aunque muy útiles» Paúles y Filipenses eran poco conocidos en España; el prefería las órdenes anti-

126 AHN, Hacienda, Jeg. 4.825, n. 4.005, Madrid 8 octubre 1824, se habla de la reclusión de párocos liberales en casas de reforma como las de San Felipe Neri, Padres del Salvador, y de la Visitación o Misión, con referencia a una circular del 4 de enero 1824; F. MUNS Y CASTELLET, Las mártires del siglo XIX.. Cronología de las ordenes religiosas. con un prólogo por Felix Sardá y Salvany, Barcelona 1888, 94, un recuerdo para los Píos Operarios de Francisco Ferrer.

127 La madrileña Congregación de Misioneros Seculares del Salvador det Mundo y sus primeras constituciones, Hispania Sacra, 35(1983)529-584.

128 Una postrer noticia, Arzobispado de Matrid, Archivo Histórico, Salvador del Mundo, Fábrica y Cofradís, 4 , el 5 de abril 1835, el presidente y decano de la Congregación, extiende un informe favorable sobre uno de sus miembros, $D$. Julián de Villanueva.

129 L. CUCALON Y ESCOLANO, Exposicion del Concordato de 1851., Madrid 1853.261-262.

130 ASV, Arch. Nunz Madrid, 336, XXII, 3, Osservazioni del Superiore Generale della Congregazione di San Vincenzo di Paoli sul ristabilimento della medessima in Ispagna; y también en Arch. Nunz. Madrid, 442; J. HerRera, Historia de la Congregación de la Misión, Madrid 1949, 412-428, restauración en España.

${ }^{131}$ ASV, Arch. Nunz, Madrid, 336, XXII, 11, Congregazioni dei Padri dellOratorio di S. Filippo Neri; A. ALBA, Las congregaciones del Oratorio de San Felipe Neri en España durante el siglo XIX, Oratorium, 7(1976)89-108.

${ }^{132}$ MINISTERIO DE GRACIA Y JUSTICIA, Resumen de la Estadística General Eclesiástica.., Madrid 1860,44 , ambos en: beneficencia.

133 España es geografia de frailes, no de congregaciones seculares, amén de que el restablecimiento de las «ordenes suprimidas" encontraba muy serios problemas intemos, La vita religiosa nella storia della Chiesa e della Società, Milano 1997, 848-858; la opinión del padre Claret, Epistolario Claretiano, n. 1009, Madrid, 5 enero 1863, Claret-Xifre, la P. D. «.. el espiritu de independencia, insubordinación y rebelión se infiltra por todon, los Escolapios pedían treinta afóos de hábito antes de la profesion solemne, «los Filipenses no cuajan»... 
guas ${ }^{134}$. Muy cierto era. Empero, ¿dónde el gobierno liberal iba a encontrar en 1848 otras congregaciones seculares en España? No las había. Y en 1859 número tan exiguo de casas-misión no podía satisfacer la grandísima necesidad, que de misiones tenía el país. Situación, que contradecía la letra del Concordato, «que en toda la Península haya el numero suficiente de ministros y operarios evangélicos». Y gentes había, que echaban en cara al gobierno su ineptitud: no establecía las necesarias congregaciones de misioneros ${ }^{135}$. Y, ¿el gobiemo podía hacerlo? Sí, contestó Fernández Negrete en 1861: «El gobiemo pudiera crear una nueva orden que está concordada, y, sin embargo, no la ha creado. No hay más religiosos que los de san Felipe Neri, y san Francisco de Paúl (sic), que están encargados de las Hermanas de la Caridad. Hay algunas otras casas, pero son misiones para las provincias de Ultramar, grande, grandísimamente provechosas para la Patria» ${ }^{136}$.

Visto que el gobierno no creaba la «orden concordada», las crearon los particulares, y solicitaron su aprobación. ¿Era ésta posible a tenor del Concordato y de su art. 29?

\section{La cláusula de la tercera orden concordada en el artículo 29}

El art. 29 establece dos congregaciones seculares: Paúles, y Filipenses. Y una expresión sibilina desliza la posibilidad de establecer una tercera orden: «..otra Orden de las aprobadas por la Santa Sede». El gobierno es quien la establece y mantiene.

En su memoria secreta, los Srs. Seijas Lozano, y González Romero, miembros de la Junta Mixta, sugirieron borrar del esquema del Concordato la mención expresa de las «dos órdenes» ${ }^{137}$. No fueron escuchados. ¿Por qué? Ignoro las razones, que avalaron el rechazo de la enmienda, empero se pueden suponer. Si el gobiemo liberal no hubiera identificado las dos Congregaciones seculares, el texto del art. 29 hubiera legalizado la «vuelta de los frailes», execrada por «impíos y ateístas». Y bien advirtió el Consejo de Estado las posibles consecuencias de una tal decisión.

Pues, «medida de alta política» fue identificar dos congregaciones seculares, y dejar abierto un portillo para el establecimiento de toda suerte de insti-

134 ASV, Arch Nunz Madrid, 333, 25 febrero 1852, responde a una circular de Gracia y Justicia sobre el restablecimiento de regulares, del 7 de diciembre de 1851.

135 J. SENDON LAMELA, Recuerdos al gobierno sobre el Concordato, La Regeneración, 6 diciembre 1861 .

136 CONGRESO DE LOS DiPUTADOS, Apuntes para el estudio del proyecto de ley.., Madrid 1906, I, 635-637, Legislatura 1861-1862, Senado contestación al discurso de la Corona.

${ }^{137}$ L. EJo GaRAY, Apéndices al escrito.. s/a s/d, p. 17.

Hispania, del Mediterráneo al Atlántico

Hispania Sacra 51 (1999) 
tutos: regulares y seculares, cuando las «circunstancias lo aconsejaran» ${ }^{138}$. Intención evidente, que los arts. 43 y 45 del Concordato sostienen.

a. Las interpretaciones encontradas sobre la cláusula de la tercera orden

Varias dificultades entorpecían establecer la «tercera orden». Su naturaleza: ¿orden regular o secular? Su número: ¿una para todas las diócesis, o diversa en cada una de ellas a elección del diocesano? ¿Puede el Gobierno establecer una orden aprobada ś́lo por el diocesano? ¿Qué hacer si faltan operarios evangéli$\cos$, si las 6rdenes concordadas no son capaces de alcanzar los fines previstos por el Concordato en su art. 29?

A los dos años de publicado el Concordato, en 1854, aún antes de comenzar el Bienio progresista, la cuestión de la tercera orden ya estaba aparcada en vía muerta. No se veía solución. Las opuestas mentalidades en torno a un texto sibilino impedían establecer la tercera orden concordada. Imposible tomar una decisión legal. A principios del siglo XX, cincuenta años eran pasados, y los nuevos combatientes se mantenían firmes y afrontados en sus posiciones ${ }^{139}$.

Los progresistas abominaban toda suerte de institutos religiosos ${ }^{140}$. José Manuel de Vadillo, en la segunda edición de su Concordato analizado, excusa detenerse sobre el art. 29: «bastante ya se ha escrito de esta materia». La mentalidad progresista no distingue entre seculares y regulares. Todos son igualmente perjudiciales ${ }^{141}$. Y el art. 29 significa la «vuelta de los frailes». Encaramados en el Gobierno revolucionario provisional del 1868 volvieron a la situación del 1837: suprimieron todo instituto o congregación fundados desde entonces; medida de salvación pública, dijeron ${ }^{142}$.

138 J. M. GARCfa OCANA, Del Concordato, Razon y Fe, 10(1904)514-522, en p. 522 la declaración de Brunelli, se usó por prudencia la tal cláusula: «para no provocar el furor de los exaltados y del periódico de su sectan; L. Euo GaraY, Apéndices al escrito. s/a s/d, p. 17, se tenían de nuevo todas las órdenes poco a poco; J. POSTIUS Y SALA, El código canónico aplicado a España.., Madrid 1926, pp. $710-713$, n. 684, IV-V.

139 A. SALCEDO RUZ, A., El anticlericalismo y las órdenes religiosas en Espafia.., Madrid 1908, 230-254.

140 En Las Novedades, 24 diciembre 1857, Patricio de la Escosura, desde el Perú, cierra en una carta contra: «El concordato espanfol resucitando entre nosotros los frailes.. reaparece en el s. XIX aquel espiritu político-teocrático que dio lugar a las interminables luchas entre el sacerdocio y el imperio».

141 J. M. de VADLLO, Concordato de 1851 analizado.., Cádiz 1854, 41, «Nada digo acerca de la ampliación que por el artículo 29 pretende darse a lo que está determinado actualmente respecto a órdenes de regulares de hombres y mugeres. Bastante se ha escrito ya en la materia, y no dudo que contra el progreso de las luces y el convencimiento público se estrellará cualquier proyecto reaccionaro de esta especie. Mal pienso sirva a la causa de la Santa Religion católica quien aspira a sostenerla con carcomidos puntales, que por robustos que se supongan baber sido en su origen, el tiempo llegó a dañarlos y desconceptuarlosn.

I42 La Cruz, 1868-II, 347-349. 
Los moderados no abominaban in solidum de los frailes, empero sus diferencias tampoco resolvían la cuestión. Unos aferrados a la letra identificaban la tercera orden con una y única para todas las diócesis, y escogida de acuerdo con los obispos ${ }^{143}$. Otros en el espíritu del Concordato incluían en la tercera orden todo tipo de institutos: regulares y seculares, y a elección del diocesano ${ }^{144}$. Y era suficiente la aprobación del diocesano, y quedar bajo su autoridad.

Si la interpretación del Concordato no se averiguaba sobre la «tercera orden», la práctica del Gobierno tampoco resolvía la cuestión de forma decisiva.

El 25 de junio de 1853, Ignacio, obispo de Oviedo, y el ayuntamiento de Villaviciosa, solicitaron el restablecimiento del colegio de Misioneros apostólicos de la localidad. Petición negada por la Cámara eclesiástica del Ministerio de Justicia el 20 de mayo de $1854^{145}$. Razón: todavía no se ha resuelto cuál ha de ser esa tercera orden. En el mismo año de 1854, Severo, obispo de Pamplona, pide restablecer el Colegio de misioneros de Olite, sobre la base de una casa de venerables ${ }^{146}$. Como todavía no se había decidido la tercera orden, nada se pudo decidir. En junio de 1857, Mariano, obispo de Cartagena, manifestó al Nuncio la precaria situación del país falto de misioneros, y acusaba al gobierno, que nada hacía por remediarla ${ }^{147}$.

En diciembre del 1857, saltó a los perí́dicos la noticia de que el Consejo de Estado entendía en la cuestión de la «tercera orden». Y de nuevo la opuesta $89-90$.

${ }^{143}$ P. de la SOTA Y LASTRA, Indicacion de las principales. Concordato de 1851, Madrid 1858,

144 L. CuCalon y ESCOLANo, Exposición del Concordato de I851.., Madrid 1853., 262-263; J. D. COSTA Y BORRAS, Exhortación pastoral, 26 de agosto 1852, Barcelona 1852, 12, el reciente Concordato basta para el restablecimiento de los institutos regulares con el favor de Dios..

145 AMJ, Eclesiásticos, Religiosos, leg. 3.760, n. 12.678, «Mientas no se resuelva que orden religiosa de las aprobadas por Su Santidad se ha de restablecer en Espana, no es posible se autorice ni consienta la erección de casas de regulares, cualquiera que sea el destino que se las dé, y por más piadoso y útil que parezca su establecimiento. Por esta razón no es posible acceder a lo que solicitan... Esa petición no puede ser atendida ni estimada por ahora, pero convendrá que se tenga presente para resolver lo que parezca oportuno cuando se trate del restablecimiento de aquella tercera orden de que se ha hecho mención»; V. GUITARTE IzQUIERDO, Episcopologio Español (1700-1867). Españoles obispos en España, Aménica, Filipinas y otros paises, Anthologica Annua, 39(1992)433-688, n. 900, p. 625, Juan Ignacio Moreno Maisanove; la Cámara eclesiástica, A. M. CLARET, «Concordato celebrado en el año de 1851», en Miscelánea interesante.., Barcelona 1865, 252-259, Real decreto estableciendo el Consejo de la Cámara eclesística, Madrid, 2 de mayo 1851.

146 AMJ, Eclesiásticos, Religiosos, leg. 3.760, n. 12.679, para contrarrestar el protestantismo y su hijo natural que es el socialismo; J. GONII GAZTAMBIDE, Historia de los obispos de Pamplona. IX. Siglo XIX, Pamplona 1991, 671-677, el obispo Severo Leonardo Andriani Escofet, recomienda el 25 de febrero de 1852 el Colegio de misioneros de Olite; V. GurTARTE IzQUIERDO, Episcopologio Espa. Fol (1700-1867).., Anthologica Annua, 39(1992)433-688, n. 797, p. 603., Severo Leonardo Andriani Escofet.

${ }^{147}$ ASV, Arch. Nunz. Madrid, 352, Murcia, 17 junio 1857.

Hispania, del Mediterráneo al Atlántico

Hispania Sacra 51 (1999) 
interpretación dividió los miembros del Consejo. Unos sostenían ser una y única la tercera orden, mientras otros incluían dentro de ella toda suerte de institutos, solicitado por el diocesano. Que este último parecer pudiera prevalecer, soliviantó la «prensa liberal», pues suponía el establecimiento de todos los institutos, resultado contrario al mismo Concordato, afirmaban. Arisco el tercio que hizo la Revista Católica: «.. hará muy bien el Gobierno (este ú otro) en ocuparse y dar a esta cuestión la solución más católicamente liberal posible; que siempre será aquella que con mayor suma de libertades restituya a la Iglesia, y con la Iglesia a los verdaderos fieles. $Y$ no se nos venga con escrúpulos infantiles. A buen pagador no le duelen prendas» ${ }^{148}$. Y como el Gobierno seguía sin ocuparse de la cuestión, en 1859, la Revista Católica insistió vapuleando la inactividad del gobierno ${ }^{149}$. En estas circunstancias, legislación dudosa, y con la grey liberal alborotada, ¿qué podía hacer un Gobierno liberal? Muy poco. Quien pretendiera la aprobación de un instituto debía seguir la vía personal, encomendarse a la Reina, y después a O'Donnell, o a Narváez.

Vía personal que el nuncio Barili sugirió en 1866. El Marqués de Ovando, como patrono, y el obispo de Coria, Esteban, como diocesano, quisieron establecer la congregación de la Preciosísima Sangre en la Diócesis. Ambos, Patrono y Diocesano, ignorantes del cómo pidieron consejo al Nuncio de $\mathrm{Su}$ Santidad ${ }^{150}$. Antes de indicar el cómo, Barili, razona la imposibilidad de una aprobación. En la cuestión de la tercera orden prevalecía el parecer del Consejo de Estado: una sola orden para todas las diócesis, y convenida por los diocesanos. Interpretación del gobierno, que no es la de la Santa Sede, subraya el Nuncio. Dificultad legal, que no se resuelve, in senso ne positivo ne negativo. Amén de que la congregación de la Preciosísima Sangre se reduce a poco más de los Estados Pontificios, observa Barili. Obstruida la vía legal, el Nuncio indica la vía personal: hablar con el Duque de Valencia, con Narváez.

El 6 de junio de 1867 la cuestión de la «tercera orden» se llevó al Congreso de diputados. La causa fue, que el obispo de Pamplona, Pedro Cirilo, solicito la admisión de novicios franciscos en Olite ${ }^{151}$. Era la segunda vez, que el dicho

\footnotetext{
148 Sobre restablecimiento de Ordenes regulares, Revista Catolica, 24(1858)94.

149 E. M. VILARASA, Resena historica. Espafta, Revista Catolica, 25(1859)267-268.

150 ASV, Arch. Nunz Madrid, 442, Ovando-Barili, 14 diciembre 1866, y la respuesta de Barili el 22 de diciembre; V. GUITARTE IZQUIERDO, Episcopologio Esparlol (1700-1867).., Anthologica Annua, 39(1992)433-688, n. 950, p. 636, Esteban José Pérez Fernández.

151 Sesión celebrada por el Congreso de Diputados en el dia 6 de junio de 1867. Ordenes religiosas, La Cruz, 1867-II, 5-55; J. M. CUENCA TORIBIO, El pontificado pamplonés de D. Pedro Cirito Uriz y Labayru (I862-1870). Contribución a su estudio, Hispania Sacra, 22(1969)129-285, el texto en pp. 283-285, Pamplona, 31 de octubre de 1866, breve comento en p. 128; J. GoNI GAZTAMBIDE, Historia de los obispos de Pamplona. X. Siglo XIX, Pamplona 1991, 186-187, vida religiosa, una
} 
Colegio solicitaba la aprobación. El Sr. Claros, diputado por Navarra, no presentó proposición de ley «porque no quiero de ningún modo suscitar aquí diferencias, y menos en la cuestión religiosay. Y de nuevo se bisó la diversa interpretación de la tercera orden. i»Nada había hecho el gobierno en 16 años»? Sí, algo había hecho el gobierno. Bastaba consultar la Guía del Ministerio de Justicia correspondiente al año de 1868. Junto a las ordenes concordadas, el gobieno había establecido una no concordada: la Congregación de sacerdotes de san Alfonso María de Ligorio, los Redentoristas; se razona su aprobación: congregación secular destinada a Ultramar ${ }^{152}$. La misma Guía ignora el Colegio de Misioneros de Mons. Claret, también establecido.

Las circunstancias pedían resolver la cuestión de la «tercera orden». El 25 de junio de 1868, Roncali, ministro de Gracia y Justicia, envió a los obispos una circular confidencial sobre puntos precisos para la ejecución del Concordato ${ }^{153}$. A principios de julio, el obispo de Vic, Antonio Luis, y el de Granada, Bienvenido, piden el auxilio de las congregaciones y ordenes religiosas, «hoy más que nunca necesarias, de que habla el art. 29 del Concordato».

noticia sobre la llamada casa de Venerables; J. POSTIUS Y SALA, El código canónico aplicado a España.., Madrid 1926, p. 311, n. 392, П.

152 MINISTERIO DE GRACIA Y JUSTICIA, Guía del estado eclesiástico de España para el año de 1868, Madrid 1868, 681, en Huete, por Real orden del 12 noviembre de 1867, «Son misioneros seculares, no regulares, pero que viven en común y sujetos a estatutos ordenados por su Santo Fundador. El objeto de la fundación es la predicación y las misiones en Ultramar y principalmente el instruir a la población rurals; ASV, Arch. Nunz. Madrid, 442, tit. 8 Madrid, 18 abril 1864 el Nuncio recomienda los Redentoristas al obispo de Cuenca, contestación, de Miguel, obispo de Cuenca el 22 de abril de 1864; V. GuTtarTe IZquIERDO, Episcopologio Español (1700-1867).., Anthologica Annua, 39(1992)433-688, n. 914, p. 628, Miguel Payá Rico; D. DE FELIPE, Fundación de los Redentoristas en España. Una aventura en dos tiempos, Madrid 1965, 65; de nuevo, F. FERRERO, Las primeras misiones populares de los redentoristas en Espafia (1863-1868), Spicilegium Historicum Congregationis Ssmi Redemptoris, 33(1985)357-451, en p. 415, la Sección de Ultramar del Consejo de Estado informa favorablemente, el ministro de Ultramar, vice-patrono concede la autorizacion de abrir la casa de misioneros en Huete, y el Ministro de Justicia comunica al obispo de Cuenca la autorización; el texto tomado đe El Pensamiento Español, que a su vez lo tomó del Boletín diocesano; M. GoMEz RIos, Primera crónica de los redentoristas en España (1863-1868), Specilegium Historicum Congregationis Ssmi Redemptoris, 40(1992)81-127, 339-407, en pp. 348-349, el Real despacho de la Reina, 2 diciembre 1867, el texto no invoca el Concordato sino «las condiciones aprobadas por la Santidad del Sumo Pontífice Benedicto XIV en veinticinco de Febrero de mil setecientos cuarenta y nueven; no he sabido encontrar el dicho texto, he revuelto Hernáez, el Diccionario de legislación de Ayala, el Bulario de Benedicto XIV; al parecer ignora Benedicto XIV, F. SAIZ DIFZ, Los Colegios de Propaganda Fide en Hispanoamérica, Hispania Sacra, 25(1968)257-318, vide fuentes y bibliografia, 258-263; ibidem, 26 (1969) 5-113.

153 AMJ, leg. 4.122, n. 2.489; J. POSTTUS Y SALA, El código canónico aplicado a España.., Madrid 1926, p. 311, n.392, I, Proyecto de Concordato sobre órdenes regulares en 1867; PARALELo en, AA. EE. SS.. Spagna. Pos. 573, Fasc. 159. Am. 1867-1868, Restablecimiento de Las Órdenes Religiosas en la Península en conformidad con el art. 29.

Hispania, del Mediterráneo al Atlántico

Hispania Sacra 51 (1999) 
b. La vivacidad de las casas-misión, de las congregaciones seculares isabelinas

La vida intentó superar la impotencia legal del gobierno. Las congregaciones seculares, casas-misiones, seminarios de clérigos surgían en España ${ }^{154}$. Comenzaron antes del Concordato y fueron troncadas por la Revolución del 1868. Comunes son sus características: sacerdotes congregados bajo la autoridad diocesana, sin gravar sobre el presupuesto, ni de la diócesis, ni del estado, dedicadas a moralizar la sociedad, y en el mayor respeto al Sumo Pontífice, nuestros Reyes y nuestras autoridades ${ }^{155}$. Propósitos expresados por D. Fernando Sánchez y Rivera, en Cuenca y en el mes de enero de 1868. Se arrojaba una nueva semilla de institutos religiosos.

El 24 de diciembre de 1849, Antonio, arzobispo de Tarragona pidió el convento de agustinos de La Selva para casa-misión y de ejercicios. Lógica la negativa ${ }^{156}$. De ello se trataba en el Concordato. En 1853 ya tenemos un colegio de misioneros en Priego bajo la jurisdicción del señor obispo ${ }^{157}$. Su noticia llegó a la diócesis de León; y al Colegio de misioneros claretianos de Segovia también ${ }^{158}$. En 1858, y en Valencia, D. Manuel Fabra y Vila funda una comunidad de clérigos seculares. Dió noticia de ella La Regeneración, 5 de enero de 1860. Al parecer el dicho $\mathrm{D}$. Manuel solicitó la aprobación del gobierno «con arreglo al art. 29». Impaciente por su tardanza, en octubre del 1864, importunó al Nuncio ${ }^{159}$. En enero del 1863, Don Manuel Abella propuso a Propaganda, en Roma, la fundación de un Colegio de Misioneros bajo la advocación de San Francisco Javier; con el permiso del Cardenal Prefecto de Propaganda solicitó en Madrid su aprobación. El expediente pasó al Ultramar, y como el Fundador no parecía muy entusiasmado con su obra, y muchas eran las dificultades, se abandon $6^{160}$. Los misioneros claretianos de Segovia el 27 de abril de 1865, comunicaron a su Director General en Vic, que: «en Granada se forma otra

154 Basta el papeleo de las relationes ad limina; en el AMI, he papeleado al menos diez expedientes sobre casas de misión; incluso el desierto carmelitano de Las Palmas (Castellón) se presentó como una casa-misión.

155 ASV, Arch. Nunz. Madrid, 444, 42.10, Cuenca 22 de enero de 1868.

155 AMJ, Eclesiásticos, Religiosos, leg. 3.760, n. 12.675, la solicita el 24 de diciembre de 1849, la negativa del 26 de septiembre de 1851 .

157 AMJ, Eclesiásticos, Religiosos, leg. 3.759.

158 Arch. Gen. Claretiano, B. A. cap. 4. n. 6., Serrat-Xifré, Segovia, 24 mayo 1863, se han presentado hermanos ayudantes de 16 a 18 afios, y no pudiendo entrar por no estar libres de quintas, uno se nos fue a Priego; los misioneros de Priego: Sociedad de Misioneros de la Inmaculada Concepción, Boletín del clero del Obispado de León, 14(1866)8, firma el Superior, Ambrosio Rozas.

159 ASV, Arch. Nunz Madrid, 448, tit. 9, n. 4, recuerda la casa de Priego.

160 Archivo de Propaganda Fide, SocG, vol 4. Spagna, fol. 26; ASV, Arch. Nunz. Madrid, 448, Manuel Abella, Madrid 12 mayo 1863. 
asociación de sacerdotes con el mismo título de nuestra congregación, cuyas bases aprobo el dicho Sr. Arzobispo» ${ }^{161}$.

En 1866, muy satisfecha la Revista Católica comunica a sus lectores el progreso de las misiones en España. Y siguiendo el ejemplo de los Misioneros del Arzobispo de Trajanópolis, Mons. Claret, «existen ya, y se van constituyendo además determinadas agrupaciones de sacerdotes en muchas diócesis para llenar el vacío de la predicación, abierto con la supresión de las comunidades religiosas» 162 .

El 30 de mayo del 1867, un antiguo soldado de la Reina, Francisco Tiburcio Arribas, misionero apostólico, eleva una representación a las Cortes para establecer una casa de misiones en cada capital de provincia ${ }^{163}$. Intención de la Congregación secular de misioneros de Mons. Claret, cuyos Estatutos había aprobado el gobierno en 1859. Misioneros, exentos de quintas el 18 de enero de ese mismo año de 1867.

III. LA CUESTION DE GOBIERNO: LA LEGALIZACION DEL COLEGIO DE MISIONEROS DE MONS. CLARET

A principios del 1864, Juan María Alfieri, superior general de los juaninos, pretendía restablecer su orden en España. Elevó un memorial a la Reina; se entrevistó con O'Donnell; de todo hizo sabedor al nuncio Barili. El 10 de mayo de 1864, la respuesta del Sr. Nuncio enfrió los entusiasmos del Superior general de los Hermanos de San Juan de Dios ${ }^{164}$. Cierto, si el asunto dependiera de la Reina, podía darse por concluido, pero no era así, amén de que O'Donnell ya no estaba en el poder, había cambiado el Ministerio. Y el Nuncio proseguía sentencioso: para restablecer las 6rdenes religiosas no conviene andar por el camino oficial, «que no conduce a ninguna parte», es preciso formar una congregación secular dependiente del obispo, sin semejanzas con un orden regular, y «nada pedir, ni esperar del gobiemo». También en 1864 y el 17 de agosto, el Sr. Nuncio respondía a Basilio, obispo de Huesca, y dudaba del permiso del gobierno para abrir en la dicha díccesis una casa de Misioneros del Inmaculado Corazón de María; razón: «no forman un orden regular ni

\footnotetext{
16] Arch. Gen. Claretiano, B. A. cap.4. n. 9(3), Serrat-Xifre, Segovia 27 abril 1865; ASV, Congr. Concilio, Relat. Dioec.. Granaten. 370B, 19 septiembre 1869, Bienvenido Monzón Martín y Puente, no menciona la tal congregacion, si Jos Redentoristas en Alhama; F. FERRERO, Las primeras misiones populares de los redentoristas en España (1863-1868), Spicilegium Historicum Congregationis Ssmi Redemptoris, 33(1985)357-451.

162 E. M. VILARASA, Reseña histórica; España (continuación), Revista Católica, 39(1866)71.

163 AMJ, Eclesiásticos, religiosos, leg. 3.760, n. 12,675.

164 ASV, Arch. Nunz, Madrid, 442, tit. 10, n. 1.
} 
pertenecen a las congregaciones aprobadas» 165 . Infeliz parecer del Nuncio; olvidó que la tal Congregación era el Colegio de misioneros de su «amigo» el confesor de la Reina, Mons. Claret, autorizado en $1859^{166}$. Pues, ¿qué era necesario hacer para arrancar del gobierno isabelino la legalización de una orden no concordada? Arduo asunto.

Donde trabucó el mismísimo Nuncio de Su Santidad, Mons. Claret, y sus valedores, salieron del lance con despejo: arrancaron del gobierno isabelino la legalización de su Colegio de misioneros. Cierto, que Mons. Claret anduvo caminos personales, multiplicados por los cambios de gobiemos, y él mismo y sus valedores allanaron el camino jurídico, entorpecido por el parecer del Consejo de Estado ${ }^{167}$. A la postre, todo fue legitimado por «altas razones de gobierno».

En dos tiempos alcanzó su legalización el Colegio de misioneros de Mons. Claret: autorización de los Estatutos en 1859, y concesión de la exención de quintas en 1867. Todo en conformidad con el art. 29 del Concordato, y pedido por las circunstancias de la Iglesia y de la sociedad hispana.

1. El proceso de aprobación de los Estatutos y concesión de la exención de quintas

Arrancar del Gobierno ambos actos administrativos: aprobación de los Estatutos y exención de quintas, exigió volver muchas mañanas a las oficinas del gobierno; más en Madrid, que en Vic y en Barcelona. El padre Claret sugirió nombrar una especie de «agente de preces», que tramitara los asuntos ${ }^{168}$. Trabajoso, aunque no tanto, el papeleo de aprobación de los Estatutos; breve el de la exención de quintas. Y brevísimo fue el lapso de tiempo, que requirió la aprobación civil en Madrid, si comparado con el exigido para obtener la aprobación pontificia en Roma ${ }^{169}$.

a. El iter de la autorización de los Estatutos, diciembre 1857 - julio 1859

\footnotetext{
${ }^{165}$ ASV. Arch Nunz. Madrid, 448, tit. 9, n. 3, San Ddefonso, 17 agosto 1864, Barili-Basilio Gil Bueno, obispo de Huesca; mera noticia, C. FERNANDEZ, La congregación de los Misioneros Hijos del Inmaculado Corazón de Marka.., Madtid 1967, 391-396.

166 Epistolario Claretiano, n. 725, Claret-Barili, San Ildefonso (La Granja-Segovia) 29 de julio de 1859 , permiso para hacer estudios dentro del Instituto.

${ }^{167}$ Apéndice documental, n. 17.

168 Apéndice documental, n. 27.

169 Aprobación civil: 22 de diciembre de 1857 - al 9 de julio de 1859; aprobación pontificia: decretum laudis, 25 de enero de 1858, - al 19 de octubre de 1860; la aprobación definitiva del Instituto y constituciones el 11 febrero 1870, C. FERNANDEZ, La congregación de los Misioneros Hijos del Inmaculado Corazón de Maria.,, Madrid 1967, 535-661.
} 
Se autorizan los Estatutos, e indirectamente la Institución, que rigen. Papeleado el Epistolario claretiano, el iter de esta autorización se antoja largo y difícil ${ }^{170}$. En realidad, no fue tanto como el continuo quejido del padre Claret deja presumir. El Confesor real mal soportaba esperas y dilaciones. A su Regia confesada comunicó que no haría antesalas. Persona era muy poco dispuesta para hacer la fila en los Ministerios, de ahí sus aspavientos e intranquilidades.

Por sus pasos contados tenemos el iter de la aprobación de los Estatutos. La vigilancia y escrúpulo administrativo anota el curso del expediente fijando la salida y entrada de los papeles ${ }^{171}$. A pesar de tal meticulosidad se advierte una ausencia: la petición del segundo informe solicitado al Consejo de Estado ${ }^{172}$.

El 22 de diciembre de 1857, Mons. Claret presentó a la Reina en papel sellado la solicitud de aprobación de los Estatutos ${ }^{173}$. En ese mismo día llegó la instancia al Ministerio de Gracia y Justicia. El oficial la dio, entrada, y anotó el ejemplar impreso anejo ${ }^{174}$. Formado el expediente, el Ministerio en el mes de febrero cursó la orden de remitirlo al diocesano de Vic, sede de la Congregación, para solicitar su informe; oficio del 25 de febrero, y día de salida del expediente ${ }^{175}$. La diócesis de Vic estaba vacante. El Vicario capitular redactó su informe el 11 de marzo del 1858176. Recibido en Madrid, de nuevo, el 22 de abril, el expediente salió para Barcelona: había de ser examinado por el gobernador civil ${ }^{177}$. En estos primeros meses el padre Claret, siempre impaciente, no fue capaz de seguir el curso del expediente. A principios del mes de mayo supone todavía los Estatutos en el obispado de Vic, y da órdenes para que se despachen luego ${ }^{178}$. Y no hay tal. Ya se habían despachado, vueito a Madrid, y expedidos a gobernación de Barcelona, donde se hallaban. Presto el padre Claret corrigí su error. El 21 de mayo repite la misma orden, ahora referida al gobierno civil de Barcelona ${ }^{179}$. Y por segunda vez, es probable que quedara burlado, pues el 29 de mayo el gobernador de Barcelona remitió su informe a Madrid ${ }^{180}$.

${ }^{170}$ Apéndice documental, nn. 7, 10.

171 Apendice documental, n. 22.

${ }^{172}$ Apéndice documental, nn. 19, 22.

173 Apendice documental, n. 2.

174 Apéndice documental, nn. 2, 22; el ejemplar impreso se conserva en el expediente.

${ }^{175}$ Apéndice documental, nh. 4, 22.

176 Apéndice documental, n. 5; V. GUTTARTE IZQUIRRDO, Episcopologio Español (1700-1867).., Anthologica Annua, 39(1992)433-688, n. 911, p. 628, el 18 de abril fue consagrado en Barcelona Juan Jose Castañer Rivas..

${ }^{177}$ Apéndice documental, nn. 6, 22.

178 Apéndice documental, n. 7.

${ }^{779}$ Apéndice documental, n. 8.

${ }^{180}$ Apéndice documental, nn. 9, 22.

Hispania, del Mediterráneo al Adúntico Hispania Sacra 51 (1999) 
Desde la incoación del expediente el 22 de diciembre de 1857, entrega personal a la Reina, no en una ventanilla del Ministerio de Gracia y Justicia, hasta el 29 de mayo de 1858, que fue evacuado en Barcelona, el iter administrativo no ha podido ser más veloz. Y el servicio de correos también. Todos, autoridad civil y eclesiástica y sus oficiales, han superado las urgencias y premuras claretianas. Todos parecen deseosos de apurar tiempos y trámites.

Las dificultades comenzaron en el mes de junio de 1858. Dificultades previsibles, el dictamen adverso del Consejo de Estado. Obstáculo, que nadie superó durante todo el período isabelino ${ }^{181}$. Razón tenía el Señor Nuncio: seguir la vía legal era un imposible, era una vía muerta, que no llevaba a ninguna parte; y lo dijo en 1864, bien amaestrado por la experiencia.

El 10 de junio de 1858 el padre Claret ya ha alcanzado en su marcha al expediente. Cierta es su información: «dentro de 15 días las Constituciones pasan al Consejo de Estado» ${ }^{182}$. Y así fue, pasaron el 28 de junio ${ }^{183}$. El Consejo de Estado maduró el asunto, y se dignó remitir su informe al Ministerio de Justicia el 8 de octubre ${ }^{184}$. ¿Influyó en esta tardanza el cambio de Ministerio? ${ }^{185}$. No es probable, pues el dictamen del Consejo de Estado siempre fue negativo bajo toda suerte de Ministerios ${ }^{186}$. Habida cuenta de los precedentes, nada hacía suponer un informe positivo ${ }^{187}$. Negativa más lacónica que en otros casos semejantes: «No procede por ahora, conceder la autorización solicitada»188. Resolución contraria del Consejo de Estado, que pudiera ignorar el padre Claret el 15 de octubre de $1858^{189}$.

La negativa del Consejo de Estado cerró en el mes de octubre de 1858 la vía legal del expediente; vía muerta, sin posibilidad de tomar una decision, ni a favor ni en contra. Y cerrado también estaba el portillo de la esperanza: «no es posible por ahora, pero se tendrá en cuenta llegado el momento oportuno». Contra esta oposición del Consejo de Estado se habian estrellado todas las solicitudes. Y archivado el expediente no había forma ni manera de seguir adelante.

En esta situación de impotencia se alcanzó el mes de marzo de 1859. El padre Claret ya estaba impaciente de la cólera y de las bernardinas que le daban.

181 El caso de los redentoristas, Supra II. La cuestión jurídica... 3. La clausula de la tercera orden.. a. Las nterpretaciones.

182 Apéndice documental, n. 10.

183 Apéndice documental, n. 11.

184 Apéndice documental, nn. 13, 22.

185 Apéndice documental, n. 12.

186 Supra, II. La cuestión jurídica.. 3. La cláusula..

187 Supra, II. La cuestión jurídica.. 3. La cláusula.

188 Apéndice documental, n. 13.

189 Apéndice documental, n. 14. 
Tiene palabras descomedidas contra la Santa Bula; y aún reniega el día en que pidió la aprobación de los Estatutos. En su desazón descubrió la causa de la negativa del Gobierno: «se avergienzan de dar una disposicion a favor de una Congregación, que ellos quisieran no hubiese ninguna y temen ser silvados de sus colegas» ${ }^{190}$. Juicio duro en extremo, emitido por quien no gustaba hiciesen de él un dominguillo. No imaginaba, que la solución final estaba a la vuelta de la esquina, de un par de meses.

Cerrado el paso al expediente por la vía legal, en el mes de abril de 1859 se abrí la vía personal de O'Donnell. El padre Claret dió unas misiones en Madrid, detuvo la revolución, y el Duque de Tetuán se mostró muy satisfecho ${ }^{191}$. Empero, no bastaban los quereres de la Reina, y del Presidente de Gobierno, preciso era rebatír la argumentación jurídica contraria del Consejo de Estado. Y se hizo.

Es muy probable, que fueran estos personales quereres quienes dieran la orden de ataque contra la argumentación jurídica del Consejo de Estado. En el mes de mayo de 1859 toda la batería del Consejo de Estado quedó silenciada. Los valedores del padre Claret en el Ministerio de Gracia y Justicia redactaron un informe favorable, que desautorizó el contrario del Consejo de Estado ${ }^{192}$. Y tan convincente fue, que el 15 de junio el padre Claret recibió la noticia de la pronta y favorable resolución del expediente ${ }^{193}$. Había sido superado el obstáculo del Consejo de Estado. ¿Supo el Consejo la refutación de su informe? El 19 de junio, el Ministerio solicitó un nuevo informe del Consejo ${ }^{194}$. Tres días le bastaron para reafirmar su negativa, que bis6 mediante oficio el 22 de junio ${ }^{195}$. Oposición inútil. El 9 de julio, Fernández Negrete de Real orden comunicaba al obispo de Vic la aprobación de los Estatutos, cuya copia pasó al interesado, Mons. Claret ${ }^{1 \%}$.

190 Apéndice documental, n. 15, sobre la bula: «¡Ojalá se retirara la bula de España, que antes se llamaba y era una gran gracia y en el dia es una grande calamidad y desgracia! Quisiera Dios que en esto fuéramos como los dernás vecinos, en que no hay bula; pero dudo que se quite porque Roma cobra 12.000 duros que sirven para el Vaticano y san Juan de Letrán; y el Gobierno cobra lo demás...»; bien informado está el padre Claret, M. BASSo, I privilegi e le consuetudini della Rev.da Fabbrica di San Pietro in Vaticano (sec. XVI-XX), Roma 1987, 106-110, redditi delle crociate, el dinero de la Cruzada hispana mantuvo en pié la fábrica de San Pedro; J. POSTIUS Y SALA, El codigo canónco aplicado a España.., Madrid 1926, pp. 551-554, nn. 524-528 Comisaría general de Cruzada.

${ }^{191}$ Apéndice documental, n. 16.

192 Apéndice documental, n. 17.

193 Apendice documental, n. 18.

194 Apéndice documental, n. 19, Real orden comunicada el 19 del corriente.

195 Apéndice documental, n. 19.

196 Apéndice documental, nn. 20, 21, 22.

Hispania, del Mediterráneo al Atlántico Hispania Sacra 51 (1999) 
Ya sosegado, el 13 de julio, desde La Granja de San Ildefonso (Segovia), real sitio veraniego, el padre Claret comunicaba al Director General de la Congregación, José Xifré, los trabajos sufridos para conseguir la aprobación ${ }^{197}$. Tolérese su encarecimiento. Los cambios de Ministerios no babrían sido tan decisivos como la firme negativa del Consejo de Estado ${ }^{198}$. Y el 29 de julio, todavía en La Granja, notificó a Barili la aprobación del gobierno, y solicitó que los aspirantes a misioneros pudieran concluir sus estudios «en la misma Congregación bajo la dirección y enseñanza del sujeto que señale el Superior de la misma... ${ }^{199}$.

b. El iter de la exención de quintas, octubre 1866 - enero 1867

Muy breve. Conseguida la aprobación del Instituto, obtener la exención de quintas para sus miembros no era dificultoso en extremo. Conceder esta gracia a los miembros de los Colegios de misioneros, para Ultramar, ya se había discutido y decidido en 1848, antes de firmar el Concordato ${ }^{200}$. En 1850 los misioneros de la casa-misión de Vic solicitaron la participación de esos privilegios $^{201}$. No fue posible.

Corto fue el camino andado para obtener la exención de quintas. Tampoco faltaran las impaciencias y desabrimientos de Mons. Claret. Es probable, que ni hubiera consultas sobre el caso en el ahora ministerio de Gobernación. El 24 de septiembre del 1866 el Director General, José Xifré, había expuesto a Mons. Claret la necesidad de obtener la exención de quintas ${ }^{202}$. El 19 de Octubre, Mons. Claret elevó una petición a la Reina. Después comunicó personalmente con Narváez en su domicilio particular. Recibio muy buenas esperan$z^{203}{ }^{203}$ ¿Cuándo dirigí́ el Director General, padre Xifré, su exposición al ministerio de Gobernación? ${ }^{204}$.

\footnotetext{
${ }^{197}$ Apéndice doctumental, n. 23.

198 Estadistica del personal y vicisitudes de las Cortes y de los ministerios de España.., Madrid $1880,354-377$.

${ }^{199}$ Epistolario claretiano, n. 725.

200 Diario de sesiones de Cortes. Legislafura 1847 a 1848, Madrid 1877, II, 973-1111; J. Postrus Y SALA, El código canónico aplicado a España.., Madrid 1926, pp. 435-446, pp. 703-704, n. 679; p. 708 , n. 682, inmunidad personal del servicio militar; M. MARTINEZ ALCUBILLA, Diccionario de la administración española, Cuarta edición, Madrid 1887, VIII, 702-774, servicio militar, en p. 752, nota 11 la Real orden del 30 diciembre de 1882, que la concede a los Misioneros Hijos del Inmaculado Corazon de Maria, misiones en Fernando Poo; situación posterior, SECRETARIADO DE INSTITUTOS RELIGIOSOS DE ESPAÑA, Ley de confesiones y congregaciones religiosas. Texto, fuentes y critica en Ilustración del Clero. Primera edición, Madrid 1933, 153-169, servicio militar.

201 Apendice documental, n. 1.

202 Apéndice documental, n. 26.

203 Apéndice documental, n. 26.

204 Apéndice documental, n. 28.
} 
La exención de quintas interesaba al Instituto, y sobre todo a la casa-misión de Segovia, que había rechazado vocaciones por no tener los postulantes cumplido el servicio militar ${ }^{205}$. Otro impaciente más entró en la escena. D. Clemente Serrat, superior de la casa-misión de Segovia; se había trasladado a Madrid en las Navidades de 1866 para abreviar trámites. A tanta solicitud el padre Claret respondió como solía: molestando personalmente al mismo Narváez ${ }^{206}$. Pasadas las Navidades, en el mes de enero, el ministerio de Gobernación cursó la Real orden con la gracia de la exención concedida ${ }^{207}$.

\section{La base jurídica de la existencia legal del Colegio de Misioneros}

Unica es la base jurídica: el art. 29 del Concordato de 1851 . Artículo que exigía a la orden concordada o no concordada la previa aprobación de la Santa Sede. Requisitos mínimos, que no tenía el Colegio de misioneros de Mons. Claret: una «orden», ni concordada, ni aprobada por la Santa Sede. La Real orden de aprobación de los Estatutos no invoca el citado artículo; sí, de forma velada, la Real orden de concesión de la exención de quintas.

a. Las razones jurídicas de la aprobación de los Estatutos, 1859

El dictamen firme y contrario del Consejo de Estado cerraba la instalación de la tercera orden concordada: ila misma para todas las diócesis o diferente a elección de los obispos? El Consejo de Estado había optado por la posición más dura, única orden, y los peticionarios debían esperar la identificación de la orden escogida. Nada hacía prever que los Estatutos del Colegio de misioneros de Mons. Claret obtuvieran la aprobación del gobierno liberal; pues por no tener, el Colegio de misioneros ni aún la aprobación pontificia tenía.

La súplica de Antonio María, arzobispo de Santiago de Cuba, está redactada en los términos precisos ${ }^{208}$. No invoca el Concordato, describe la vida de la Congregación, y se remite a los informes y a la lectura de los mismos Estatutos. Constituciones aprobadas por D. Luciano Casadevall, obispo de Vic, en 1849; tenían una aprobación diocesana.

Suplican la aprobación unos «congregados»: 13 sacerdotes, y 3 hermanos ayudantes ${ }^{209}$. Todos se han unido de forma voluntaria; y queda su voluntaria

205 C. FERNANDEZ, La congregación de los Misioneros Hijos del Inmaculado Corazón de Maria.., Madrid 1967, 322-327, 6. Vocaciones segovianas al Instituto.

206 Apéndice documental, n. 27.

207 Apéndice documental, n. 28.

208 Apéndice documental, n. 2.

${ }^{209}$ Apéndice documental nn. 2, 17, los nombres de quienes las aceptan al final del texto impreso de los Estatutos, pp. 19-20, abre la lista, naburalmente, la aprobación de Antonio María, arzobispo de Cuba.

Hispania, del Mediterráneo al Atlántico Hispania Sacra 51 (1999) 
Congregación bajo la autoridad de los diocesanos como auxiliares suyos, para predicar en el Reino, y procurar la gloria de Dios, la salvación de las almas y la felicidad de los pueblos.

Estos «congregados» han formulado su súplica con grandísima habilidad. Lo de «congregados» recuerda la solución aplicada en Cuba para paliar la extinción de los regulares. No introducen novedad, y su gratuidad aventaja a los congregados cubanos. Una congregación voluntaria, que no constringe con votos a sus miembros, no es regular; incluso será descrita como una especie de cofradía. Su vida común no es bastante para declararla regular. Sus fines coinciden con los exigidos por el art. 29 a las órdenes concordadas. Y aún las supera en un punto: nada cuesta al Gobierno.

En no hallar ningún obstáculo a su aprobación coincidieron el informe eclesiástico del Vicario de Vic, y el político del gobernador de Barcelona. El Vicario capitular de Vic animó su escrito con el encendido elogio de la Congregación y de sus Estatutos, cuyos miembros están unidos por la caridad. Pide una pronta sanción real, «con lo que, sin gravamen del erario ni de los particulares, se hará un bien inmenso a la Iglesia y al Estado» ${ }^{210}$. Más contenido en sus elogios el parecer del gobernador civil de Barcelona, para concluir solicitando también su aprobación: la Congregación de misioneros tiende a «moralizar al hombre», favorece el bien de la sociedad ${ }^{211}$.

Ambos informes, eclesiástico y civil, no apelan al art. 29 del Concordato. Se han limitado a declarar el Colegio de misioneros de Mons. Claret como una congregación secular según se describe en sus Estatutos. Ambos advierten también su utilidad: Congregación misionera muy necesaria para la Iglesia y la sociedad y sin gravamen para el Estado.

El Consejo de Estado en su doble informe, sí apela al art. 29 del Concordato ${ }^{212}$. Y en conformidad con su letra e interpretación, decide que no ha lugar a ser aprobada. Razones:

La Sección es de parecer: que no siendo dicha Congregación de las aprobadas por la Santa Sede, lo cual es requisito indispensable según previene el art. 29 del último Concordato, y teniendo presente que aun en el caso de que lo fuese, no habiéndose hecho aclaración alguna, sobre cual ha de ser la Tercera orden, que además de la de San Vicente de Paúl, y San Felipe Neri, puede establecerse en España conforme se expresa en el artículo citado; no procede, por ahora, conceder la autorización solicitada213.

${ }^{210}$ Apéndice documental, n. 5.

211 Apéndice documental, n. 9.

212 Apéndice documental, nn. 13, 19.

${ }^{213}$ Apéndice documental, n.13. 
Nada que objetar contra la primera razón. Era verdad, la Congregación de Mons. Claret no había obtenido todavía la aprobación pontificia ${ }^{214}$. La segunda era en contra del espíritu del Concordato. Firme negativa del Consejo mantenida en sus dos informes ${ }^{215}$. ¿Era posible refutar las razones del Consejo de Estado? Fue posible y factible desde dentro del mismo Ministerio de Justicia, siendo su mentor el padre Claret. Amén de que la autoridad del Consejo de Estado no era absoluta ${ }^{216}$

La refutación formula las objeciones, y las anula con una interpretación contraria del texto del art. 29, sin forzar la letra y dentro de su espíritu ${ }^{217}$.

La captatio benevolentiae de la refutación comienza recordando los informes favorables del vicario capitular de Vic y del gobernador civil de la provincia de Barcelona. Recoge después en dos puntos las objeciones del Consejo de Estado. Afirma que ha procedido en su negativa con equivocacion; y lo prueba:

- el Consejo de Estado ha supuesto en su negativa que la Congregación de misioneros de Mons. Claret se trate de una orden religiosa. No es así. Se trata de una congregación secular, una especie de cofradía; y se remite al texto de los Estatutos ${ }^{218}$. Y así era en verdad. Y tan voluntaria y tan libre era la Congregacion, que a esa circunstancia se achacó su primerizo lento desarrollo ${ }^{219}$. Sus miembros no emitían ningún género de voto ${ }^{220}$. Cierto que vivían vida común, «y nunca esta circunstancia se tuvo por bastante para inducir la naturaleza monacal ni regular221.

- La letra del Concordato parece prescribir de forma taxativa los planteles de operarios evangélicos, que ayuden a los obispos. Pero no hay tal. Hay libertad para que el Gobierno pueda establecer otras Congregaciones.

214 La vita religiosa nella storia della Chiesa e della Societd, Milano 1997, 863-864; El ordenamiento de los institutos de votos simples según las Nomae de la Santa Sede (1854-1958) (Studia Urbaniana, 42), Roma-Madrid 1993, 95-114.

215 Apéndice documental, nn. 13, 19.

216 P. de LA SOTA Y LASTRA, «Ley de organización y atribuciones del Consejo de Estadon, en Colección de escritos sobre materias eclesidsticas, Madrid 1871, 157-170.

217 Apéndice documental, n. 17.

218 Apéndice documental, nn. 17, 22.

219 J. XIFRE, Crónica de la congregación de los Misioneros Hijos del hmaculado Corazón de Marta, Anales de la Congregación.., 15(1915)305.

220 Apéndice documental, n. 17.

221 Apéndice documental, n. 17. 
En resolución:

«la Seccion opina que si el Gobiemo de S. M. juzga útil la fundación que se pretende, no hay inconveniente que le impida. Esto ha de decidirse por elevadas razones de gobiemo ${ }^{222}$

Con mucha habilidad la refutación ha planteado la cuestión aprovechando la naturaleza secular del Colegio de misioneros de Mons. Claret. Un liberal nato no haría escrípulo, porque una institución no fuera aprobada por la Santa Sede, la Corte de Roma, al contrario 223 . Y la «utilidad» del Colegio de misioneros ha favorecido la interpretación más fiel del espíritu del Concordato: las órdenes concordadas se ha de crear y mantener. Es taxativo, pero no excluye, que el gobierno pueda crear otras convenientes y útiles para alcanzar los fines previstos por el mismo art. 29; y más cuando no suponen carga alguna para el erario.

¿Quién inspiró a los funcionarios de Ministerio de Gracia y Justicia esta interpretación? No sería mucho imaginar, si la apadrinamos al mismo Mons. Claret. En la súplica de aprobación, suya y de los «congregados», se describe una voluntaria congregación secular ${ }^{224}$. La ausencia de votos fue una medida necesaria por las «circunstancias de los tiempos», declaró su Director General, padre Xifré22s. Aunque, era un género de vida tan perfecto, que el dicho Director General retenía con orgullo «como la de cualquier instituto de votos solemnes»226. Explicar estas circunstancias desazonó como de costumbre al

222 Apéndice documental, n 17; n. 22, «Atendidos el favorable informe de las autoridades civil y Ecca. de la provincia y teniendo presente que del contesto de los estatutos presentados y cuya aprobación se solicita de V. M. no resulta cosa que sea contraria a las prescripciones legales vigentes, toda vez que no puede llamarse orden monástica la congregación del Inmaculado Corazón de Maŕa cuyos congregantes se reunen sin quedar ligados por votos sagrados que los impidan separarse como les convenga, el Negociado estima, que con las modificaciones que exigen las circunstancias presentes después de la extinción de los regulares y señaladamente en el art. 45 del capit. $8^{\circ}$ [de las constituciones presentadas] y en cuanto se ordena por el capítulo 16 de los Estatutos, cuya aprobación se pretende, pudiera V. M. dignarse prestar su Soberana autorización para el Establecimiento de la Congregación del Inmaculado Corazón de Marfa que dedicándose a hacer misiones puede contribuir a mejorar las costumbres públicas».

223 Supra, II. La cuestion juridica. prácticamente toda ella.

224 Apéndice documental, n. 2.

$225 \mathrm{~J}$. XIFRE, Crónica de la congregación de los Misioneros Hijos del Inmaculado Corazón de Marfa, Anales de la Congregación.., 15 (1915) 226, «Estaban en aquella Época eliminados de España Ios Institutos religiosos, sin que se permitiese la restauración ni formación de alguno con semejante carácter. Fue por lo mismo indispensable redactar los Estatutos de tal modo que la autoridad civil no destruyese la obra. Se omitió en ellos todo vínculo obligatorio de parte de los individuos hasta que cambiasen las circunstancias».

226 J. XIFRE, Crónica de la congregación de los Misioneros Hijos del Inmaculado Corazón de Maria, Anales de la Congregación.., 15(1915)305. 
impulsivo padre Claret, que hubo de «pinchar» en las oficinas, y deshacer: «las interpretaciones de los escribas y fariseos.. que todo lo enredan» ${ }^{227}$. Y esta interpretación del art. 29, distinguiendo entre lo taxativo y lo libre, fue mantenida por el Gobierno en 1868; y declarada después la «más natural» "228.

El padre Claret había fundado su Colegio de misioneros antes del Concordato, y quería los tales colegios para toda España. Para Cuba también. El art. 29 del Concordato autorizaba al diocesano a establecer colegios de misioneros en su diócesis. Y con este ardor misionero e interpretación del Concordato Mons. Claret alentó la fundación de los Redentoristas en Huete. El padre Claret era muy devoto de san Alfonso María de Ligorio hasta el punto de haberlo incluido entre los compatronos de su Congregación ${ }^{229}$. En 1862 tuvo noticia de: «las Reglas de la Congregación que fundo S. Ligorio, que me han gustado mucho»; y aún de ellas hizo un extracto ${ }^{230}$. En 1865 los Redentoristas, ya en Huete, parecían sentir lo precario de su situación. Mons. Claret, presente en Roma en noviembre de 1865, visitó su padre general, Mauron. El entusiasmo y aclaraciones del Arzobispo de Trajanópolis deshicieron dudas y reafirmaron decisiones: para afirmarse, y legalmente en España, bastaba ponerse bajo la protección del diocesano como sus misioneros ${ }^{231}$.

\footnotetext{
${ }^{227}$ Apendice documental, n. 14. 1902.

228 A. LOPEZ PEALES, El derecho y la Iglesia.., Madrid 1911, 477, con una nota de Ramplla del

229 Constituciones para los Misioneros de la Congregación del lnmaculado Corazón de María ordenadas por el Excmo... D. Antonio Marla Claret, arzobispo de Cuba y fundador de la misma, y aceptadas por sus individuos con el beneplacito del llumo.. Luciano Casadevall, obispo de Vich, el año 1849. Nuevamente adicionadas por el dicho Sr. Arzobispo y firmadas por los interesados en el afto de 1857, Librera religiosa, Barcelona 1857 , cap. I, $1^{\circ}$; es el texto entregado para su aprobación, se encuentra en AMJ, Eclesiásticos. Religiosos, leg. 3.760, n. 12.718.

230 Epistolario Claretiano, n. 1003, Claret-Xifre, Madrid 6 diciembre 1862; n. 1005, Claret-Xifré, Madrid, 13 diciembre 1862; n. 1069, Claret-Xifré, Madrid 22 noviembre 1863.

231 F. FERRERO, Las primeras misiones populares de los redentoristas en España (1863-1868), Spicilegium Historicum Congregationis Ssmi Redernptoris, 33(1985)357-451, 412, II. La Comunidad de Huete (1864-1868), 1. Extracto de las cartas del P. N. Mauron (Roma, 18 XI 1865) y del P. V. Loyódice (Huete, 26 XI 1865) sobre la actitud de S. Antonio María Claret ante la fundación de los Redentoristas en España. La carta del p. Mauron, «leri l'altro è stato da me Mons. Claret, arcivescovo di Traianopoli, che ora sta in Roma e mostra di esserci molto affezionato e pare contentissimo di vederci in Spagna. Riguardo alla nostra permanenza, mi disse che non si era da temere, che tocca al Vescovo di Cuenca a prendere la nostra difesa, e dichiararsi, in caso di bisogno, Missionarii della sua diocesi, tanto più che il Vescovo, in forza del Concordato, ha diritto di avere pel ministero due case religiose. Questa è stata sempre la mia idea e la vedo confermata da Mons. Clarets. La carta del p. Loyódice es un continuo elogio del «Apostolo di Spagna, un vero imitatore di S. Alfonso... io posso dirle che ci è affezionatissimo fin dal nostro arrivo a Madrid».
}

Hispania, del Mediterráneo al Atlántico

Hispania Sacra 51 (1999) 
b. Las razones jurídicas de la exención de quintas, 1867

La Real orden de aprobación de los Estatutos no declara la base jurídica: la Reina ha accedido a la solicitud del Arzobispo de Cuba ${ }^{232}$. En cambio, la Real orden de la exención de quintas la permite suponer. Describe el Instituto en los términos de una congregación secular al servicio de los obispos, y abierta a Ultramar. No era necesario añadir más para obtener la exención de quintas: se trata de un colegio de misiones. Una añadidura de gracia también, porque el Colegio de Mons. Claret no tiene misiones asignadas en Ultramar.

En ambos casos, aprobación de Estatutos, y exención de quintas, común es la base jurídica; el Colegio de misiones es una congregación secular. Razón, que desbarató toda la artillería del Consejo de Estado, y que alegará el padre Xifré al solicitar su reinstalación en $1875^{233}$. El Colegio de misioneros de Mons. Claret: «no es orden monástica para lo cual según la verdadera jurisprudencia y sana teología se requiere esencialmente clausura y votos solemnes como los hacen los Franciscos.. y que para no deshacerse tan fácilmente se contenta con votos simples y en consecuencia de fácil dispensación.. además nada piden para su manutencion». En 1875, los miembros de Colegio de misioneros claretianos, ya tienen votos, pero votos simples. No son orden regular. No ha cambiado su identidad de congregación secular.

3. Las circunstancias de la legalización del Colegio de misioneros claretianos

Refutado el informe negativo del Consejo de Estado, quedó despejada la vía legal: era posible aprobar los Estatutos y Colegio de Misioneros de Mons. Claret. Que en la práctica se aprobaran, la Sección de Gracia y Justicia lo encomendó a una prudente decisión de gobierno: «Esto ha de decidirse por elevadas razones de gobiemo" ${ }^{234}$. Razones de gobierno, que también se tuvieron en la concesión de la exención de quintas.

a. Las posibles «elevadas razones de gobierno» para aprobar el Colegio de misioneros

La Unión Liberal de O'Donnell, 1859, aprobó los Estatutos del Colegio de misioneros de Mons. Claret. El gobierno moderado de Narváez, 1867, le concedi6 la exención de quintas. Las fechas indican una situación política diferente. La primera vencido el Bienio progresista, y la segunda consumiéndose el tiempo

\footnotetext{
232 Apéndice documental, n. 20. M. ADDRIZZA, Biografía del Reverendisimo Mauron. Introduzione e note di Giuseppe Russo, Spicilegium Historicum Congrefatiomis Ssuri relemptoris, 46 (1998) 403-428.

${ }^{233}$ AMJ, Eclesiásticos, Religiosos, leg. 3.760, n. 12718, Madrid, 21 de junio de 1875.

${ }^{234}$ Apéndice documental, n. 20.
} 
isabelino y en franca decisión de aplicar el Concordato. Diversas, y convergentes, fueron en ambos casos las «elevadas razones de gobierno». Y siempre constante la cargante tenacidad de Mons. Claret, el patrocinio dispensado por la Reina a su Confesor y Padre, y la paciencia del jefe de Gobierno de turno.

Las informaciones, que el nuncio, Barili, sirvió a su señor Antonelli sobre la Unión Liberal en 1858, sin ser halagüeñas, prometen la posibilidad de un arreglo $^{235}$. Empero, los pareceres del Nuncio sobre la situación política no permiten entrever el Convenio adicional del 25 de marzo de 1859. A pesar de ello, en 1859 y bajo la Unión Liberal «razones elevadas de gobiemo», sí las había para aprobar el Colegio de Mons. Claret. Y en 1867 bajo el gobierno moderado de Narváez también. Pocos trabajos costó la exención de quintas. Muy favorable el ambiente político ya determinado a aplicar el Concordato.

En el primer semestre de 1859 la Unión Liberal firmó el Convenio adicional con la Santa Sede. Una forma de reparar los desaguisados del Bienio progresista ${ }^{236}$. En ese mismo semestre el Gobierno aprobó una fundación de Mons. Claret, la Academia de San Miguel, sus Estatutos y la misma Institución ${ }^{237}$. Con esta Academia el padre Claret se había propuesto acabar con la ausencia de la clase intelectual católica en la sociedad isabelina; sus miembros, cultivando las ciencias y las artes, se proponían con todas sus fuerzas insuflar el espíritu cristiano en la sociedad isabelina. Propósitos, que no dejaban de tener una grande significación política. Amén de esta fundación, la actividad misionera de Mons. Claret en esos mismos meses había detenido la revolución; sus misiones «moralizaban al pueblo». La «moralidad» es un concepto fundamental en esta sociedad; se pide a todos, comenzando por el Trono ${ }^{238}$.

${ }^{235}$ ASV, Segr. Stato, Spagna. a. 1858, rubr. 249, basta papelear los despachos remitidos a Antonelli a principios del mes de julio de 1858 , fasc. 2 , ff. $85-85$, 1 de julio, todo está expuesto a graves peligros; ibid., ff.85-87, 4 de julio, parece que la Unión Liberal está en buenas disposiciones con la Santa Sede; ff.106-110, 7 de julio, dice haberse entrevistado con el ministro de Gracia y Justicia, Sr. Fernández Negrete, hombre honesto, íntegro, religioso, pero parece un tanto extraño y tal vez no hace injuria a la opinión de loco. Los socialistas corrompen el vulgo. Todos se engañan unos a otros.

236 J. PostiUS Y SALA, El código canónico aplicado a España.., Madrid 1926, pp. 286-304, nn. 387-389, con los textos.

${ }^{237}$ S. RITUUM CONGREGATIO, Vicen. Beatificationis.. Antoniü Mariae Claret.. Positio super virtutibus, Romae 1915, I, 238-239, la aprobación de la Academia; Epistolario claretiano, nn. 680, 1725, 1747.

238 J. RiCO Y AMAT, Diccionario de los polfticos o verdadero sentido de las voces y frases mas usuales entre los mismos.., Madrid 1855, 39, altar y trono: conciso y expresivo programa político de los absolutistas modernos, el canto de guerra de los realistas del afio 24 «son dos verdaderas necesidades sociales.. despojado el primero de toda preocupación e interés mundano, y alumbrado el segundo por el sol de la justicia y de la moralidad.

Hispania, del Mediterráneo al Atlántico

Hispania Sacra 51 (1999) 
Las casas-misión eran «centros de moralidad», y el Colegio de Mons. Claret se contaba entre ellos ${ }^{239}$.

Razones personales, pues sí también las había y muchas. Las pullas progresistas zaherían la Unión Liberal, penitenta del padre Claret. Y la Reina, penitenta verdadera del padre Claret, nada dejó de revolver por él ${ }^{240}$. ¿Intervino el interés de la Madre Sacramento, amiga de la Reina? Los Estatutos de sus Señoras Adoratrices fueron aprobados un 8 de julio de $1859^{241}$.

La aprobación del Colegio de misioneros claretianos hubo de pagar la gabela a los progresistas y a su opinión pública. El mismo Fernández Negrete afirmó en 1861, «que el gobierno no ha aprobado todavía ninguna nueva orden, a pesar de poder hacerlow ${ }^{242}$. Y los mismos Misioneros comunicaron al obispo de Huesca, que no era conveniente propalar su aprobación para no alertar a la opinion liberal ${ }^{243}$.

\section{b. La necesidad que tenía de su legalización el Colegio de misioneros}

Ya en 1850, apenas fundado el Colegio de misioneros de Vic, su primer superior, Esteban Sala, trabajo para obtener los privilegios de los Colegios de Misioneros de Ultramar ${ }^{244}$; magnífica prueba de la existencia de una firme voluntad inicial de afirmación y de crecimiento. Evidente, que los Misioneros de Vic no podían alegar título alguno para obtener tales privilegios, exención de quintas incluida.

Obtener la exención de quintas era condición necesaria para recibir vocaciones jovenes y asegurar la vitalidad del Instituto ${ }^{245}$. En caso contrario los

239 El ejemplo de la casa-mision de Segovia, ASV, Congr. Concilio, Relat. Dioec.. Segovien, 735, Segovia 11 de abril de 1862, en 3. a, de clero saeculari, informa sobre la casa de misiones, la respuesta del 23 de abril de 1862 alaba la domus sacerdotum, que se dedican a predicar las misiones; se repite en Segovia 17 de diciembre de 1865 en cap. 2. 9, el obispo dice poder ayudar a mantener la domus missionariorum.

240 No obstante, F. SuAREZ, Vida y obra de Juan Donoso Cortés, Pamplona 1997, 588, en dos años secretario de la Reina «no pudo... influir lo más mínimo sobre su caracter, ni tampoco Antonio María Claret en los años que fue su confesor pudo gran cosan. Juicio, en lo que toca al padre Claret, pudiera ser inexacto.

241 SANTA MiCAel a del SaNTISIMo SACRAMENTo, Autobiografia, Madrid 1992, 15-16 aprobación del diocesano, 28 septiembre 1858, aprobación civil, 8 julio 1859, mera noticia; A. BARRIOS MONEO, Mujer audaz. Santa Micaela del Santisimo Sacramento. Su vida, sus empresas..., Madrid 1968, 326, la aprobación civil, noticia en nota 102, «costó mucho tiempo y trabajo», sin más.

242 CONGRESO DE LOS DIPUTADOS, Apuntes para el estudio del proyecto de ley.., Madrid 1906, I, 635-637, Legislatura 1861-1862, Senado contestación al discurso de la Corona.

243 Apendice documental, n. 25; V. GUTTARTE IZQUIERDO, Episcopologio Español (1700-1867).., Anthologica Annua, 39(1992)433-688, n. 931, p. 632, Basilio Gi1 Bueno

244 Apendice documental, n. 1.

245 Las primeras vocaciones al Colegio de misioneros lo son de sacerdotes formados; después llegan vocaciones de jóvenes para clérigos o hermanos ayudantes; Clemente VIII había seffalado el 
posibles ocho años de servicio militar comprometían su crecimiento ${ }^{246}$. Conseguida la exención, el Director General, José Xifré, se apresuró a notificarla al nuncio Barili: «es el grano para crecer el Instituto; a Dios sean las gracias ${ }^{247}$. Y cierto era que la exención urgía, pues habida entre las manos, un mes más tarde, en marzo de 1867 , comenzó su uso y disfrute en la casa-misión de $\mathrm{Vic}^{248}$. No es preciso encarecerlo más.

¿Se tenía necesidad de la aprobación civil de los Estatutos y de la institución? El padre Claret ha sido canonizado, empero no dejó de tener sus momentos de cólera. Fuerte uno de ellos hasta presumir que: «donde pone la pluma el delgado papel rasga». Colérica su carta al S. D. José Xifré P., fechada el 10 de marzo de 1859; escribía en Madrid donde ahora «no es llorar», sino «enfurecerse» 249 . En esta carta embistió contra lo «divino y lo humano»: desamortización, bula de la Santa Cruzada, y contra el Gobierno, que no aprobaba los Estatutos. Tan encendido estaba, que aún renegó de la tal aprobación: «pero yo le debo decir que como la Congregación ya iba marchando por si misma sin tal aprobación, no era menester ni era prudente el procurarla, pues que atendida la impiedad y la guerra que el Gobierno hace a la Iglesia, más pronto alcanzaremos un decreto de exterminio, que una sanción de aprobación». Y continuaba entre ayes, pésetes, y reniegos.

Cuando llegó la aprobación de los Estatutos en el mes de julio de 1859 sosegó el espíritu de Mons. Claret, y se enardecieron aún más sus ánimos misioneros. Ya no escribe desde Madrid, sino desde el Real Sitio de San Ildefonso en La Granja a un largo paseo de Segovia, de sus misioneros del convento de San Gabriel. El 6 de agosto de 1859 dio noticia a D. Antonio Barjau de sus misiones y ejercicios en La Granja, y en Segovia. Y «los misioneros de Vich van prosperando mucho»; razones: «el Gobierno ha aprobado sus constitucio-

\footnotetext{
límite de los 20 años para los religiosos laicos, y no más de 25 para los clérigos, CLEMENTE VIII, decr. Cum ad regularem, 19 marzo 1603, GASPARRI -SEREDI, I, n, 189, \$4; legislación que se modifica, A. M. ClaReT, «Instrucción importantísima para los aspirantes a la Congregación de misioneros del Inmaculado Corazon de María», en Miscelánea interesante.., Barcelona 1865, 323-331, Requisitos 0 condiciones para ser admitido en clase de misionero sacerdote, ...4 ${ }^{\circ}$ Hasta los treinta affos pueden pretender los que tengan las cualidades en una medianía; de treinta a cuarenta se necesitan cualidades superiores, y de cuarenta arriba se requieren cualidades extraordinarias... Requisitos o condiciones para ser admitido en clase de hermano ayudante, $4^{\circ}$ Estar libre de quintas y edad conveniente según lo dicho para eclesiásticos.

246 M. MARTINEZ ALCUBLlLA, Diccionario de la administración española, Cuarta edición, Madrid 1887, VIII, 702-774, servicio militar; A. LOPEZ PELAEZ, El derecho y la Iglesia.., Madrid 1911, 296-297, servicio de las armas, los clérigos exentos, pero no los seminaristas, que por lo general, no podían redimirse por dinero; 297-300, Servicio militar obligatorio; las leyes del reemplazo se sucedieron.

${ }^{247}$ ASV, Arch. Nunz. Madrid, 442, sez. XIII, n. 4², Xifré-Barili Vich,1 febrero 1867.

248 Apéndice documental, n. 29.

249 Apendice documental, n. 15.
}

Hispania, del Mediterráneo al Atlántico Hispania Sacra 51 (1999) 
nes, pueden hacer sus cursos literarios en la Congregación» ${ }^{250}$. Con la aprobación del Gobierno en mano Mons. Claret imaginaba una casa-misión de sus Misioneros en el mismo monasterio de El Escorial ${ }^{251}$. Proyectos, que comunicó al superior de sus Misioneros, José Xifré: «y como [el Monasterio] está en el centro de España se podría salir a misiones en todas las direcciones» ${ }^{252}$. Exulta el animo de Mons. Claret en el mes de agosto de 1859. En Vic ya han recibido la aprobación de «nuestras Constituciones. Gracias a Dios». Y recomienda en la propaganda: «no omitan que están aprobadas por el Diocesano, por el Gobiemo de S. M. y por la experiencia». Y así se hizo ${ }^{253}$. No obstante en el 1862 aconsejó moderación, «vayan con cuidado para no meter bulla» ${ }^{254}$. Moderación, que acabará derrotada por el entusiasmo: la aprobación de los Estatutos y exención de quintas se publicarán en los boletines diocesanos, publicaciones oficiales ${ }^{255}$.

Evidente que convenía al Colegio de Mọns. Claret salir de una precaria situación legal y afirmarse como una institución sólida y cuajada. Estaba puesta al tablero su misma vida.

\section{CONCLUSIONES}

Clemente Serrat, (†Segovia 1906), tercer superior general del Colegio de misioneros claretianos, sostuvo con orgullo ser su Congregación la única aprobada por el gobierno liberal isabelino, y en virtud del art. 29 del Concordato. No es necesario contradecirle recordando el ejemplo de los Redentoristas, aprobados para Ultramar. Entusiasta la Revista Católica en 1866 describía el progreso de las misiones y misioneros en España. Congregaciones de sacerdotes, que siguen el ejemplo de los misioneros del arzobispo de Trajanópolis, el misionero padre Claret ${ }^{256}$.

\footnotetext{
250 Epistolario Claretiano, n. 731.

251 Epistolario Claretiano, nn. 733, 734.

252 Epistolario claretiano, n. 735, Claret-Xifré, San Ildefonso (La Granja-Segovia), 12 agosto 1859.

${ }^{253}$ A. M. CLARET, «Instruccion importantisima para los aspirantes a la Congregación de misioneros del Inmaculado Corazón de Maria», en Miscelánea interesante.., Barcelona 1865, tuvo varias redacciones y publicaciones; la primera para los hermanos ayudantes se publica en 1859 antes de la aprobación del gobieno, J.XIFRE, Casa-Mision. Anuncio, Boletín Eclesiástico del Obispado de Vich, 9(1859) 108, «Habiendo creciđo esta Congregación en el número de sus individuos...»

254 Epistolario Claretiano, n. 986, Claret-Xifré, Segovia, 30 agosto 1862

255 Circular del Ministerio de Gracia y Justicia del 12 de julio de 1862, AMJ, Eclesiásticos, leg. 4.038, n. 21.542 .

${ }^{256}$ Revista Católica, 32(1866)71.
} 
¿Qué razones movieron a los gobernantes isabelinos a conceder al Colegio de misioneros de Mons. Claret, cuanto pertinaces a otros negaron? Razones inteligibles en la convergencia de una serie de circunstancias: jurídicas, religiosas, políticas, personales, que avalaron los actos políticos isabelinos.

- Razón de identidad jurídica canónica: el Colegio de misioneros claretianos es una congregación secular, no es una orden religiosa, sus miembros no emiten votos solemnes, aunque vivan en comunidad, no gravan el erario del estado, ayudan a obispos y párrocos. Identidad jurídica en perfecta consonancia con el Concordato y con la mentalidad de un gobernante liberal moderado.

- Razón jurídica concordataria: una congregación secular fundada en ayuda de obispos y párrocos, abierta a Ultramar, y sin gravamen para el estado, se conforma con el art. 29 del Concordato de 1851. La negativa del Consejo de Estado supone en el Colegio de Mons. Claret una orden regular; y entender en forma taxativa la cláusula de.la tercera orden contradice la letra y el espíritu del Concordato.

- Razón de necesidad eclesial: el art. 29 del Concordato había previsto un número suficiente de operarios evangélicos. No los había. El gobernador eclesiástico de Vic convierte su informe en una súplica: el Colegio de misioneros es útil, muy necesario para contrarrestar la inmoralidad, y ocupar el vacío de los regulares.

- Razón política «elevada de gobierno»: el gobernador civil de Barcelona estima muy útil el Instituto para moralizar la sociedad. Y el mismo O'Donnell tiene de ello experiencia en Madrid: las misiones del padre Claret detienen la revolución. La Academia de San Miguel la puede prevenir. «Razón elevada de gobierno» es también no airear la aprobación para no alborotar la grey liberal.

- Razón personal intervención de la Reina y del jefe de Gobierno: cerrada la vía legal, Barili, nuncio de Su Santidad, aconsejaba la vía personal. Es muy probable, que sin la súplica del padre Claret a su regia Penitente, y sus «impertinencias» con O'Donnell, Narváez, y covachuelistas, su Colegio de misiones no hubiera sido legalizado. ¿Intervino también la Madre Sacramento, amiga de la Reina?

Todas estas razones estriban sobre la recia voluntad de vivir que tenían Mons. Claret, el fundador del Colegio de misiones de Vic, y sus misioneros congregados. Tampoco se ha de despreciar la intuición jurídica del padre Claret. Cierto, que había estudiado por conferencia, que no tenía la capacidad de su condiscípulo Balmes, empero repasaba a Devoti todas las semanas, y entre sus ex libris se cuentan revistas jurídicas.

En resolucion, el estudio del art. 29 del Concordato de 1851 no puede prescindir de la legalización del Colegio de misiones de Mons. Claret. Acto del

Hispania, del Mediterráneo al Atlántico Hispania Sacra 51 (1999) 
gobierno isabelino, que rompió la cerrazón jurídica del Consejo de Estado, y desafíó la mentalidad de progresistas y jacobinos. Un ejemplo de interpretación exegética, histórica, y sistemática del art. 29 del Concordato de 1851.

\section{EPILOGO}

Don Fernando de Castro en el discurso de apertura del curso: 1868-1869, en el Paraninfo de la Universidad Central, acercó la ciencia a la revolución. Pues a pesar de una tan noble compañía, la revolución cogió la mano de su antigua compañera, la libertad, y juntas fueron ambas a embestir contra los «hombres improvisados», y a repetir la frailada. La casa-misión de La Selva del Campo, cerca de Reus, de la Congregación claretiana sufrió el habitual y sangriento asalto a los frailes. Despojados de sus aprobaciones, y en peligro su vida los Misioneros del padre Claret se refugiaron en el mediodía de Francia. Con la Restauración volvieron a España. En febrero de 1875 y desde la casamisión de Segovia solicitaron su restablecimiento: volver a la situación precedente. Se revolvieron papeles en el ministerio de Gracia y Justicia, y apareció el expediente del 1857. In continenti el 24 de septiembre de 1875 obtuvieron su restablecimiento. Más trabajoso resultó obtener la exención de quintas ${ }^{257}$. Llegó en 1882, y con ella el natural destino de Ultramar: Fernando Poo ${ }^{258}$. Documentos todos muy necesarios cuando se discutió la legalidad de las congregaciones en la bisagra de los siglos XIX y XX.

La Real orden del 9 de abril de 1902 invitaba a los institutos religiosos a «exhibir el documento original por el que se concedió la autorizacion" ${ }^{259}$. Real orden y su precedente Real decreto, que no inquietaron al Colegio de misioneros de Mons. Claret, ya Venerable padre Claret. Bien seguro en su posición, su Director General, Clemente Serrat, exhibió sus papeles y reafirmó el carácter nacional del Instituto, más de la tercera parte de sus miembros eran españo-

${ }^{257}$ Arch. Gen. Claretiano, B. H. cap. 3. n.1.

${ }^{258}$ M. MARTINeZ AlCUBILla, Diccionario de la administración española, Cuarta edición, Madrid 1887, VIII, 702-774, servicio militar, en p. 752, nota 11, la Real orden del 30 diciembre de 1882, que la concede a los Misioneros Hijos del Inmaculado Corazón de María, misiones en Fenando Poo; La formación de la prefectura de Fernando Poo. Missionalia Hispanica, 40(1983)33-61; El primer memorial sobre las Misiones del Golfo de Guinea, presentado por los Padres Claretianos a la S. C. de Propaganda Fide, Missionalia Hispanica, 40(1983)161-182; El Vicariato de Fernando Poo según la relación extraordinaria del 1927, Missionalia Hispanica, 41(1984)125-160.

${ }^{259}$ A. LOPEZ PELAEZ, El derecho y la Iglesia.., Madrid 1911, 479-480, La ley del candado del 27 diciembre de 1910; el 30 de mayo de 1910 se exigió el exacto cumplimiento de la Real orden del 9 de abril de 1902, que a su vez urgía el Real decreto del 19 de septiembre de 1901, inscripción en el Registro de asociaciones; J. POSTIUS Y SALA, El código canónico aplicado a Espafia.., Madrid 1926, pp. 318-325, n. 399, Antecedentes sobre la reforma del Concordato. 
$\operatorname{les}^{260}$. Las razones, que habían justificado su autorización en 1859 fueron esgrimidas en 1902 para explicar el recto sentido del art. 29 del Concordato de $1851^{261}$. Nada temieron de la ley del candado en 1910.

Empero muy por encima de todos los trabacuentas, legales, políticos, y de mentalidad, en esta aplicación del art. 29 del Concordato de 1851 emerge la voluntad de vivir de una casa-misión isabelina. En 1850, al año siguiente de su fundación, se equiparó con los Colegios de misioneros para Ultramar al pedir sus privilegios. Voluntad de vivir, que exigía la protección jurídica, civil y canónica. Voluntad de vivir que venció la prueba de la Revolución del 1868. Por desgracia, fue la única casa-misión isabelina, que en solitario se levantó de entre los muertos en la hora de la Restauración, y se convirtió en un nuevo instituto de votos simples.

\section{APENDICE DOCUMENTAL*}

1

1850 , diciemb́re 16, Barcelona

Antonio Barjau, secretario de Mons. Antonio Claret, arzobispo de Santiago de Cuba, notifica a Esteban Sala, superior de la casa-misión de Vic, las indulgencias concedidas por el Arzobispo. En la postdata el mismo Arzobispo comunica al Superior de la casa-misión de Vic, que no es posible obtener los privilegios del colegio de misioneros de Ocaña. Los misioneros de Vic no son religiosos. Se traslada sólo la postdata. Epistolario Claretiano, n. 159.

P. D. - Lo que me dice de la Casa de Vich, respecto a gozar de los privilegios de Ocaña, etc., se respondió en el Ministerio de Gracia y Justicia que esto presentaba algún inconveniente,

${ }^{260}$ Certificado de existencia legal del Instituto, Anales de la Congregación de los Misioneros Hijos del Inmaculado Corazón de María, 8(1901-1902)450-452, el comento en: Instancia del Rmo. $P$. General [Clemente Serrat] al Sr. Ministro de la Gobemación, Cervera (Lérida) 24 de marzo de 1902, Ibid. 452-456; el primer documento es la aprobación de los Estatutos, ratificada por la RO. del 24 septiembre de 1875, en nota; el segundo: la exención de quintas, 18 enero 1867, reafirmado de nuevo y con «carácter eminentemente nacional», se advierte, con la RO. del 9 de agosto de 1882, misiones en Fernando Poo; y para que surtiera los efectos consiguientes, se preparo un impreso autenticado: DIRECCION GENERAL, Madrid, Buen Suceso, 18, Certificación del Secretario General para ser presentada, 5 de noviembre de 1924, en, Arch. Gen. ClareTiANo. Sec. B. ser. II, cap. 6. n. 9bis.

261 A. LOPEZ PELAEZ, El derecho y la Iglesia.., Madrid 1911, 476-479, Legalidad de las Congregaciones; una actual investigación, C. ROBLES MUÑOZ, Frente a la supremacía del Estado. Los católicos y la crisis de la Restaturación (1898-1913), Anthologica Annua, 34(1987)189-305; $36(1989) 317-490 ; 37(1990) 131-252 ; 38(1991) 229-333$.

Hispania, del Mediterráneo al Atlántico

Hispania Sacra 51 (1999) 
porque los de la Casa de Vich no eran religiosos profesos como los de Ocaña, etc. pero que, no obstante, se propondría ello a la Junta y verían qué respondía, la cual respuesta esperan, y el hermano de D. Juan Lobo, tan luego como la sepa, lo escribirá a usted.....

Todo suyo. Antonio, Arzobispo de Santiago de Cuba.

1857, diciembre 22, Madrid

Antonio María, arzobispo de Santiago de Cuba, y los Congregados, cuyas firmas se encuentran en las constituciones que se adjuntan, pp. 19-20, solicitan su aprobación, y poder continuar así en ayuda de los diocesanos y bajo su autoridad. El texto: Constituciones para los misioneros.. del Inmaculado Corazón de María.. Nuevamente adicionadas por dicho Sr. Arzobispo [Claret] y firmadas por los interesados en el año 1857, Librería Religiosa, Barcelona 1857, 20 pp.

Archivo del Ministerio de Justicia, Eclesiásticos, Religiosos, leg. 3.769, n. 12.718, original; Epistolario Claretiano, n. 577 . .

Sello seco. Sello $4^{\circ}$ año $1857.40 \mathrm{~ms}$.

Señora: Antonio María, Arzobispo de Santiago de Cuba y Congregados, suplicamos sumisos a V. M., que previos los informes convenientes, se digne V. M. otorgarnos, para bien de las almas la gracia de que se aprueben las adjuntas Constituciones, de los Misioneros de la Congregación del Inmaculado Corazón de Marfa; para que la dicha voluntaria Congregación, sometida también a la autoridad de los ordinarios y como auxiliar del clero en las funciones de su santo ministerio, especialmente en la predicación, según las necesidades de los pueblos, pueda en el Reino procurar la gloria de Dios, la salvación de las almas y la felicidad de los pueblos; unidos sus individuos por la observancia de lo que en las mismas constituciones se establece, para el régimen interior de la Congregación.

Gracia que esperamos alcanzar del piadoso y católico corazón de V. M.

Madrid, 22 diciembre de 1857

Señora A. L. R. P. de V. M.

Antonio María, Arzobispo de Cuba

1858 , enero 25, Madrid

El padre Claret solicita a Pío IX la aprobación de las Constituciones.

ASV. Ep. ad Princ. 35. n. 590, original; Epistolario claretiano, n. 590, copia.

1858 , febrero 25, Madrid

El ministerio de Gracia y Justicia remite al obispo de Vic los estatutos de la Congregación del Intraculado Corazón de María, y piđe un informe.

Archivo del Ministerio de Justicia, Eclesiásticos, Religiosos leg. 3.769, n. 12.718, minuta 
Al Ymo. Obispo de Vich. Madrid 25 febrero 1858 [al margen] Nego. $4^{\circ}$. De R. O comunicada remito á V. Y. las adjuntas Constituciones de los Misioneros de la Congregación del Inmaculado Corazón de María a fin de que informe V. E. cuanto estime oportuno y conveniente respecto de la aprobación que de estos estatutos se solicita. Dios.. Fechada idem.

\section{5}

1858 , marzo 11, Vic

Eduardo Teixidor, vicario capitular de la diócesis de Vic, en sede vacante, remite al Subsecretario del Ministerio de Gracia y Justicia un elogioso informe sobre los estatutos de la Congregación de Misioneros del Inmaculado Corazón de María, y solicita la pronta sanción real de la Congregación.

Archivo del Ministerio de Justicia, Eclesiásticos, Religiosos, leg. 3.769, n. 12.718, original.

[Membrete impreso] Gobieno Eclesiástico del Obispado de Vich.

Ylmo. Sor. Examinadas con la debida atención las Constituciones de los Misioneros de la Congregación del Inmaculado Coraźón de María que V. S. Y. se digna remitirme de Rl. orden para informar acerca la aprobación que de ellos se solicita; no puedo menos que manifestar, que en ellas no hay cosa alguna que se oponga a los deberes, preceptos y consejos de nuestra Sacrosanta Religión. Las reglas que se consignan para el régimen y gobierno general y particular de la Congregación, están basadas en la caridad, en esa sublime virtud hija del cielo que por sí solo basta para hacer la felicidad de las almas redimidas con la preciosísima sangre de nuestro Señor Jesucristo.

Los Misioneros del Inmaculado Corazón de María no tienen otras aspiraciones ni les animan otros deseos que los de santificarse a sí mismos con la observancia de las Constituciones, que someten a la aprobación de la Reina Ntra Sra., q. D. g., y de santificar a los demás, procurando a todos con desinterés, el pan del alma por medio de los Stos ejercicios, predicación de la Divina palabra, ensefianza del catecismo y de otras obras de misericordia a que se entregan.

Por una parte, la falta que desgraciadamente se nota en nuestra patria de Ministros del Señor, que puedan dedicarse a la predicación, sin menoscabo de otras atenciones no menos preferentes de tan santo ministerio, por efecto de la supresión de las Comunidades religiosas; y por otra, la inmoralidad, la irreligión, la indiferencia que van minando la sociedad, y que cual huracán furioso brama por todas partes amenazando destruirla, clama a voz en grito por la apremiante necesidad de que el magnánimo y paternal corazón de nuestra Católica Reina y Gobierno tiendan su mano benéfica y protectora sobre una Congregación, que tanto se desvela para neutralizar los proyectos de la impiedad, que todo lo sacrifica para alcanzar la reconciliación, ia fraternidad de los hijos de la Iglesia de Jesucristo y de su felicidad eterna.

Por tanto, lejos de hacer observación alguna contraria a la aprobación de los estatutos que tengo el honor de devolver, ruego a V.S. Y. se digne interponer su poderosa mediación e interesar al Exmo. Sor. Ministro de Gracia y Justicia para que dichos estatutos obtengan la sanción real, con lo que, sin gravamen del Erario ni de los particulares, se hará un bien inmenso a la Iglesia, y al Estado.

Dios guarde a V.S. Y. muchos años.

Vich, 11 marzo de 1858

[firmado y rubricado] Eduardo Teixidor, Vic. Cap.

Ymo. Sor. Subsecretario del Ministerio de Gracia y Justicia.

Hispania, del Mediterráneo al Atlántico

Hispania Sacra 51 (1999) 
1858, abril 22, Madrid

El Ministerio de Gracia y Justicia remite al gobernador civil de Barcelona Ios Estatutos de la Congregación del Inmaculado Corazón de María, para que indique lo que crea oportuno.

Archivo del Ministerio de Justicia, Eclesiásticos, Religiosos leg. 3.769, n. 12.718, minuta.

Al gobernador civil de la Provincia de Barcelona. Madrid 22 abril 1858 [al margen] Negdo. $4^{\circ}$.

De R. O. comunicada remito a V. S. los Estatutos por que piensa regirse y gobernarse la Congregación del Inmaculado Corazón de María, que se proyecta establecer en Vich a fin de que, con devolucion, indique V. S. cuanto estime oportuno y conveniente respecto de la aprobación de estos Estatutos en la parte que a su autoridad incumba.

Fechada idem.

1858, mayo 7, Madrid

Mons. Claret encarga al padre Xifré, recién electo superior de la Congregación, se interese por la suerte del informe pedido al obispado de Vic sobre aprobación de las Constituciones, que se hallará en la Secretaría, «a fin de que se despachen luego..»

Epistolario claretiano, n. 617.

1858, mayo 21, Madrid

Mons. Claret comunica al padre Xifré que las Constituciones ya están para información en el gobiemo civil de Barcelona, y le encarga se interese por su pronto despacho.

Epistolario claretiano, n. 620.

\section{9}

1858 , mayo 29, Barcelona

Respuesta favorable del gobernador de Barcelona. Nada estorba la aprobación de la Congregación de Misioneros.

Archivo del Ministerio de Justicia, Eclesiásticos, Religiosos leg. 3.769, n. 12.718, original.

[al margen] Negdo $4^{\circ}$. Num ${ }^{\circ}$ 5. Manifiesta que pueden aprobarse los estatutos de la Congregación titulada de María, que debe establecerse en Vich.

Exmo. Señor. En cumplimiento de la Real orden de 22 de Abril próximo pasado recibida en este gobiemo el día 10 del actual, tengo el honor de decir a V. E. que en las Constituciones o Estatutos de los Misioneros de la Congregación, titulada de María, no encuentro nada ofensivo al Estado, ni a la Religión. Al contrario, de su lectura se desprende que tienen un fin piadoso; y que lo que tiende es a moralizar al hombre y encaminarlo por el sendero de la virtud; tan lejos de perjudicar, favorece al bien de la sociedad; entiendo que no habra inconveniente en aprobarlos. 
Al efecto, y adjunto devuelvo el ejemplar que a la citada Real orden acompañaba con la comunicación del gobierno eclesiástico de Vich.

Dios guarde a V. E. muchos años.

Barcelona 29 de de mayo 1858.

Exmo. Señor [firmado y rubricado] Fernando [apellido ilegible]

Exmo. Señor Ministro de Gracia y Justicia

10

1858, junio 10, Madrid

Mons. Claret notifica al padre Xifré que dentro de 15 días las Constituciones han de pasar al examen del Consejo Real. La aprobación del Sto. Padre «no tardará en venir». [doc. n. 24]

Epistolario claretiano, n. 626.

11

1858, junio 28, Madrid

El Ministerio de Gracia y Justicia remite al Consejo Real para su informe los Estatutos de la Congregación del Inmaculado Corazón de María.

Archivo del Ministerio de Justicia, Eclesiásticos, Religiosos leg. 3.769, n. 12.718, minuta

Al Vicepte. del Consejo Real.

Madrid 28 junio 1858. [al margen] Negdo $4^{\circ}$.

De R. O. comunicada, remito a V. E. los Estatutos por que piensa regirse y gobernarse la Congregación del Inmaculado Corazón de María, que se proyecta establecer en Vich, a fin de que la sección de Gracia y Justicia del Consejo informe con devolución cuanto estime oportuno y conveniente respecto de la aprobación, que para dichos Estatutos se solicita

Dios guarde..

Fechada idem.

1858, agosto 4, Oviedo

Mons Claret comunica al padre Xifré la esperanza de la aprobación de las Constituciones, pero son muchos los trámites, y ha habido cambio en el Ministerio.

Epistolario claretiano, n. 639.

\section{3}

1858, octubre 8, Madrid

La Sección de Estado de Gracia y Justicia del Consejo Real advierte, que el art. 29 del Concordato no consiente la aprobación de los Estatutos de la Congregación de Misioneros.

Hispania, del Mediterráneo al Atlántico

Hispania Sacra 51 (1999) 
Archivo del Ministerio de Justicia, Eclesiásticos, Religiosos leg. 3.769 , n. 12.718, original

[Al margen] Sección de Estado y Gracia y Justicia. [guión] Señores González, Caballero, Garcia Gallardo, Vaamonde.

De Real orden comunicada en 28 de Junio de 1858 por el Ministerio del digno cargo de V. E., se ha remitido en consulta a esta Sección un expediente, con los Estatutos porque piensa regirse, y gobernarse la piadosa Congregación, que con el título del «Inmaculado Corazón de María» se proyecta establecer en Vich, para que informe lo que se le ofrezca sobre su aprobación. La Sección es de parecer: que no siendo dicha Congregación de las aprobadas por la Santa Sede, lo cual es requisito indispensable según previene el art. 29 del último Concordato, y teniendo presente que aun en el caso de que lo fuese, no babiéndose hecho aclaración alguna, sobre cual ha de ser la Tercera orden, que además de la de San Vicente de Paúl, y San Felipe Neri, puede establecerse en España, conforme se expresa en el artículo citado; no procede, por ahora, conceder la autorización solicitada.

Lo que por acuerdo de la Sección tengo el honor de poner en conocimiento de V. E. con devolución del expediente.

Dios guarde a V. E. muchos años.

Madrid, 8 de Octubre de 1858.

Exmo. Sor.

El Presidente de la Sección

[firmado y rubricado] Antonio González.

Exmo. Sor. Ministro de Gracia y Justicia.

1858 , octubre 15, Madrid

Mons. Claret comunica al p. Xifré que las Constituciones ya han pasado del Ministerio al Consejo supremo se duele de «las interpretaciones de los escribas y fariseos de las oficinas que todo lo enredan». En realidad, el Consejo ya las babía despachado con voto negativo el 8 de octubre [doc. n. 13]

Epistolario claretiano, n. 651.

\section{9, marzo 10, Madrid}

Mons. Claret manifiesta al padre Xifré su disgusto por el punto muerto en el que se halla la aprobación del Instituto shan cambiado tres veces el ministerio.. me han prometido mil veces que se despacharían luego; pero hacen del olvidado y es que se avergienzan de dar una disposición a favor de una Congregación, que ellos quisieran no hubiese ninguna y temen ser silvados de sus colegas». Juicio muy duro, no obstante infra doc. n. 16.

Epistolario claretiano, n. 685. 
1859, abril 7, Madrid

Mons. Claret anuncia al padre Xifré la pronta aprobación de las Constituciones, pues: «El Presidente de Ministros [O'Donnell], me ha dicho ayer que luego despacharía el expediente de nuestras Constituciones; esta muy contento del grande fruto, que Dios ha hecho por mis misiones en esta Corte, porque se han moderado y detenido las masas del pueblo; y así esta dispuesto a hacer cualquier cosa a mi favor̀. Comunica también la aprobación de los estatutos de la Academia de San Miguel, 16 de marzo de 1859; Institución, que será aprobada el 20 de abril.

Epistolario claretiano, n. 688.

[1859, mayo 28, Madrid]

Un informe, sin firma, refuta el parecer de la Sección del Consejo de Real contraria a la aprobación de la Congregación de Misioneros. Se podria suponer del 28 de mayo [doc. n. 22]

Archivo del Ministerio de Justicia, Eclesiásticos, Religiosos leg. 3.769, n. 12.718, original

Sobre el establecimiento de un instituto de misiones que el M. R. Arzobispo de Cuba intenta fundar en Vich.

El M. R. Arzobispo de Cuba solicitó la aprobación de las Constituciones de una Congregación de eclesiásticos misioneros, que pensaba fundar en Vich bajo el título del Inmaculado Corazón de María [doc. n. 2]

Pasados a informe del Diocesano los devolví evacuándolo favorablemente [doc. n. 5].

Lo mismo hizo el Gobernador Civil de la Provincia [doc. n. 9].

Remitidos al de la Sección de Gracia y Justicia y Estado del Consejo, ha opinado, que por ahora no procede de otorgar la autorizacion solicitada [doc. n. 13].

Fíndase $1^{\circ}$. en que no se ha declarado todavía cuál ha de ser la tercera orden que además de los institutos de San Felipe Neri y San Vicente de Paúl puede establecerse en España con arreglo a lo pactado en el art. 29 del Concordato.

Segundo - En que según dicho artículo la orden que se eligiese ha de ser de las aprobadas por la Santa Sede, cuya circunstancias no concurre en la que el dicho Arzobispo de Cuba intenta fundar.

El art. 29. del Concordato dice asf: Art ${ }^{\circ}$. 29. A fin de que en toda la Peninsula haya el número suficiente de ministros y operarios evangélicos de quienes puedan valerse los Prelados para hacer misiones en los pueblos de su Diócesis, auxiliar a los Párrocos, asistir a los enfermos, y para otras obras de caridad, y utilidad pública, el Gobierno de S. M. que se propone mejorar oportunamente los Colegios de Misiones para Ultramar, tomará desde luego las disposiciones convenientes para que se establezcan donde sea necesario, oyendo previamente a los Prelados diocesanos, Casas y Congregaciones religiosas de San Vicente de Paúl, San Felipe Neri y otra Orden de las aprobadas por la Santa Sede, las cuales, servirán al propio tiempo de lugares de retiro para los eclesiásticos, para hacer ejercicios espirituales y para otros usos piadosos.

La Sección opina que si el Gobiemo de S. M. juzga útil la fundación que se pretende, no hay inconveniente que le impida.

Hispania, del Mediteráneo al Atlántico

Hispania Sacra 51 (1999) 
No lo son los que el Consejo alega porque ha procedido con equivocación al emitir su parecer.

Ha supuesto, que el Instituto de que se trata es un orden religioso, y no es así.

Es sólo una Congregación religiosa, una asociación, una especie de cofradía.

Examinando los estatutos se ve que faltan algunos de los indispensables para constituir orden regular, ni aun congregación semi-regular. No hay votos.

Aunque se parece a los ordenes expresados, en cuanto a hacer vida común, nunca esta circunstancia se tuvo por bastante para inducir la naturaleza monacal, ní regular.

El Gobierno pues examinando los Estatutos, verá si le conviene, que en el reino no existen Congregaciones de Sacerdotes que los observen, y si encontrase que es así, no parece haya dificultad para que las autorice.

Verdad, que el arto. del Concordato parece que determina en qué forma han de existir los planteles de donde salgan los ministros y operarios evangélicos de quienes los Prelados han de valerse para hacer misiones y encomendarles otros ministerios, en que ayuden a los párrocos, y que el establecimiento de los institutos citados por el Consejo [sic]. Esto, tal vez, ha dado margen a que opine como lo ha hecho.

Pero observando bien el contexto del dicho artículo se ve que este señalamiento no es taxativo, y que, por lo tanto, aun reponiéndolo, queda libertad para valerse de otros medios, para establecer otras Congregaciones.

Quiere decir que el establecimiento de esas ódenes es obligatorio; pero esta obligación no destruye la facultad de instalar otras, si se creen convenientes y útiles.

Esto ha decidirse por elevadas razones de gobierno.

\section{8}

1859 , junio 15, Madrid

Mons. Claret notifica al padre Xifré, que ha «visto al S. Negrete, ministro de Gracia y Justicia, y me ha dicho que pasado mañana enviará las Constituciones de la Congregación aprobadas".

Epistolario claretiano, n. 707.

\section{9}

1859 , junio 22, Madrid

La Sección de Estado y Gracia y Justicia repite de nuevo su informe del 8 de octubre de 1858, negativo sobre la aprobación. [doc. n. 13]

Archivo del Ministerio de Justicia, Eclesiásticos, Religiosos leg. 3.769, n. 12.718, original

[Al margen] Sección de Estado y Gracia y Justicia. [guión] S. S. González, Pte. Vaamonde

Exmo. Sor. En cumplimiento de la Real orden de 19 del corriente comunicada por el Ministerio de su digno cargo, [doc. n. 22, no aparece registrada] tengo el honor de transcribir a V. E. el informe, que esta Sección elevó al mismo con fecha 8 de Octubre de 1858. [se repite el documento n. 13 con leves modificaciones de estilo]

Dios guarde á V. E. muchos años.

Madrid 22 de Junio de 1859. 
Exmo. Señor

El Presidente de la Sección

[firmado y rubricado] Antonio González.

Exmo. Señor Ministro de Gracia y Justicia.

1859, julio 9, Madrid

Femández Negrete, ministro de Gracia y Justicia, comunica al Sr. Obispo de Vic la aprobación de los Estatutos de la Congregación, fundada por el Arzobispo de Cuba, Mons. Claret.

Archivo General Claretiano, B. H. cap. 6, n. 8, original; [al margen] suplicada la devolución. (firmado y rubricado) $M$. de Arrandiaga, cmf. [No se ha devuelto al archivo donde debiera estar: el diocesano de Vic] Noticia de algunos documentos.., Vich 1861 , p. $3,1^{\circ}$. Aprobación de la Congregación por el Gobierno de S. M.

[Al margen] Negociado $4^{\circ}$.

[estampado el escudo del Ministerio de Gracia y Justicia]

Yllmo. Sor.

Accediendo la Reina (q. d. g.) a la solicitud del M. R. Arzobispo de Cuba, [doc. n. 2] se ha dignado prestarle su soberana aprobación a los Estatutos por que se propone regir y gobernar la Congregación del Inmaculado Corazon de María, establecida en esa ciudad. De Real orden to digo a V. Y. para su conocimiento y efectos consiguientes.

Dios guarde a V. Y. muchos años.

Madrid, 9 de Julio de 1859 [Firmado y rubricado] Fernández Negrete.

Señor Obispo de Vich.

1859, julio 9, Madrid

El subsecretario del Ministerio de Gracia y Justicia comunica y traslada al Exmo.

Claret la R. O. de la aprobación de los Estatutos, enviada al Sr. Obispo de Vic.

Archivo General Claretiano, B. H. cap. 6, n. 8, copia.

[Al margen] Ministerio de Gracia y Justicia. Negociado $4^{\circ}$. Copia del oficio enviado al Exmo Sr. Claret por la aprobación de las Constituciones de la Congregacion del Inmaculado Corazón de María.

Exmo. Señor. El Señor Ministro de Gracia y Justicia dice con esta fecha al R. Obispo de Vich lo que sigue:

«Accediendo la Reina (q. d. g.) a la solicitud del M. R. Arzobispo de Cuba, [doc. n. 2] se ha dignado prestarle su soberana aprobación a los Estatutos por que se propone regir y gobernar la Congregación del Inmaculado Corazón đe Maria, establecida en esa ciudad»

De Real orden comunicada por el expresado Señor Ministro lo traslado a V. E. para los efectos consiguientes.

Dios guarde a V. E. muchos años.

Hispania, del Mediterráneo al Atlántico Hispania Sacra 51 (1999) 
Madrid 9 de Julio de 1859.

El subsecretario. José L. Figueroa [firmado y rubricado].

Sin fecha

Apunte de cancillería de todos los pasos dados para la aprobación de las Constituciones de la Congregación del Excmo. Sr. Claret.

Archivo del Ministerio de Justicia, Eclesiásticos, Religiosos leg. 3.769, n. 12.718. todo de la misma mano salvo una nota final: Cancillería 20.421.

Madrid Diciembre 22/857.

El M. R. Arzobispo de Cuba solicita la aprobación de las Constituciones de los Misioneros de la Congregación del Inmaculado Corazón de Maria, y acompaña un ejemplar impreso.[supra doc. n. 2]

Nota. Deben remitirse estos estatutos a informe del Diocesano de Vich. [firma ilegible] 25 de febrero, conforme la nota, fechada idem [supra doc. n. 4]

Vich, Marzo 11/858.

El Gobernador ecco. devuelve los estatutos e informa favorablemente [supra doc. n. 5]

Nota. Procede ahora que se remitan estos estatutos a informe del gobemador civil de la Provincia.[firma ilegible] 22 de abril, conforme la nota, fechada idem. [supra doc. n. 6]

Barcelona Mayo 29/858. n. 9]

El Gobernador de la Provincia informa favorablemente, y devuelve los estatutos [supra doc.

Nota. Procede ahora remitir estos estatutos a informe de la sección de Gracia y Justicia del Consejo Real. [firma ilegible] 23 [28] de Junio, conforme la nota, fechada idem [supra doc. n. 11]

Madrid, octubre 8/858

La Seccion de Gracia y Justicia del Consejo de Estado devuelve los Estatutos y dice: que no siendo la dicha Congregación del Inmaculado Corazón de María de las aprobadas por la Santa Sede, lo cual es requisito indispensable según previene el art. 29 del ultimo concordato, y aun en el caso de que lo fuera no habiéndose hecho aclaración alguna sobre cuál ha de ser la $3^{*}$ orden que, además de la de San Vicente de Paúl y San Felipe Neri, puede establecerse en España conforme se expresa en el art. citado, no procede por ahora conceder la autorización solicitada.

Nota.

Atendidos el favorable informe de las autoridades civil y Ecca. de la provincia, y teniendo presente que del contexto de los Estatutos presentados y cuya aprobación se solicita de V. M. no resulta cosa que sea contraria a las prescripciones legales vigentes, toda vez que no puede llamarse orden monástica la congregación del Inmaculado Corazón de María, cuyos congregantes se reúnen sin quedar ligados por votos sagrados que los impidan separarse como les convenga, el Negociado estima, que con las modificaciones que exigen las circunstancias presentes después de la extinción de los regulares y sefialadamente en el art. 45 del capit. $8^{\circ}$ [de las Estatutos presentados] y en cuanto se ordena por el capitulo 16 de los Estatutos, cuya aprobacion se pretende, pudiera V. M. dignarse prestar su Soberana autorización para el establecimiento de la Congregación del Inmaculado Corazón de Marfa, que dedicándose a hacer misiones puede contribuir a mejorar las costumbres públicas. [Firma ilegible] 
[al margen de este ́́ltimo párrafo] 28 de mayo [1859] conforme la nota; [al margen, otra mano] Aprobados por S. M. en despacho de 8 de Junio 859. Fechada idem.

Cancillería $\mathrm{n}^{\circ}$. 20.421.

\section{3}

1859, julio 13, Real Sitio de San Yldefonso [La Granja - Segovia]

Mons. Claret describe al Presidente y Director General de la Congregación de Misioneros, padre. Xifré, las dificultades habidas para conseguir la aprobación de las Constituciones. El expediente se perdí y fue necesario formarlo de nuevo. Tal vez se refiera al doble informe, que hubo de evacuar el Consejo de Estado [doc. nn. 13, 19]

Epistolario claretiano, n. 717.

1860 , octubre 19, Roma

El Instituto de Presbíterós seculares misioneros del Inmaculado Corazón de María obtiene el decretum laudis pontificio; la aprobación de las Constituciones se deja a un tiempo posterior.

Noticia de algunos documentos.., Vich 1861, p. 4, $2^{\circ}$ Recomendación de la misma por S. S.

1864, septiembre 20, Huesca

Basilio, obispo de Huesca, comunica al nuncio Mons. Barili la apertura de una casamisión de Misioneros Oblatos en su diócesis. Sólo es necesario el consentimiento del diocesano. Se traslada una parte del texto.

ASV, Arch. Nunz Madrid, 442, original.

... Habiéndome manifestado el Señor Director General de Misioneros Oblatos de María Inmaculada [D. José Xifré], que según las instrucciones, que tienen privadamente del Gobiemo de S. M., pueden instalarse de acuerdo con los Obispos, sin esperar Rl. orden especial, y que bastaba, por tanto, que yo lo hubiera puesto en noticia del Ministerio, como lo hice, hemos resuelto abrir esta Casa-Misión en el mes próximo, previos los ejercicios espirituales a mi clero Diocesano que dará el mismo Señor Director Misionero en dos tantas. También se abrirá al propio tiempo la casa que he dispuesto en Sesa, como sección o auxiliar de mi Seminario Conciliar.

Suplico á V. E. R. sus oraciones...

Q.B. S. M. Basilio, obispo de Huesca [firmado y rubricado].

1866 , octubre 19, Madrid

Antonio María, arzobispo de Trajanópolis, comunica al Sr. D. José Xifré, que ya ha solicitado la exención de quintas deseada. Ha interesado a la Reina, y al Ministro de la Guerra, Narváez. Se traslada una parte del texto.

Epistolario Claretiano, n. 1250.

Hispania, del Mediterráneo al Atlántico

Hispania Sacra 51 (1999) 
J. M. J. S. D. José Xifré Prob. Muy Sr. mío de toda mi consideración y aprecio. Con la presente debo decir a V., que tan pronto como recibí su estimada carta, fecha 24 del pasado mes, en que me indicaba el deseo que tenía de que obtuviese del Gobiemo el que los jóvenes, que entrasen en la Congregación, fuesen exentos de quintas, puse manos a la obra. Lo pedí a S. M., y me contestó favorablemente; y paś mi nota al Ministro de la Guerra, que es Narváez. He vuelto a hablar con S. M. y quedamos en que yo pasaría a verle y hablarle en su casa misma; hoy he ido y me ha dado muchas esperanzas. Encomiéndalo mucho a Dio y a la Sma. Virgen...

1866, diciembre 25, Madrid

Antonio María, arzobispo de Trajanópolis, comunica a D. José Xifré, que también desde la casa-misión de Segovia piden la exención de quintas; le da cuenta de nuevas gestiones. Se traslada una parte del texto.

Epistolario Claretiano, n. 1264.

J. M. J. S. D. José Xifré, Supr. Gl. Muy Sr. mío de toda mi consideración y aprecio. Acabo de recibir su muy estimada carta y le agradezco su buen afecto. En estos días hemos tenido a D. Clemente, que se ha venido para practicar algunas diligencias, a fin de conseguir la huerta de su Casa, y también obtener la exención de quintas de los jóvenes que entren en la Congregación; él y yo hemos hablado con D. Beltrán de Lis, y se le ha entregado una nota. Había ocho días que yo había hablado con S. M. de eso mismo; y también le había dado una nota; y antes tenía ya esperanzas del Presidente Narváez. L. Pujol pretendía lo mismo; yo presenté a S. M. la solicitud y ella la entregó al Sr. Ministro. Conviene que en ésta tengan una persona, que ande con frecuencia por las oficinas, de otra manera se eternizan las peticiones...

\section{8}

1867, enero 18 , Madrid

González Bravo, ministro de Gobernación, comunica al Superior General de la Congregación de Misioneros del Inmaculado Corazón de María la concesión de la exención de quintas a los individuos de la dicha Congregación.

Archivo General Claretiano, B. H. cap. 6, n. 8, copia; Boletín Eclesiástico de la Di6́cesis de Segovia, año XII, jueves 31 de enero de 1867, núm. 5, p. 33

Administración local. Neg. 4. Quintas. Enterada la Reina (q. D. g.) de una exposición dirigida por V. a este Ministerio, solicitando de que se declarasen exentos del servicio militar a los individuos de la Congregación de Misioneros del Inmaculado Corazón de María; teniendo presente, que según las reglas de la expresada corporación los que la componen están obligados con juramento a ser constantes coadjutores de los Prelados de la Iglesia en el ministerio de la predicación, no sólo en la Península, sino en cualquier parte donde sean necesarios sus servicios; $S$. M. se ha dignado acceder a lo solicitado por V. y mandar que a los individuos de la Congregación de que es Superior, se les exima del servicio militar, como comprendidos en los párrafos $3^{\circ}$ y $4^{\circ}$ del articulo 74 de la ley de reemplazos vigente.

De orden de S. M. lo digo a V. para su conocimiento, satisfaccion, y demás efectos consiguientes.

Dios guarde á V. muchos años.

Madrid 18 de Enero de 1867. [firma autógrafa] González Bravo

Al Superior General de la Congregación de Misioneros del Inmaculado Corazón de María.

Hispania, del Mediterráneo al Atlántico Hispania Sacra 51 (1999) 
1867, marzo 11, Vic

Jaime Clotet y Fabré, vice-director de la Congregación de Misioneros, certifica que Don Antonio Cases y Giralt pertenece a la Congregación y resulta eximido del servicio militar en conformidad con el Real decreto del 18 de enero de 1867. Certificación que dos notarios legalizaron. Tal vez sea la prima petición. Una segunda fórmula en p. 68 añade que el Real decreto fue publicado el 30 de enero en el Boletín oficial de la de Barcelona.

J. Clotet. Formulario, n. 20, p. 67, Arxiu Pairal, Vic. N. Inv. 2727, S. 22-1, C. XLIV.

Certificaciones libradas a dos individuos de la Congregación para que les eximieran del servicio militar.

D. Jaime Clotet Presbítero, Sub-Director General de la Congregación de Misioneros del Inmaculado Corazón de María y Superior local de la Casa-Misión de Vich, certifica:

Que D. Antonio Cases y Giralt, hijo de Antonio Cases y Giralt, natural del pueblo de Cedo, provincia de Lériđa, soltero de edad veinte años, sintiéndose llamado de Dios, y previo el đebido consejo entro en la mencionada Congregación el treinta de Agosto de mil ochocientos sesenta y cuatro, y habiendo pasado el affo de noviciado, profesó en la misma el veinte y siete de septiembre de mil ochocientos sesenta y cinco con las formalidades establecidas, según todo consta en el libro de Registro en ella custodiado.

En consecuencia está exento del servicio militar por Real decreto de diez y ocho de Enero de este año, guardado en el Archivo de esta Casa, y comunicado de Real orden á los Gobernadores de provincia por el Gobierno de S. M.

Y para los fines consiguientes le firmo la presente en la misma ciudad de Vich a once de Marzo de mil ochocientos.. J. C.P.

\section{APENDICE BIBLIOGRAFICO*}

ALCUBLlA, M., vide Martinez Alcubilla, M.

ARRANZ, J., Observaciones amigables en contestación al folleto: ¿A qué viene Monseñor Brunelli a España?, Madrid 1847.

BeLMAR, F. S., Observaciones al discurso que el Sr. Joaqutn Aguirre pronuncio el 9 del actual en el Congreso de Diputados sobre el último Concordato con la Santa Sede, Madrid 1860.

* Vide supra Introducción, 4- Fuentes y bibiografia. Algunos títulos son conocidos por noticias periodísticas, por ejemplo, La Esperanza, 16 de febrero 1857, unas Observaciones al Concordato de un sacerdote de Ciudad-Rodrigo. El tema del Concordato era muy frecuente en los perídicos. No he sabido encontrar referencias en, SEMINARIO DE BIBLIOGRAFía HISPANICA. FaculTad DE FLOSOFIA Y LeTras dE MADRID, Veinticuatros diarios (Madrid 1830-1900). Articulos y noticias de escritores españoles del siglo XIX, Madrid 1968-1975.

Hispania, del Mediterráneo al Atlántico

Hispania Sacra 51 (1999) 
BRAvo, J., El concilio de Trento y el Concordato vigente con las disposiciones dictadas para su ejecución, y la jurisprudencia del Consejo de Estado y Tribunal Supremo, Madrid 1887.

BROCH, P., El Concordato y el proyecto de asociaciones. Folleto de actualidad, Avila 1907.

BUTTRAGO Y HERNANDEZ, J., Las órdenes religiosas y los religiosos. Estudio jurídico sobre su existencia legal y capacidad civil en España, Madrid 1901.

CAnga Argütlles, J., El gobierno espahol en sus relaciones con la Santa Sede. Colección de documentos oficiales publicados antes y después del rompimiento de las relaciones. Texto literal del Concordato y articulos del periódico La Regeneración sobre estas materias, Madrid 1856.

Carramolno, Juan Martín, vide Martín Carramolino, J.

ClARET, A. M., «Concordato celebrado el año de 1851..», en Miscelánea interesante dada á luz por el Excmo. e llmo Sr. D.., Barcelona 1865, 201-279.

COMISION DE ESTADISTICA GENERAL DEL REINO, Anuario estadístico de España correspondiente á 1859 y 1860 publicado por la.., Madrid 1860.

Concordato celebrado en el año de 1851 entre SS. el Sumo Pontffice Pio IX, y S. M. Catolica Dona Isabel II, Reina de las Españas, Boletín Eclesiástico de la diócesis de Segovia, 18591860, el Concordato y documentos para su aplicación en pp. 1-256.

Concordato con la Santa Sede de 16 de marzo de 1851. Convenio adicional de 25 de agosto de 1859 y principales disposiciones concordadas sobre provisión de cargos del clero catedral y parroquial, Madrid 1910.

Concordato de 1851 analizado. Segunda edición, Cádiz 1875.

"Concordato de 1851", en Colección Legislativa comentada de materias eclesiasticas, 2(1866)186-219.

«Concordatos», en Diccionario jurídico-administrativo. Tomo I, Madrid 1858, 1461-1471.

«Concordatos», en Enciclopedia jurídica española. Tomo VIII, Barcelona 1910, 17-100.

CONGRESO DE LOS DiPUTADOS, Apuntes para el estudio del proyecto de ley regulando el ejercicio del derecho de asociación, presentado a las Cortes por el Sr. Ministro de la gobernación el día 25 de octubre de 1906. Tomo I (1810-1872). Tomo II (1876-1906). Apéndice legislaciones extranjeras acerca del derecho de asociación. Apuntes y textos legales, Madrid 1906.

CuCALON Y ESCOLANO, L., Exposición del Concordato de 1851.. insertándose ademas la parte reglamentaria expedida para la ejecución del vigente, Madrid 1853.

D. R. M. del C. presbítero, Observaciones crítico jurídico canónicas sobre los principales puntos contenidos en le Novisimo Concordato, haciendo ver la necesidad de su pronto y cabal cumplimiento, salvas aquellas variaciones que sean resultado de las negociaciones pendientes entre S. M. y la Santa Sede, Salamanca 1858.

De La Sota y Lastra, P., vide La Sota y Lastra, P. de

DORADO DE LA PEÑA, B., Estado jurtdico de los concordatos, Valladolid 1896.

Euo GaRAY, L., Apendices al escrito dirigido al Tribunal de Amigables Componedores sobre el Colegio Imperial de Madrid por el.. obispo de Madrid-Alcalá, Marzo 1926, s/a s/d.

EuIAS DE MOLINS, A., El Concordato de 1851 anotado con las teyes, decretos y disposiciones que se han publicado en su aclaración, Barcelona 1882.

España en la crisis actual. Nota-memoria. Presentación motivada en contra del Concordato.., Bruxelles 1850. 
Estadística del personal y vicisitudes de las Cortes y de los ministerios de España desde el 29 de septiembre de 1833 en que falleció el rey Don Femando VI, hasta el 24 de diciembre de 1879 en que se suspendieron las sesiones, Madrid 1880.

FORT, C. R., El concordato de 1851 comentado y seguido de un resumen de las disposiciones adoptadas por el Gobierno de S. M. .. hasta enero de 1853.. Segunda edición corregida y aumentada con la "Adición al Concordato» en 1859, Madrid 1859.

Garcia OCAÑa, J. M., El concordato, Razón y Fe, 10(1904)5-20, 514-522.

Garcia OchOA, M., Discutso leido en la Universidad Central. Exposición de los motivos y principales disposiciones del Concordato de 1851, Madrid 1861.

IGLESIAS, M., Discurso letdo por.. en el acto.. de recibir.. doctor en derecho civil y canónico. Exposición de motivos y principales disposiciones del Concordato de 1851, Madrid 1863.

LA SERna Y LA Fuente, A., de, Comentarios al Concordato entre el Sumo Pontffice Pto $L X$ y Su Majestad Católica Doña Isabel de Borbón, Madrid 1852.

LA SOTA Y LASTRA, P. de, Colección de escritos sobre materias eclesiasticas, Madrid 1871.

LAZARO GaRCIA, F., Concordato, bulas pontificias, reales ordenes, decretos e instrucciones emanadas de ambas potestades para el complemento y realización del mismo con la Santa Sede y el gobierno de S. M. C., con un indice para hallar con facilidad lo que se desea, recopilado todo por.., Segovia 1852.

MARques De Albaida, vide Orense y Milá de Aragón, J. M.,

MARTIN CARRAmolino, J., Elementos de derecho canónico con la disciplina particular de la Iglesia de España después de la publicación del Concordato de 1851, Madrid 1857.

Martinez AlCUBILla, M., Diccionario de la administración española. Cuarta edición, Madrid 1886, 779-902, con índice de los temas, Concordatos: culto y clero, asuntos eclesiásticos.

MAXIMO, vide Salcedo Ruiz, A.,

MINISTERIO DE GRACIA Y JUSTICIA, Guía del estado eclesiástico de España para el año de 1860. Madrid 1860.

MiNISTERIO de GRACIA Y JUSTICIA, Resumen de la Estadistica General Eclesiástica formada en el ... (Contiene todas las noticias importantes hasta el fin de 1859), Madrid 1860.

MoLiNS, E. de, El Concordato de 1851 anotado con las leyes, derechos y disposiciones que se han publicado en su aclaración, Barcelona 1882.

Montejo, J. de P., Hacienda pública. Propiedades del Estado. Desamortización civil y eclesiástica. I820 a 1918. Legislación vigente.. Indices, Madrid 1918.

ORENSE y MILA DE ARAGON, J. M., El Concordato. Por el autor del Folleto, ¿A qué viene el Sr. Brunelli?, Madrid 1847.

ORTIZ Y URRUELA, J. A., Observaciones sobre la revisión y reforma del Concordato, escritas con ocasión de un proyecto de ley que presentó a las Cortes Constituyentes D. Cristóbal Martín de Herrera, siendo ministro de Gracia y Justicia, Sevilla 1869.

P. V., Existencia legal de las corporaciones religiosas en España por.., Segunda edición, Madrid 1901.

PIÑUELA, E, et alii, El concordato de 1851 y disposiciones complementarias vigentes, Madid 1921.

PostiuS Y SALA, J., El código canónico aplicado a España en forma de instituciones.. Quinta edición refundida por el autor.., Madrid 1926.

Hispania, del Mediternáneo al Atlántico

Hispania Sacra 51 (1999) 
Pou y ORDINAS, A., J., Exposición de motivos y principales disposiciones del Concordato de 185I, Madrid 1866.

RAMON FORT, C., El Concordato de 1851, Madrid 1853.

SALCEDo RutZ, A., El anticlericalismo y las órdenes religiosas en España. Historia - crítica Derecho, Madrid 1908.

SANCHEZ RUBIO, J., Juicio imparcial y comentarios sobre el concordato de 1851 celebrado entre Su Santidad Pio IX y Su Majestad Católica la Reina de España Doña Isabel II, Madrid 1853.

Solis Y JoDRa, M de, Discurso sobre la naturaleza y caracter de los concordatos. Examen de los celebrados entre España y la Santa Sede, Madrid 1876.

TEJADA Y RAMIRO, J., Colección completa de concordatos españoles, Madrid 1862.

TERRON Y MELENDEZ, A., Opúsculo sobre la observancia del Concordato, restablecimiento de concilios espanioles y ereccion de la catedral en Madrid, Madrid 1865.

TORRES CAMPOS, M., Bibliografía española contemporánea del derecho y de la política con tres apéndices relativos a la bibliografia extranjera sobre el derecho español, a la HispanoAmericana y a la Portuguesa-Brasileña, Sevilla 1883.

TRONCOSO, J., El Concordato, o sea breves reflexiones polftico-religiosas sobre este importante documento, Madrid 1851.

VADILlo, J. M. de, Concordato de 1851 analizado. Segunda edición corregida y aumentada [la primera en 1851], Cádiz 1854.

Vizconde de Gracia Real vide La Serna y La Fuente, A. de, 